\title{
EDUCAR EM UM MUNDO DESERTO: A EDUCAÇÃO EM DIREITOS HUMANOS E O PENSAMENTO DE HANNAH ARENDT
}

Dissertação apresentada à banca examinadora da Faculdade de Direito da Universidade de São Paulo, como exigência parcial para obtenção do título de Mestre em Direito, sob orientação do Professor Doutor José Sérgio Fonseca de Carvalho.

FACULDADE DE DIREITO DA UNIVERSIDADE DE SÃO PAULO SÃO PAULO 


\section{FOLHA DE APROVAÇÃO}

BRUNIERA, Lincoln Coelho. Educar em um mundo deserto: a educação em direitos humanos e o pensamento de Hannah Arendt. Dissertação apresentada à Faculdade de Direito da Universidade de São Paulo para obtenção do título de Mestre em Direito. 2013.

Aprovado em:

Banca Examinadora

Prof. Dr. Instituição:

Julgamento Assinatura:

Prof. Dr. Instituição:

Julgamento Assinatura:

Prof. Dr. Instituição: Assinatura: 
Dedicado a pais e filhos, professores $e$ alunos. Especialmente aos meus. 


\section{AGRADECIMENTOS}

Agradeço primeiramente ao meu pai Amadeu Bruniera, fonte de inspiração para a realização deste trabalho, e à minha mãe Aparecida Coelho Bruniera, exemplo de pessoa e de companhia para se viver junto. A ambos agradeço por tudo que sou.

Agradeço também ao meu avô Oscar Orlando Bruniera e a minha avó Germínia Pondé Coelho por terem transmitido a mim precioso legado: amor e carinho.

Agradeço ao meu querido irmão Amadeu Coelho Bruniera por nossa jornada fraterna, reconhecendo-o como um dos principais incentivadores da realização deste projeto. Este empenho também é por ti e por tudo aquilo que vivemos.

Agradeço intensamente à minha companheira de todo sempre Andreia Fernandes de Ávila por ter feito a revisão final do texto e por ter dado todo apoio, incentivo e compreensão fundamentais à feitura da presente obra.

Agradeço aos meus filhos Hugo Ávila Bruniera e Gabriel Ávila Bruniera por terem me inspirado a continuar nesta empreitada e por terem me mostrado, diariamente, o que há de melhor: como é bom viver.

Agradeço a todos os amigos, funcionários, professores e alunos da Escola Estadual Dom Pedro I em São Miguel Paulista na cidade de São Paulo e, especialmente, aos professores Carlos Alberto Ferreira Tenreiro e Rosana Rosa pela amizade e cuidado que tiveram ao realizar a primeira revisão e a leitura crítica do trabalho.

Agradeço ao amigo Thiago Vaz pelos diálogos realizados sobre o assunto.

Agradeço aos funcionários, professores e alunos do programa de pós-graduação em Direitos Humanos (2010-2013) da Universidade de São Paulo e, especialmente, aos professores Guilherme Assis de Almeida, Flávia Schilling e Maria Victoria de Mesquita Benevides Soares por suas presenças e importantes contribuições dadas ao meu projeto de pesquisa na banca de qualificação, bem como àqueles que aceitarem compor a banca examinadora de minha dissertação.

Agradeço ao Programa Bolsa Mestrado da Secretaria da Educação do Estado de São Paulo pela bolsa concedida durante parte desta pesquisa. 
Agradeço ao Grupo de Estudos de Educação e Pensamento Contemporâneo da Faculdade de Educação da Universidade de São Paulo na pessoa de seus integrantes, amigos de discussão do pensamento arendtiano imprescindíveis à realização deste trabalho.

Agradeço, finalmente, ao meu orientador, José Sérgio Fonseca de Carvalho, pela generosidade, cuidadosa orientação e pelo feliz encontro nesse trajeto de escolher com quem vamos no mundo. Minha gratidão por tudo e meu profundo respeito à sua pessoa. 
A imaginação jamais pode dizer: é apenas isso.

Há sempre mais do que isso.

Gaston Bachelard, A poética do espaço. 


\section{RESUMO}

BRUNIERA, Lincoln Coelho. Educar em um mundo deserto: a educação em direitos humanos e o pensamento de Hannah Arendt. 2013. Dissertação apresentada à Faculdade de Direito da Universidade de São Paulo. São Paulo. 2013. O presente trabalho tem por objeto uma reflexão sobre a importância da educação e da vida pública na preservação e no cuidado com o mundo humano e comum. Iniciando com algumas questões que tangenciam diálogos de compreensão de nosso presente, realizamos uma abordagem sobre o legado deixado pelos antigos sobre o cosmos humano e a noção de mundo comum em Hannah Arendt, a partir do modelo da polis grega e da fundação romana. Em seguida, delineamos alguns aspectos da moderna negação do mundo e da noção de mundo deserto que nela se instaura e se expande especialmente com a ascensão do totalitarismo na Europa do século XX. No Epílogo da obra A Promessa da Política, Arendt apresenta um texto marcado pela metáfora do deserto, onde o que predomina é o nada e o ninguém, formulando alguns questionamentos acerca da moderna expansão da ausência de mundo que nos levam necessariamente para outras obras da autora, tais como A Condição Humana, Entre o Passado e o Futuro, Responsabilidade e Julgamento e As Origens do Totalitarismo. Esboçando alguns traços do que pode representar educar em um mundo deserto, buscamos, finalmente, realçar a importância de se realizar uma reflexão sobre o sentido da educação como formação para o viver comum. Como observa Arendt na obra Entre o Passado e o Futuro - um mundo comum - no qual decidimos, através da educação, se o amamos o bastante para salvá-lo da ruína, assumindo com isso a responsabilidade por ele. Educar em um mundo deserto pode representar uma importante contribuição no sentido de uma possível transformação da negação do mundo, metaforicamente delineada por Arendt como o mundo deserto, numa afirmação do mundo humano.

Palavras-chave: Mundo comum, deserto, educação, Hannah Arendt. 


\section{RIASSUNTO}

BRUNIERA, Lincoln Coelho. Educare in un mondo deserto: l'educazione ai diritti umani e il pensiero di Hannah Arendt. 2013. Dissertazione presentata alla Facoltà di Giurisprudenza, Università di San Paolo. San Paolo. 2013. Lo scopo di questo lavoro è una riflessione sulla importanza della formazione e della vita pubblica per la conservazione e la cura del mondo umano e comune. A partire da alcune questioni che dialoghi tangenti della nostra comprensione di questo, abbiamo condotto un imbarco sulla eredità lasciata dagli antichi sul cosmo e il mondo umano, del senso comune in Hannah Arendt, dal modello della polis greca e le fondazioni romane. Poi abbiamo delineare alcuni aspetti della moderna negazione del mondo e della nozione di mondo deserto che sia stabilito e si espande in particolare con l'aumento del totalitarismo del XX secolo in Europa. Nel Epilogo del libro La Promessa della Política, Arendt presenta un testo marcato dalla metafora del deserto, in cui ciò che prevale è niente e nessuno, formulando alcune domande circa l'espansione moderna della mancanza di mondo che ci portano necessariamente ad altre opere dell'autore, come La condizione umana, Tra passato e futuro, Responsabilità e giudizio e Le origini del totalitarismo. Delineare alcuni dei tratti che possono rappresentare educare in un mondo deserto, cerchiamo in definitiva sottolineare l'importanza di condurre una riflessione sul significato dell'istruzione e della formazione per vivere insieme. Come osserva Arendt nel libro Tra passato e futuro - un mondo comune - in cui abbiamo deciso, attraverso l'educazione, se amiamo abbastanza da salvarlo dalla rovina, portando con sé la responsabilità per questo. Educare in un mondo deserto, può rappresentare un importante contributo per una possibile trasformazione della negazione del mondo, metaforicamente descritto dalla Arendt come il mondo del deserto, l'affermazione del mondo umano.

Parole chiave: Mondo comune, deserto, educazione, Hannah Arendt. 


\section{SUMÁRIO}

INTRODUÇÃO. 10.

1. O DIÁLOGO DA COMPREENSÃO 15.

2. A NOÇÃO DE MUNDO COMUM EM HANNAH ARENDT: O MODELO DA POLIS ..........................................................................................

3. POLÍTICA E LIBERDADE NO ÂMBITO DA VIDA PÚBLICA..........46.

4. COM QUEM VAMOS? 61. 


\section{INTRODUÇÃO}

Como professor de filosofia na escola pública da rede estadual de São Paulo, pesquisador em direitos humanos na Faculdade de Direito do Largo São Francisco e integrante do Grupo de Estudos do Pensamento Contemporâneo na Faculdade de Educação da Universidade de São Paulo - no marco referencial de uma pesquisa que abrange questões que perpassam as esferas da arte, da política, da educação, do direito, da filosofia, da história, dentre outras - apresento aqui algumas considerações visando estabelecer diálogos de compreensão de um presente que tanjo ser não apenas meu, mas de muitos que vivem, viveram e viverão questões relacionadas à política, à formação, aos direitos humanos e ao mundo comum.

O presente trabalho tem por objeto uma reflexão que aborda essencialmente questões relacionadas à esfera da educação e da vida pública. A partir de nossas experiências vivenciadas no presente, o objetivo primordial será dialogar e refletir com autores que, de alguma forma, pensaram e atribuíram sentido a essas questões. Desses autores, a escolha fundamental foi dialogar especialmente com o pensamento de Hannah Arendt, a partir de inquietações sobre educação, política, mundo comum, bem como de negação do mundo, ampliando e aprofundando o conteúdo em estudo. É o que anunciamos no primeiro capítulo com os diálogos de compreensão que nos levam ao encontro de Arendt.

O que se pretende realizar é uma reflexão que procura ler alguns de seus textos a partir do que eles dizem, problematizá-los, questioná-los e criticá-los para ampliar o horizonte de nossas reflexões, inclusive no que se refere à educação, à formação e à vida pública em nossos dias. Essa pesquisa parte da leitura de seus textos, de seus comentadores e de autores que a influenciaram, de modo que seja possível construir uma reflexão que contribua para o pensamento em torno da educação e da vida pública, na preservação e no cuidado com o mundo comum e com os homens que nele convivem.

Desenvolver estudos e pesquisas com o intuito de enunciar questões que envolvem noções de autoridade e de responsabilidade, e que nos dão a pensar a formação humana e mundana, é o foco de referência. Hannah Arendt nos leva a pensar sobre a vida, os homens e o mundo. O que se pretende, portanto, é conhecer minimamente este solo em que se 
constitui o pensamento arendtiano e oferecer elementos que contribuam para compreender o sentido e a importância do educar e do viver em comum por intermédio da reflexão pautada em uma leitura crítica do objeto de pesquisa a ser investigado.

Esse parece ser o grande desafio para nós nesse início de século XXI e a educação em direitos humanos como formação para a vida pública pode contribuir e muito nessa tarefa de trilhar o caminho do cuidado com o mundo humano, especialmente no Brasil que vive um período de busca pela consolidação das estruturas democráticas e republicanas não apenas na condição de regime, mas também, na observação de Lefort, como existência social. É fundamental, portanto, pensarmos o presente, dialogando com referências importantes do passado, com vistas em nossas escolhas e, por assim dizer, no percurso a ser trilhado por nós mesmos a partir delas e, especialmente, em relação à realidade histórica, política, social, econômica e cultural. Com quem vamos? Quais são as nossas companhias no mundo? Nesse percurso, Arendt irá nos acompanhar com seus escritos.

O manuscrito original da obra As Origens do Totalitarismo terminado por Hannah Arendt em 1949, publicado pela primeira vez em 1951 e sofrido algumas revisões entre os anos de 1951 e 1973, constitui-se de três partes: Antissemitismo; Imperialismo; Totalitarismo. Nesta última parte há um texto de Arendt que trata da ideologia e do terror como uma nova forma de governo (totalitário) que acabou por abrir espaço para a expansão de um mundo deserto, lugar em que as pessoas são desprovidas de raízes, onde o que predomina é o nada e o ninguém, expande-se a ausência de um mundo humano, desaparece o espaço do 'entre nós' e, por que não dizer, desaparece o espaço público, isto é, o mundo comum. Desse modo, estabelece-se na sociedade de massa a impotência (incapacidade de agir) e a solidão (loneliness).

Eis a metáfora que surgiu a partir da leitura de um texto de Hannah Arendt, retirado de um curso intitulado A História da Teoria Política, ministrado pela autora em 1955, na Universidade de Berkeley, na Califórnia, e que aparece no Epílogo da obra A Promessa da Política: a metáfora do deserto. O que é isso denominado deserto pela autora? Que lugar é esse? Onde ele aparece e como se expande? Quando ele aparece e quando se expande? O que isso tem haver com o desaparecimento do espaço do 'entre nós', com o moderno desmantelamento do espaço público, com o predomínio da solidão (loneliness) e da impotência em tempos modernos? A expansão do deserto é uma questão política? É uma questão educacional? 
Neste texto, em especial, a noção de mundo deserto revela aspectos de enorme importância para se investigar questões fundamentais do pensamento político-filosófico arendtiano, levando-nos necessariamente a pesquisar outros traços de suas obras que aparecem especialmente em A Condição Humana, Entre o Passado e o Futuro e Responsabilidade e Julgamento, dentre outras, e que dizem respeito, inclusive, ao âmbito da moralidade e de nossas escolhas. Entretanto, não há possibilidade de se investigar e compreender a noção de mundo deserto em Arendt sem analisar inicialmente a noção de mundo comum no pensamento da autora: o que é o mundo comum em Arendt? A noção de mundo comum parece ter sido delineada a partir do modelo da polis grega. Como veremos no decorrer deste trabalho, não seria possível refletirmos sobre o sentido de mundo comum em Arendt, sem antes passarmos por uma abordagem de alguns aspectos da noção de mundo pautada na experiência dos antigos.

É o que faremos no segundo capítulo que apresenta preliminarmente considerações inspiradas em alguns estudos de Jaeger, Finley e Jean Pierre Vernant, dentre outros, acerca da formação da polis grega, a partir do século VIII e VII a.C., e que constituiu um acontecimento decisivo na história do pensamento político. Com base nesse ambiente fecundo à política, ressaltaremos a distinção realizada pela autora entre os domínios do público e do privado focados neste universo de organização da polis. Em seguida, esboçaremos algumas considerações pautadas no pensamento arendtiano acerca do sentido de mundo comum, que propicia enquanto lócus público, como artifício humano e palco das aparências, as condições de visibilidade daquilo que pode ser realizado por alguém, especialmente, através da ação e do discurso, e que pode permanecer na memória e ser lembrado.

Imersos nesse domínio comum que apresenta a pluralidade humana e a singularidade de cada novo ser que se insere no mundo humano como condição de toda vida política, ressaltaremos no terceiro capítulo a relação identificada por Arendt, no mundo comum, entre a política e a liberdade, bem como entre a arte e a política e a questão da imortalidade e o cuidado com o mundo, no qual, segundo os ensinamentos dos antigos, os homens teriam a possibilidade de realizar feitos imortais numa "vida boa" que transcende o mero viver num bem viver, num cuidar e preservar o mundo humano, política e culturalmente, no espaço do 'entre nós', e que pode deixar atrás de si, nas palavras de Arendt, "vestígios imorredouros" (ARENDT, 2010: 23). 
Com quem vamos? É a indagação que move basicamente a quarta e penúltima parte deste nosso trabalho. E como se pode perceber, nossa escolha foi estar em companhia de Hannah Arendt para realizar tais reflexões vislumbrando possibilidades de percorrer esse trajeto com o propósito de compreender a importância e o sentido de encontrar alguém e alguma coisa, isto é, um mundo comum em meio à moderna e expansiva ausência de mundo. É como se buscássemos encontrar alguma coisa e alguém (pessoa) em meio a um mundo deserto ou a possíveis tempestades de areia que, segundo Arendt, podem ameaçar ruir o mundo comum, palco de nossas aparições.

No último capítulo, buscamos problematizar a noção arendtiana de mundo deserto que aparece fortemente atrelada a eventos ocorridos na modernidade analisando o totalitarismo, metaforicamente delineado pela autora, como uma espécie de deserto em que o nada e o ninguém ameaçam destruir o mundo. Esboçaremos considerações acerca da moderna negação do mundo e da emergência da esfera social, da ideologia e do terror totalitário que marcam a época em que a autora viveu no século XX. Na parte que trata especialmente do totalitarismo, Arendt apresenta reflexões acerca da sociedade de massas, dos movimentos totalitários, do totalitarismo no poder e da ideologia e do terror, demonstrando que na vida pública e política a autoridade passa a não representar mais nada, tendo em vista que a violência e o terror exercidos pelos países totalitários nada têm a ver com autoridade. A responsabilidade pelo mundo é rejeitada e a autoridade tende a desaparecer.

Ausente a vida pública e política expande-se o processo de desertificação das pessoas e do mundo. Assim, o deserto é desarraigamento e superfluidade. Não ter raízes e "superfluir" é viver e se adaptar às modernas condições do deserto que nos levam à solidão (loneliness) e à incapacidade de agir. A solidão numa sociedade de massas e a violência do terror totalitário podem contribuir para a expansão deste mundo desarraigado e superfluido que representa uma ameaça a toda e qualquer forma de vida humana em comum e, neste sentido, a toda e qualquer forma de autoridade e responsabilidade pelo mundo, tais como as representadas por Arendt, por exemplo, na figura do educador.

Ressaltamos que Arendt, de maneira trágica e esperançosa, chama a atenção para o fato de que o moderno crescimento da ausência de mundo pode representar uma ameaça de sua destruição e, neste sentido, uma ameaça a toda e qualquer forma de autoridade e de responsabilidade pelo mundo. Todavia, a educação e a figura do educador junto aos novos 
que se inserem no mundo podem representar um caminho de criticidade, resistência e emancipação na medida em que possibilita significativamente uma formação humana para a vida pública e política.

É o que pretenderemos esboçar ao final da pesquisa ao tratar da educação e seus protagonistas, como um possível caminho rumo à resistência e à transformação do mundo deserto num mundo mais humano e comum. Neste sentido, destacaremos alguns exemplos de figuras que marcaram, cada um em sua época, a história da humanidade por trilharem esses caminhos. Como admiradora dos antigos, em especial de Sócrates, e como leitora crítica de diversos traços da modernidade, Arendt ressalta que o educador deve resistir a todo esse cenário de horror, desumanização e destruição que, em tempos modernos, assola o mundo, um educador que busca formar novos seres no mundo que, justamente pela singularidade e espontaneidade, podem representar o "milagre" do novo.

Arendt reconhece que não é tarefa fácil de ser realizada, vivida e imortalizada, pois são fronteiras que possibilitam aproximações e distanciamentos, fronteiras que expressam a marca trágica do pensar arendtiano que se propõe a aflorar ambiguidades, a dialogar com o mundo e silenciosamente consigo mesmo e a dizer o que pensa de forma singular como pessoa. Com base nos escritos de Arendt, podemos descrever a figura do educador como sendo alguém que tem a autoridade, a responsabilidade e a possibilidade de inserir os novos num mundo humano. Nessa perspectiva, o educador é aquele que deve cuidar da formação dessa coisa nova que vem ao mundo e que pode, em sua pluralidade humana, vir a ser alguém num mundo comum, não desértico, nem totalitário.

O educador tem a autoridade e a responsabilidade de formar novos seres humanos no mundo, "alguém" que possa resistir ao moderno e totalitário processo de desertificação, emancipar-se e realizar transformações, por obras, feitos e palavras, de modo a garantir o cuidado e a permanência de "alguma coisa", isto é, um mundo reificado e compartilhado na esfera da vida política. Nesse sentido, os mais velhos assumem uma significativa responsabilidade pelos mais novos na medida em que estes não têm familiaridade com o mundo, nas palavras de Arendt "deve-se cuidar para que essa coisa nova chegue à fruição em relação ao mundo como ele é” (ARENDT, 1990: 239). A permanência deste mundo comum reificado repousa, segundo Arendt, na natalidade e esta é a essência da educação. Educar em meio à moderna expansão do mundo deserto por amor ao mundo humano e comum. Eis a questão. 


\title{
1. O DIÁLOGO DA COMPREENSÃO
}

\author{
Quando entrar setembro \\ E a boa nova andar nos campos \\ Quero ver brotar o perdão \\ Onde a gente plantou \\ Juntos outra vez. \\ Já sonhamos juntos \\ Semeando as canções no vento \\ Quero ver crescer nossa voz \\ No que falta sonhar \\ Já choramos muito \\ Muitos se perderam no caminho \\ Mesmo assim não custa inventar \\ Uma nova canção \\ Que venha nos trazer \\ Sol de primavera \\ Abre as janelas do meu peito \\ A lição sabemos de cor \\ Só nos resta aprender \\ Beto Guedes/Ronaldo Bastos ${ }^{1}$
}

Numa entrevista para um canal de televisão no início dos anos 1980, o músico Beto Guedes, compositor da música Sol de Primavera, dá-nos um breve panorama do contexto histórico-político e cultural, no qual vivíamos um período de transição na história política de nosso país, de um sombrio, violento e conturbado regime militar ditatorial para um novo, esperançoso e sonhado processo de democratização no Brasil. A respeito da importância da formação, da manifestação cultural e da aparição de uma nova palavra, bem como de uma nova música que falasse abertamente e superasse, por assim dizer, a necessidade de termos de nos manifestar culturalmente por meio de metáforas, dizia o artista:

O governo é que sempre atrapalha todo mundo, né? Eles estão em cima e eles estão sempre atrapalhando e deixando as pessoas cada vez (em todos os setores, na arte ou no trabalho, em todo tipo de trabalho), eles estão em cima sempre dificultando todo o barato. A música estava indo para um

\footnotetext{
${ }^{1}$ Sol de Primavera. Música composta em 1979 e lançada no CD "Dias de Paz" do cantor e compositor Beto Guedes em 1998.
} 
caminho muito oprimido, as pessoas tinham que dizer sempre meias palavras, entendeu? Isso eu acho que realmente aconteceu ${ }^{2}$.

Refletir sobre a arte e a política como fenômenos da vida pública remete-me inevitavelmente à minha infância e aos duros anos que findavam a ditadura militar no Brasil, especialmente no período de 1975-1985. Neste contexto histórico, político e cultural do nosso país, eu que vivia a minha infância, obviamente sem conhecer as reflexões de Hannah Arendt, sentia na arte um instrumento que dizia algo, um fenômeno do mundo público que dialogava com a política e que, fundamentalmente, dizia algo sobre o/ao mundo, e que dizia algo sobre e/a mim, especialmente quando eu olhava a minha volta, trazendo esperanças de um futuro diferente daquele período no qual vivíamos a ditadura militar. Hoje, passados mais de vinte e cinco anos, e lendo Arendt, compreendo melhor o que senti. Em nossos dias surgem novas questões, tais como: o que mudou em nosso contexto histórico-político atual em relação aos duros anos do militarismo? O que ainda não mudou? O que precisamos criar em termos de democracia no Brasil para que ela se amplie em nossa sociedade e instituições?

O termo compreender aqui aparece num sentido muito próximo ao compreender arendtiano e às manifestas dificuldades da compreensão. A compreensão, dizia Arendt, começa com o nascimento e termina com a morte, é uma atividade interminável por meio da qual nós tentamos sentir o mundo como nossa casa, sentir-se conciliado com ele. Compreender é a maneira especificamente humana de viver. Arendt articula sua formação filosófica à reflexão política do seu tempo: o século $\mathrm{XX}$. No ensaio Compreensão $e$ política esse sentido do compreender e as dificuldades da compreensão aparecem de forma latente. Compreender o totalitarismo não é desculpar nada, mas nos conciliar com um mundo onde tais coisas são possíveis (ARENDT, 2008: 331).

No trecho de encerramento deste ensaio, Arendt escreve:

somente a imaginação permite que enxerguemos as coisas em sua perspectiva adequada, que tenhamos forças suficientes para afastar o que está demasiado próximo, a fim de conseguir ver e compreender sem distorções nem preconceitos, que tenhamos generosidade suficiente para transpor abismos de lonjuras, a fim de conseguir ver e compreender,

\footnotetext{
${ }^{2}$ O músico, em entrevista concedida a TV Manchete no início dos anos 1980 no Brasil, refere-se aos duros anos da ditadura militar brasileira.
} 
como se fosse uma questão pessoal nossa, tudo o que está demasiado distante de nós. Esse distanciamento de algumas coisas e avizinhamento de outras faz parte do diálogo da compreensão, pois para suas finalidades, a experiência direta envolve um contato próximo demais e o mero conhecimento ergue barreiras artificiais. Sem esse tipo de imaginação, que de fato é a compreensão, nunca seríamos capazes de marcar nossas referências no mundo. É a única bússola interna que dispomos. Somos contemporâneos na exata medida do alcance de nossa compreensão. Se quisermos superar o estranhamento e ter uma moradia neste mundo, mesmo ao preço de adotar como lar este nosso século, temos de tentar participar do interminável diálogo com a essência do totalitarismo (ARENDT, 2008: 346).

Na década de 80, lembro-me, por exemplo, de ter escutado diversas vezes os versos de Bertold Brecht: Hay hombres que luchan um dia y son Buenos. Hay otros que luchan um año y son mejores. Hay quienes luchan muchos años y son muy Buenos. Pero hay los que luchan toda la vida: Esos son los imprescindibles. ${ }^{3}$ - declamados nesta língua e pela voz de Mercedes Sosa, como introdução a uma música denominada Sueño com serpientes que ela cantava juntamente com Milton Nascimento. Era belíssimo, trazia esperanças, a mensagem que devia permanecer; dizia algo sobre o mundo que precisávamos ouvir, que fazia sentido no contexto histórico-político e cultural no qual vivíamos e eu, enquanto criança, simplesmente gostava daquilo, pois tal experiência estética representava a possibilidade de um juízo sobre o mundo no qual estava inserido, especialmente na América Latina e no Brasil da ditadura militar, e o qual eu condenava desde a mais tenra infância por não gostar do que via e vivia.

As experiências estéticas, as manifestações culturais e sociais, os exemplos vistos, vividos e sofridos são inúmeros na história recente de nossa sociedade antidemocrática marcada pelo autoritarismo, pela violência de um regime militar ditatorial que nos privava de muitas liberdades, de muitos direitos e da criação de novos. Temos uma vasta bibliografia e um grande acervo histórico-cultural nacional que retrata parte dessa nossa triste história de expansão de um mundo desértico à moda brasileira que foi a ditadura militar de 1964-1985, tais como o Arquivo do Estado de São Paulo, o Relatório Brasil nunca-mais da Comissão Justiça e Paz de São Paulo, dentre muitos outros. Neles podemos ter uma pequena noção da quantidade de pessoas que foram desaparecidas,

\footnotetext{
${ }^{3}$ Há homens que lutam um dia e são Bons. Há outros que lutam um ano e são melhores. Há os que lutam muitos anos e são muito Bons. Porém há os que lutam toda a vida: Esses são os imprescindíveis. Fragmento extraído do álbum Sentinela, de Milton Nascimento, pela gravadora Ariola, 1980.
} 
presas, torturadas, mortas, que tiveram inúmeros direitos e liberdades violados durante o período da implantação e consolidação do regime militar autoritário no Brasil.

A repressão política e sociocultural imposta pela ditadura buscava nos privar da possibilidade de exercermos livremente o pensar, o falar, o agir e o manifestar de nossas opiniões em público. Paradoxalmente, levava muitas pessoas resistentes ao regime a buscar sem medir esforços, corajosamente, a efetivação de uma sociedade mais livre, igual, justa e democrática no Brasil. A Constituição Federal de 1988 elucida esse anseio do povo brasileiro pela concretização da democracia em nosso país, em seus mais diversos dispositivos constitucionais que propõem a garantia de direitos fundamentais, dentre os quais a liberdade de pensamento, de expressão e de opinião.

Um exemplo bastante singular e próximo em nossas vidas - embora tenha acontecido similarmente com muitas outras pessoas que viviam em nosso país no contexto da ditadura militar brasileira e que, de certa forma, perpassa questões que envolvem as esferas da vida, da política, da formação humana, dos direitos humanos (ou da ausência deles), dentre tantas outras coisas - é o da subversão. Pessoas próximas e distantes, no auge do regime militar eram tidas como subversivas pelo Estado brasileiro, tendo sido presas, desaparecidas, torturadas e mortas nos porões da ditadura.

Há inúmeros documentos nos arquivos do DOPS (Departamento de Ordem Política e Social) e do DOI-CODI (Destacamento de Operações de Informações - Centro de Operações de Defesa Interna), que demonstram isso. Prisões indevidas, torturas, mortes e desaparecimentos eram correntes nesse período com 'fundamento' no combate aos subversivos que representavam uma ameaça ao regime militar. Ser subversivo em nosso país significava para o regime militar ser inimigo da pátria, um perigo e uma ameaça ao povo brasileiro. Essa era a doutrinação. Nas escolas, embora tivéssemos professores (e outros profissionais da educação) que viviam à margem desse processo ideológico de dominação e de terror ditatorial, resistentes e críticos ao regime, aprendíamos isso oficialmente como uma verdade irrefutável e inquestionável que, na realidade, obscurecia a imprescindível transparência das instituições, dos espaços públicos e das pessoas que buscavam conviver em tais espaços com certa dignidade.

Ao serem introduzidas essas "verdades" como temas de nossas discussões, o que acontecia era que na realidade éramos desinformados pelas instituições, dentre as quais a própria escola. Essa doutrinação distorcia a nossa compreensão do mundo no qual 
vivíamos. Uma professora que lecionava em tal contexto nos conta que, nas escolas, todos os anos, no dia 31 de março, os professores eram convocados a descer com seus alunos até o pátio para a comemoração do dia cívico do golpe militar, considerado por muitos o dia da "revolução", todos convidados a falar em defesa do regime. Alguns professores resistentes à ditadura se recusavam a participar disso como um evento comemorativo, denunciando e dialogando com seus alunos a opressão do regime.

A partir de 1968 expandia-se a propaganda e a ideologia do regime militar, instrumentalizadas pela violência e pelo terror, cuja opacidade violenta no Brasil com o governo de Emílio Garrastazu Médici, em que os famosos "porões da ditadura" ganhavam força e apoio do Estado, promoviam prisões arbitrárias, torturas, mortes e desaparecimentos. Num certo sentido, a descartabilidade humana, termo utilizado por Arendt para expressar o que ocorrera durante o totalitarismo na Europa, crescia por aqui juntamente com a expansão do uso da força e da violência pelo regime autoritário que marcou este período conhecido como uma "página negra da nossa história". Nesse período, muitos foram para fora do país, muitos que por aqui ficaram sofreram pela repressão também. Era preciso oprimir a subversão e todos aqueles que representassem uma ameaça ao regime, nem que para isso se mentisse, prendesse, torturasse e matasse dentro, ou mesmo fora, dos porões.

O que se nos passava nas escolas, nas ruas, meios de comunicação e sociedade em geral que apoiava o regime, era que, em poucas palavras, pessoas próximas e distantes, tidas como subversivas pelo Estado, eram um perigo, uma ameaça a todos, inclusive a cada um de nós. E isso me fazia pensar desde muito cedo sobre o que era esse mundo e o que fazer dentro dele, pois uma das poucas certezas que tinha era que tais pessoas, especialmente as mais próximas e conhecidas, não eram inimigas de todos, não representavam uma ameaça e um perigo à pátria, tampouco a mim. Resistentes e críticas ao regime, os grandes exemplos deixados por essas pessoas sempre fora os de mostrar outras possibilidades que não aquela desértica experiência da ditadura militar instaurada no Brasil. Incentivavam-nos, contrariamente, a questionar, a refletir, a dar importância ao diálogo, à vida comum; a lutar pela democracia e por uma conscientização política emancipadora; a respeitar a pluralidade humana e de ideias, a formação crítica ante os ditames do regime autoritário e violento; a ressaltar a importância do contraditório na construção da vida comum, da coisa pública, da democracia, dos direitos humanos e do Estado Democrático de Direito. Isso certamente não representava uma ameaça a todos, mas 
talvez àqueles que tinham interesse na manutenção de um regime violento e ditatorial que fora instaurado no Brasil desde meados da década de 60 e que impunha-nos uma negação radical da igualdade, da liberdade, da solidariedade, da criatividade, dos direitos fundamentais da pessoa humana, dos direitos sociais, econômicos, políticos, culturais e da criação de novos direitos.

À luz do que foi dito, trago registros do documentário Travessia (2009) de João Batista de Andrade, que trata de forma significativa questões relacionadas a tal contexto histórico-político nacional, com diversos depoimentos de pessoas que viveram a experiência do regime militar. Somando-se a isso, há especialmente a memória de conversas, outros documentários, livros, pesquisas acadêmicas, arquivos, recortes de jornais, depoimentos de artistas, registros de nossos movimentos sociais e culturais, além de muitas aulas de professores resistentes ao regime militar que buscaram dar conta de nos contar parte daquilo que aconteceu na história de nosso país em tal contexto ${ }^{4}$.

Rever, sofrer e reviver experiências violentas e autoritárias em nossos dias é como sentir a ameaça constante do retorno daquelas terríveis tempestades de areia que assolaram e obscureceram nosso país com a expansão de um deserto à moda brasileira em tempos de ditadura. Por isso, é fundamental que atribuamos sentido a tudo isso e que tenhamos a coragem de resistir, julgar, condenar e dizer ao mundo que tais experiências não são boas e não devem estar em nossa companhia, embora vivamos num mundo em que tais coisas podem acontecer e de fato aconteceram. Como já mencionado, um dos caminhos para a realização dessa tarefa é, indubitavelmente, a afirmação dos direitos humanos e da educação em direitos humanos como algo fundamental à formação humana para a vida pública em nosso país.

A importância política da verdade factual, como observou Celso Lafer ao analisar a obra de Arendt,

\footnotetext{
${ }^{4}$ Como estudante de filosofia na Universidade de São Paulo lembro-me, por exemplo, das aulas do Professor Paulo Eduardo Arantes. Estudávamos na década de 1990 algumas obras de autores brasileiros com o intuito de entrarmos em contato com exemplos que fizeram parte da nossa história e que poderiam nos propiciar a possibilidade de reconhecer alguma coisa de outro lugar, de construir possibilidades de se pensar a partir da nossa própria realidade histórica e política. Dentre elas, cito especialmente algumas que nos marcaram, Departamento de Filosofia: Um Departamento Francês de Ultramar de Paulo Arantes; Vida Comum e Ceticismo de Oswaldo Porchat e Cinema: uma trajetória no subdesenvolvimento de Paulo Emílio Salles Gomes.
} 
adquire relevância adicional no que tange ao alcance e a justiça da relação entre narrativa e testemunho. Só se lida a posteriori e apropriadamente com as consequências de dark times, como aponta Hannah Arendt no seu ensaio sobre a escritora Isak Dinensen, narrando o que se passou. As dores podem ser suportadas, se postas numa "história" que revela o alcance do que ocorreu, que do contrário, permanece como uma sequência intolerável de meros acontecimentos. Neste contexto da dor, a relação entre ação, estória e história realçada por Paul Ricoer na sua análise de The Human Condition, explicita-se no contar (LAFER, 2003: 167).

Os "tempos sombrios" do período autoritário à moda brasileira eram uma manifesta negação, do "direito a ter direitos" 5 , da criação de novos direitos e da possibilidade de realizarmos a ampliação da democracia no Brasil, não apenas como um regime político, mas como forma de sociedade. A violência começa onde termina o discurso (logos); onde a violência impera, a democracia se esvai. Como nos ensina a experiência democrática grega, se não há debate, publicidade e isonomia, não há mundo comum. Para Hannah Arendt, o poder e a violência se configuram como termos opostos, a afirmação absoluta de um significa a ausência e a negação do outro. A violência representa uma ameaça de destruição do poder, algo similar ao vivenciado no Brasil da ditadura.

A atualidade do legado deixado por Arendt, intérprete do nosso tempo, é notória e fundamental para compreendermos o nosso próprio presente no Brasil, marcado pela violência e terror, pela negação de direitos e privação de liberdades, pela utilização propagandística de um governo autoritário que impunha a homogeneização social, pelo esmagamento dos direitos e liberdades, pela sufocação da palavra, pela descartabilidade humana e burocratização da vida pública, dentre muitos outros dilemas que ainda hoje enfrentamos em tempos de democracia, e que respingam com a força de tempestades de areia na vida pública e política do nosso país. E tais dilemas devem ser compreendidos na medida em que desejamos a ampliação da democracia.

Como observa Arendt, o processo de compreensão também é de autocompreensão, "pois, se apenas sabemos, mas ainda não compreendemos, contra o que estamos lutando, por outro lado não sabemos nem compreendemos muito bem em favor do que estamos lutando" (2008: 346). Neste sentido, a atividade de compreender que é

\footnotetext{
${ }^{5}$ Noção arendtiana fundamental à garantia, proteção e preservação da dignidade humana, construído à luz e às sombras dos regimes totalitários implementados na Europa do século XX. Arendt fora juridicamente reconhecida como uma apátrida até 1951, quando finalmente adquiriu a cidadania norte-americana. Sua obra de certa forma preanuncia muito do que irá ocorrer no Brasil com a ditadura militar. Em especial a metáfora do deserto, onde predomina o nada e o ninguém, que aludiremos mais adiante em nosso trabalho.
} 
necessária apresenta-se como sendo "a única que pode conferir significado e gestar uma nova desenvoltura para o espírito e o coração humano" (2008: 346).

São questões que nos possibilitam estabelecer constantes diálogos com o pensamento de Arendt com vistas a buscarmos compreender o nosso próprio presente no Brasil, especialmente o ora fundado no Estado Democrático de Direito sob a égide de nossa Constituição Federal de 1988 emanada do povo e declaradamente defensora da res pública, do agir em conjunto, da democracia e dos valores pautados nos direitos humanos, dentre os quais, o combate a toda e qualquer forma de opressão e violência. É neste sentido que entendemos que os direitos humanos como uma formação para a vida pública e política, pode representar uma resposta carregada de sentido ao processo de desertificação à moda brasileira vivida durante os duros anos da ditadura militar e que ainda se vive em nossos dias quando a violência, o autoritarismo, a vontade de dominação, o privilégio em benefício de alguns, ameaça destruir a vida e o mundo comum, fundado sob os pilares da palavra, da igualdade e da publicidade: isto é da democracia ${ }^{6}$. A formação humana e os direitos humanos como uma formação para a vida pública e política assume importante papel na ampliação de nossa república no sentido de se buscar uma existência social mais livre, igual, justa, comum não apenas enquanto princípios e regime político, mas como algo concreto na vida de todos, no viver junto ${ }^{7}$.

As características desérticas, os ranços, as traças e as pragas que fizeram parte da nossa obscura história da ditadura militar no Brasil devem ser levadas em conta, compreendidas na sua manifesta incompreensão. E nas suas manifestas dificuldades de compreensão, no sentido arendtiano do termo, elas devem ser compreendidas (imaginadas) de modo que possamos ter a possibilidade de marcar as nossas referências no mundo, superarmos nosso estranhamento e termos uma morada nele (e que se diminua o risco de ser destruída pela ausência-de-mundo, representada pela violência, pelo terror, pelo totalitarismo, pelo desejo de poder a qualquer custo), que possamos "pescar pérolas",

\footnotetext{
${ }^{6}$ Como observa José Sérgio F. de Carvalho "a ampliação do caráter democrático de uma sociedade depende de uma cultura de respeito e promoção de condutas guiadas pelos valores pautados nos direitos humanos e, para essa transformação, a melhoria da ação educativa escolar é fundamental. Esta por sua vez depende da promoção de ações institucionais guiadas por esses valores." Direitos humanos e educação - Educação e Direitos Humanos: formação de professores e prática escolares. Ética e cidadania - Construindo Valores na Escola e na Sociedade. Ministério da Educação. 2007.

${ }^{7}$ Há um artigo do Professor Franklin Leopoldo e Silva denominado Viver junto que chama a nossa atenção para a importância disso. Revista SESC - agosto 2010
} 
fragmentos, fazer insurgir o franco falar, a coragem da verdade ${ }^{8}$, novas palavras que redescubram e redefinam o sentido e a importância do novo, do "direito a ter direitos", da criação de novos direitos e de um mundo mais igual, livre, justo, plural, democrático, humano e, nas palavras de Arendt, comum.

O filósofo francês Claude Lefort, crítico radical dos regimes autoritários e totalitários do século XX, chama a nossa atenção para a importância de se pensar e se viver a democracia numa perspectiva existencial de permanente conflito num feitio não totalitário, e os direitos humanos, numa dimensão simbólica, como uma questão política de primeira categoria na configuração de uma existência social democrática, de um viver comum capaz de impor limites às experiências totalitárias e autoritárias do nosso presente. Esse sentido político dos direitos humanos como formação para a vida pública que se manifesta expressamente dizendo não à violência, à discriminação, ao totalitarismo e ao terror, dentre tantas outras coisas, e que diz sim ao exercício da política, ao debate contraditório, à publicidade, à igualdade, à dignidade humana, ao direito a ter direitos, à realização de uma existência social democrática numa perspectiva de permanente conflito, na qual o que a define é justamente a impossibilidade da eliminação de seus conflitos, instiga-nos a realizar esse trabalho e a refletir sobre os direitos humanos e o seu caráter político como formação para a vida pública em que, segundo Lefort, temos a possibilidade de produzir o exercício de direitos e a invenção de novos direitos ${ }^{9}$, numa perspectiva democrática que consolida e que garante direitos e liberdades no sentido de um viver comum. Em política não existem soluções definitivas, numa perspectiva de permanente conflito pode apenas propiciar abertura ao tempo histórico, no qual podemos realizar invenções democráticas.

Segundo Marilena Chauí, na apresentação do livro A invenção Democrática Os limites da dominação totalitária, publicado pela primeira vez no Brasil em 1981, no contexto histórico-político nacional no qual a democracia tinha se tornado o centro dos debates e das ações políticas, com Lefort outra ideia da democracia se tornou possível:

\footnotetext{
${ }^{8}$ Em referência ao governo de si e dos outros de Michael Foucault, especialmente a parte que trata da figura de Sócrates. FOUCAULT, Michel. O governo de si e dos outros: curso no Collège de France (1982-1983). Tradução Eduardo Brandão. São Paulo: Editora WMF Martins Fontes. 2010.

${ }^{9}$ Há um trabalho interessante denominado Michel Foucault e o Direito de Marcio Alves da Fonseca, pela Editora Saraiva, 2012, especialmente o último capítulo do livro que fala da possibilidade de caminharmos em busca de um direito novo.
} 
Entendida como invenção histórica (invenção porque sem modelos a seguir) e como forma da existência social (e não apenas regime político), a democracia é pensada como única formação política em que o poder não se confunde com o governante, permanecendo com a sociedade soberana, que não oculta as divisões sociais e suas lutas, mas considera o conflito legítimo, e cujo cerne é a contínua criação de direitos sociais, econômicos, políticos e culturais pela ação dos sujeitos sociais e políticos (2011).

A formação humana assume um importante papel no nosso percurso histórico, social, político, econômico, cultural com vistas à vivência de uma experiência democrática autêntica. Nosso desafio é democratizar não apenas o nosso sistema político, mas a economia, educação, memória, direitos, liberdades, culturas, que possamos realizar concretamente um modo de existência social democrática. A educação como uma formação humana para a vida pública e política pode contribuir para que isso se torne possível. E os direitos humanos como formação e afirmação do caráter público e político pode contribuir significativamente para a ampliação do caráter democrático de nossa sociedade, segundo Lefort, na impossibilidade da eliminação definitiva de seus conflitos, não apenas enquanto regime político, mas também como forma de sociedade numa perspectiva de resistência a todo e qualquer processo de dominação totalitária do mundo e das pessoas que nele convivem (opressão, violência, terror, autoritarismo, discriminação, desigualdade, privilégio, dentre outros), bem como de preservação e renovação de um mundo comum no sentido arendtiano do termo. Para tanto precisamos refletir, questionar, dialogar, compreender, formar, agir, cultivando o respeito, a defesa, a promoção e a proteção dos direitos humanos e do viver comum. E o caminho para isso é a formação humana que passa por uma tarefa educativa.

Para compreendermos o sentido dessa tarefa, e a responsabilidade que temos de abraçá-la para que ela permaneça em nossa companhia, é fundamental que estabeleçamos um permanente diálogo de compreensão do nosso presente, entre o passado e o futuro, de nossas histórias, do que veio e do que está por vir, de fragmentos e pérolas pescadas, como dizia Walter Benjamin, do parecer ser e do parecer não ser da democracia e de suas indeterminações, da uniformidade do totalitarismo, de alguma coisa, de nada, de alguém, de ninguém, do mundo e da ausência dele. Como observa Arendt, a compreensão é um processo complexo que nunca gera resultados inequívocos, “é uma atividade interminável por meio da qual, em constante mudança e variação, chegamos a um acordo e a uma 
conciliação com a realidade, isto é, tentamos sentir o mundo como nossa casa" (ARENDT, 2008: 330).

É o que pretenderemos realizar a seguir, amparados especialmente no pensamento político de Hannah Arendt sobre a noção de mundo comum e de mundodeserto, na medida em que tais coisas são possíveis, pois

compreender é infindável e, portanto, não pode gerar resultados definitivos. É a maneira especificamente humana de viver, pois todo indivíduo precisa se sentir conciliado com um mundo onde nasceu como estranho e onde sempre permanece como estranho, na medida de sua singularidade única. A compreensão começa com o nascimento e termina com a morte. Na medida em que o surgimento dos governos totalitários é o acontecimento central de nosso mundo, compreender o totalitarismo não é desculpar nada, mas nos conciliar com um mundo onde tais coisas são possíveis (ARENDT, 2008: 331). 


\title{
2. A NOÇÃO DE MUNDO COMUM EM HANNAH ARENDT: O MODELO DA POLIS.
}

\author{
Meu coração sambeia \\ E estica esteira procê passar \\ Céu que te presenteia \\ E estica esteira procê passar
}

Jardel Caetano e Zé Modesto ${ }^{10}$

Céu, sob qual céu, queremos viver? E o que pode ele nos presentear? A música Esteira nos inspira possibilidades, sugerindo-nos caminhos não solitários, mas comuns, compartilhados, plurais e humanos. Céu que te presenteia, coração sambeia: estica esteira procê passar, esteticamente, intensifica-se aqui o gosto por nos mostrar a importância do outro em nossas experiências e vivências num mundo no qual queremos viver. Viver e viver bem parecem ser escolhas por trilhar caminhos que julgam por bem esticar esteiras para que o outro (alguém) possa passar. Pela poética, como esticar esteiras e abraçar essa nossa humana condição?

Em A fragilidade da bondade: fortuna e ética na tragédia e na filosofia grega, Martha C. Nussbaum (2009) realça a questão da vulnerabilidade humana em torno da fortuna e de como os pensadores gregos antigos acreditam que temos possibilidade de humanamente viver. Como é possível viver uma vida humana boa, de certa maneira apropriadamente autossuficiente (não apenas no âmbito da razão, mas também das nossas emoções, percepções, sentimentos), que não seja imune às incursões da fortuna, pois frágil e vulnerável?

O termo autossuficiente aparece aqui como algo que reconhece e atribui valor às coisas frágeis e vulneráveis da boa vida humana: bens relacionais, como observa Nussbaum. Uma autossuficiência do tipo comunal (Aristóteles), que caracteriza a melhor

\footnotetext{
${ }^{10}$ Trecho da música Esteira, lançada no CD Xiló, pelo selo Dançapé, com distribuição da Tratore 2008.
} 
vida humana, reconhece as relações sócio-políticas e a philía como partes essenciais e valiosas da boa vida e estipula que uma vida solitária é insuficiente para a eudaimonía. Segundo Nussbaum, argumentando contrariamente a defesa da autossuficiência solitária, Aristóteles ressalta que

esses relacionamentos vulneráveis e suas atividades associadas têm tanto valor instrumental como meios necessários, quanto valor intrínseco como partes componentes da melhor vida humana. No entanto, argumenta ele, isso não coloca a melhor vida intoleravelmente à mercê da fortuna. Pois é possível realizar cada um desses valores, propriamente compreendidos, no interior de uma vida que não é intoleravelmente instável, que possui um tipo apropriadamente humano de autossuficiência (NUSSBAUM, 2009: 301).

Ressalta ainda,

entre os bens humanos estimados, a qualidade de membro e a boa atividade em uma comunidade política são excepcionalmente vulneráveis ao revés do acaso. Sequer é preciso mencioná-lo. As tragédias sobre as quais Aristóteles e sua plateia foram educados, e sobre as quais ele deseja educar os jovens cidadãos, centram-se em temas de derrota na guerra, escravidão e perda do exercício político e da liberdade política. Os tempos de Aristóteles eram tempos de alarmante instabilidade política. Sua própria vida foi um exemplo dessas incertezas (NUSSBAUM, 2009: 301).

Em face da fragilidade da vida política e ciente das defesas filosóficas da boa vida solitária (Platão), Aristóteles se recusa a tomar esse caminho, sugerindo, diferentemente, uma autossuficiência do tipo comunal que, neste sentido, não se afasta da vida política. Numa acepção voltada para a experiência do mundo grego antigo, Nussbaum apresentanos uma versão, expressa e defendida por Aristóteles, que ressalta e satisfaz as nossas intuições práticas mais profundas sobre a relação apropriada com a fortuna para um ser humano que pode ver certos valores, tais como a boa vida ao lado de amigos, pessoas amadas e a comunidade, a confiança depositada no mutável e instável, intelecto como água corrente, dado e recebido. E neste sentido, viver bem num mundo em que o externo tem poder, risco, conflito, que realça a vulnerabilidade, a fragilidade da boa vida.

Como observa Nussbaum, 
um retrato da excelência que nos é mostrado na tradicional imagem da areté como planta: um tipo de valor humano inseparável da vulnerabilidade, uma excelência que é em sua natureza relacionada ao exterior e ao social, uma racionalidade cuja natureza não se deve tentar capturar, agarrar, prender em armadilha e controlar, em cujos valores a abertura, a receptividade e o fascínio desempenham uma parte importante (NUSSBAUM, 2009: 18).

Noutras palavras, em face da vulnerabilidade da boa vida e da fragilidade da bondade que nos são apresentadas especialmente em peças trágicas sobre as experiências vividas e sofridas humanamente ${ }^{11}$, como observa Nussbaum, quem pensamos ser, e onde (sob qual céu) queremos viver? Daí nossas questões iniciais, sob qual céu queremos viver? E o que pode ele nos presentear? Na medida em que as pensamos em sua relação intrínseca com o sentido de se compreender a importância de se viver uma vida boa plena, pautada na experiência dos gregos antigos, nas palavras desta autora, uma vida humana boa (frágil, vulnerável), que tem possibilidades de se realizar, por exemplo, na atividade e no compromisso político vivido num ambiente fecundo ao que nos é comum e que se distingue da esfera do privado, do domínio de interesse particulares e pessoais.

Algo que nos apresenta perspectivas de certo modo diferentes das experiências vivenciadas em tempos modernos caracterizados fundamentalmente por uma esfera social, isto é, pela falta de distinção entre as esferas do público e do privado, em larga medida que se sobrepujam os interesses privados (majoritariamente econômicos) acima dos interesses públicos e comuns e que, justamente por isso, podem nos servir de exemplo a ser pensado em nosso presente, em como vivermos humanamente melhor as nossas vidas, os nossos caminhos e esteiras e o quanto é fundamental reconhecermos a importância do outro para que essa condição ocorra.

Nossas experiências, especialmente nas décadas 60, 70 e início dos anos 80 do século passado, dão conta que a repressão política, o autoritarismo, a violência, o terror de um regime ditatorial que tem em seu cerne a descartabilidade humana e o privilégio em proveito de alguns em detrimento de muitos, são condições vividas, sofridas e conhecidas na história política nacional e que parecem ecoar até os nossos dias, embora atualmente

\footnotetext{
${ }^{11}$ As tragédias gregas de Ésquilo, Eurípides e Sófocles são exemplos disso, pois concebem a melhor vida humana como sendo aquela que é vulnerável à fortuna, à catástrofe, implicando com isso concepções carregadas de sentido sobre o papel das peças trágicas no aprendizado moral humano que realçam não apenas a importância de se levar em conta o problema do conflito de valores, mas também que chamam a nossa atenção para o fato de que mesmo diante de tanta fragilidade muitas perversidades poderiam ser evitáveis. E não apenas nelas, mas em nossas vidas no presente, os exemplos são diários.
} 
muitas vezes de maneira velada e sob a base de discursos e práticas supostamente democráticas, mas arbitrários, autoritários, violentos, burocráticos, corruptos, desumanos. São exemplares, nesse caso, as interferências do sistema econômico na esfera da atuação política que se opõem drasticamente e representam uma ameaça à existência social, plural e democrática em nossos tempos.

A ditadura militar no Brasil, numa negação do reconhecimento da importância do outro na construção de experiências e vivências comuns, mostrou um abismo, uma enorme incompatibilidade entre o poder e a violência, entre a vida pública, política e o interesse pessoal ou de pequenos grupos, violentos inclusive, entre a autoridade a ser exercida num viver compartilhado, comum e o autoritarismo que se regula pelo uso da força, da arbitrariedade, do desrespeito, da intolerância e da discriminação em face da esmagadora maioria, entre o respeito a valores pautados nos direitos humanos e na democracia e o manifesto desrespeito à importância de tais valores num modo de viver comum.

As prisões arbitrárias eram realizadas no Brasil da ditadura militar, cotidianamente, sem qualquer amparo legal e jurídico. Prendia-se quem o governo e os seus departamentos e centros de operações, tais como o DOPS (Departamento de Ordem Política e Social) e o DOI-CODI (Destacamento de Operações de Informações - Centro de Operações de Defesa Interna), julgassem ameaçadores à ordem estabelecida. Do mesmo modo, torturas, mortes e desaparições de pessoas eram rotineiras no contexto de nossa sociedade, materializando o esvaziamento de leis, direitos e liberdades em prol da violação e do desrespeito. Dito de outro modo, um deserto à moda brasileira.

Isso reforça o sentido do pensamento de Hannah Arendt sobre a expansão de um mundo deserto na modernidade e sua crise refletida na esfera da vida comum, pública, política e também educacional no limiar do século XX, uma crise que pode ser percebida na educação. Arendt chama a nossa atenção para o fato de que temos uma crise no mundo moderno que se reflete no âmbito da educação.

Como atribuir sentido às nossas instituições, leis, direitos, liberdades, valores, autoridade e responsabilidade pelo que nos é comum, diante de tantos desrespeitos, usurpações, violações, arbitrariedades e autoritarismos como os predominantes no decorrer do século XX? Por outro lado, como compreender o sentido do educar em um mundo deserto? Como compreender o sentido de autoridade e de responsabilidade que o educador assume no processo de desertificação de coisas e de pessoas? 
O educador é aquele que apresenta um sentido de pertencimento e de amor mundi que o faz assumir a tarefa ${ }^{12}$ de formação para a vida pública aos novos, como algo que deve ser cuidado, compartilhado, preservado, renovado ou até mesmo inventado. E qual é o sentido de um modo de viver comum? Noutros termos, qual é o sentido e o que pode representar a vida democrática e o viver num mundo comum em nossos dias? Diante de tudo que já foi visto, vivido e sofrido pelas pessoas no Brasil e no mundo, ainda faz algum sentido pensarmos numa formação humana e num viver comum em nossa sociedade que respeite direitos, liberdades, valores, pessoas?

Entendemos que sim, principalmente por tudo que vimos, vivemos e sofremos por aqui. É um juízo, uma escolha por trilhar um caminho diferente, produzido pela formação humana, almejando encontrar alguma coisa ou alguém com quem possa compartilhar um mundo comum de significações e realizações por julgar isso importante e bom. Esse parece ser o problema a ser enfrentado. E a figura do educador tem possibilidade de contribuir significativamente nessa busca incessante por trilhar caminhos que nos levem a valorizar a importância do que nos é comum. Caso contrário, só nos restaria nos adaptarmos às condições do mundo moderno, habituarmo-nos a viver sozinhos e introspectivamente ${ }^{13}$ num mundo desértico em que predomina o nada e o ninguém, onde não há o que fazer, lugar da não esperança. Dito de outro modo, um mundo em que falta coragem para seguir caminhando com vistas a encontrar alguma coisa e, especialmente, alguém com quem dialogar, agir, realizar algo em comum, compartilhar um mundo de significações e realizações ou mesmo ser tocado por algo que nos leve a pensar ${ }^{14}$.

Em consonância com o pensamento de Arendt, que recorre à experiência do mundo antigo para nos oferecer não um modelo a ser seguido, mas um exemplo a ser pensado em

\footnotetext{
12 Tarefa esta que parece ter sentido na medida em que pode ser concebida como formação para a vida pública, o viver comum, e que por isso deseja formar os novos para esse viver comum, essa vida boa, essa experiência comum plena - que em nada se assemelha a qualquer tipo de experiência autoritária, totalitária. Voltaremos mais adiante a esse assunto após tratarmos da noção de mundo comum quando adentrarmos a questão da nossa moderna perda da autoridade.

${ }_{13}$ Veremos mais adiante em que medida a introspecção pode contribuir para que não enxerguemos a possibilidade de vivenciarmos uma experiência comum na medida em que nosso referencial se restringe a um eu introspectivo (que não dialoga com o outro) e não a um nós compartilhado, mesmo que seja como diálogo entre o eu e o outro eu mesmo que realizamos quando estamos pensando, como observa Arendt, inspirada na figura de Sócrates, em diversos momentos, tais como aparece em A Promessa da Política.

${ }^{14}$ Diálogo entre o eu e o outro eu-mesmo, como ressalta Arendt, inspirada nos ensinamentos dos antigos, especialmente Sócrates, dentre outras, em diversos momentos da obra A promessa da política. Os estudos que Arendt realiza a partir do caso Eichmann em Jerusalém são bastante significativos do que pode representar o pensar ou, ao invés disso, a sua ausência. E isso aparecerá em diversos momentos da obra da autora, tais como inclusive em sua obra Responsabilidade e Julgamento.
} 
nosso presente, julgamos que não é bom para o homem estar sozinho no mundo ${ }^{15}$. Daí ser crucial refletirmos sobre a importância de estarmos acompanhados por alguém no mundo e de como escolhermos estar especialmente em boas companhias entre homens, coisas e pensamentos em nossas trajetórias humanas ${ }^{16}$. Esta é uma ideia central, que precisa ser desenvolvida. Ela pode ser a trilha para levar ao papel da educação nesse tipo de formação. E o papel da formação humana parece ser decisivo nesse sentido: formar para a vida comum.

A educação e a figura do educador assumem papéis fundamentais na medida em que têm possibilidades de dizer o que o mundo é, de resistir às modernas condições de uma vivência desértica e, como veremos, buscarmos a experiência de uma vida boa plena, como diriam os antigos gregos, mais igual, livre, justa, pública e política. E a educação em direitos humanos como formação para a vida pública e política pode contribuir muito neste sentido. É fundamental que reflitamos sobre o significado de tais questões que, em última instância, pode nos levar, inclusive, a uma tomada de decisão sobre o modo de se viver uma existência social num ambiente que transcende a vida de cada um, que respeita a pluralidade humana.

É por isso que temos nos valido permanentemente da importância de ressaltar o valor da pluralidade humana e do diálogo entre as pessoas nessa nossa caminhada humana, um diálogo também com autores que refletiram que deram importância ao pensar de tais indagações, e que julgamos terem nos apresentado caminhos interessantes, verdadeiras pérolas para a compreensão de nossa própria história e para nossa formação humana com vistas à valorização de nossas experiências nos ambientes que nos são comuns. Dentre os autores, é com Hannah Arendt que estabelecemos um diálogo especial, fundamentalmente no trato com a educação, com a política e com a noção de mundo comum, por seu olhar sobre a educação como sendo importante na formação dos novos para a vida pública e política.

\footnotetext{
${ }^{15}$ Além da experiência do mundo antigo, Arendt recorre também a algumas revoluções como exemplos.

${ }^{16} \mathrm{E}$ como isso é humanamente bom. Humanista, que se recusa a ser coagida, como resultado "de uma atitude que sabe como preservar, admirar e cuidar das coisas do mundo". Cultura animi, recordando com Arendt daquilo que "os romanos - o primeiro povo a encarar seriamente a cultura, à nossa maneira - pensavam dever ser uma pessoa culta:_alguém que soubesse como escolher sua companhia entre homens, entre coisas e entre pensamentos, tanto no presente como no passado" (ARENDT, 1990: 281). Neste sentido, a educação em direitos humanos como formação para a vida pública e política apresenta-se aqui como um convite, uma escolha por tais valores e companhia no mundo comum.
} 
Com o propósito de avançar nessa busca que não cessa, pretendemos então refletir especialmente sobre a seguinte questão: o que é o mundo comum no pensamento de Hannah Arendt e por que tal noção tanto nos interessa em nosso presente e deve ser pensada em nossa sociedade (com vistas à ampliação da democracia em nossas instituições, por exemplo)? Esta noção arendtiana de mundo comum nos ajuda a pensar a nossa realidade pública e política no presente, bem como no trato com questões que envolvam a formação de uma cultura valorativa de direitos humanos e de democracia participativa, como forma de existência social que afirme direitos e liberdades e que pode ser capaz de oferecer as condições para a criação de novos direitos justamente por conter esse caráter público, político, conflituoso, repleto de ambiguidades?

Mais uma vez entendemos que sim. Vejamos o porquê, partindo desta noção de mundo comum no pensamento arendtiano que parece escolher um caminho de certa forma distinto, corajoso, questionador, que contem certa dose dos elementos e aspectos trágicos do mundo grego antigo, bem como da experiência da fundação romana e que parece ir à contramão dos tempos modernos e do que nos fora oferecido por ele, especialmente em seu aspecto mais pessimista, introspectivo, cético, solitário, niilista, desértico, destrutivo, violento e descrente em relação ao mundo comum e às pessoas que nele convivem, na medida em que almeja realçar em nossos tempos de crise no mundo (perda da autoridade, por exemplo), justamente, que continuemos a dialogar uns com os outros num mundo que é conflito, ambiguidade, vulnerabilidade, fragilidade.

Lembremos que Arendt está inserida no contexto histórico do século XX assolado por duas grandes guerras mundiais e pelos horrores das experiências totalitárias na Europa, tais como o nazismo na Alemanha e a perseguição a judeus como Arendt que, segundo sua biografia denominada Por Amor ao Mundo, chegou mesmo a ser presa e precisou fugir do país. Resistente a um único rumo que se adapte às condições de um mundo deserto onde predomina o nada e o ninguém, Arendt instiga-nos a pensar a possibilidade de realizar algum tipo de trajetória mais humana e comum, dialética e dialógica neste sentido.

Recorrendo ao exemplo dos gregos antigos, Arendt sugere-nos um caminhar que manifeste não apenas um resistir às condições desérticas de um mundo moderno em crise, mas também um querer, pensar e, especialmente, julgar importante que busquemos encontrar alguém com quem possamos estabelecer diálogos, ações compartilhadas, convivência num ambiente fecundo ao que nos é comum.

Por esse aspecto, um caminhar que resiste à ideia, característica dos tempos modernos, de se habituar e seguir rumando numa única direção por um ambiente desértico, 
onde não temos a possibilidade de encontrar alguma coisa e alguém e vivemos uma vida solitária, introspectiva, cética, descrente no mundo e nas pessoas. Ao contrário disso, acredita e tem esperanças de que temos a possibilidade (como um milagre) de encontrarmos alguma coisa e, especialmente, outro alguém com quem possamos compartilhar uma vida comum plena (não desértica), pois que julga não ser bom para o homem estar sozinho.

Uma pessoa, diferentemente de um mero vivente, deve estar em companhia de outros com quem possa dialogar e agir em conjunto, alguém que aparece no ambiente comum - palco das aparições - através da ação e do discurso realizando feitos, ditos, eventos que nos são extremamente importantes em nossas vivências e experiências comuns. E mesmo quando em pensamento (logos), reflexão, num dialogo entre o eu e o outro eu-mesmo, como dizia Arendt inspirada nos ensinamentos dos antigos, especialmente Sócrates, sobre o sentido do pensar e mesmo da possibilidade do viver comum. Isso aparece em muitos momentos no pensamento de Arendt, tais como na sua obra A Promessa da Política, em seu texto intitulado Sócrates que traduz de certa forma o sentido de uma experiência comum que realça a importância dentre outras coisas da pluralidade humana e do diálogo para o viver comum.

Reafirmamos que esse caminhar, paradoxalmente esperançoso e trágico, leva-nos a viver, agir em conjunto, debater, compartilhar um mundo comum de significações e realizações, de sentimentos, emoções, afeições e pertencimento num mundo, no qual a formação humana tem um papel fundamental na medida em que se realçam conflitos, fragilidades, bondades. Afinal, o mundo comum é a nossa casa e por isso precisa ser cuidado - um cuidado que envolve preservação, manutenção, mas que também pode envolver renovação, transformação, invenção - para vivermos uma melhor vida humana, uma vida boa e uma caminhada mais humana e feliz. ${ }^{17}$

Numa acepção mais próxima ao exemplo e ao sentido da experiência política do mundo antigo das tragédias gregas e do pensamento de Aristóteles, instiga-nos levar em consideração, como observa Nussbaum (2009), a importância de se pensar sobre a questão da presença da fortuna em nossas vidas, da vulnerabilidade humana e, neste sentido, da

\footnotetext{
17 "Sob qual céu" queremos viver, em face da fortuna, como chama a nossa atenção Martha C. Nussbaum, em A Fragilidade da bondade: fortuna e ética na tragédia e na filosofia grega, em outras palavras, "onde queremos viver" e "quem pensamos ser"? Como observa mais adiante, algo que diz respeito ou que se relaciona com a excelência humana (areté), de caráter, do intelecto e a felicidade (eudaimonía), no sentido de "algo como "viver uma vida boa para um ser humano"; ou, como sugeriu um escritor recente, John Cooper, "florescimento humano". Aristóteles nos diz que é equivalente, no discurso ordinário, a "viver bem e fazer bem"." - página 05 .
} 
fragilidade da bondade (enquanto algo que se relaciona à eudaimonía). Como veremos mais adiante, essa vida boa do mundo grego antigo assim o pode ser levada em conta justamente porque, respeitando a vulnerabilidade, a roda da fortuna que caminha lado a lado conosco, tem a possibilidade de ser uma vida mais igual, livre, justa e feliz: boa em toda a sua fragilidade, vulnerabilidade, fortuna.

Lembrando Guimarães Rosa (1988), em seu conto A terceira margem do rio que aparece em seu livro Primeiras Estórias: nem cá, nem lá, travessia - "rio abaixo, rio a fora, rio a dentro - o rio" ${ }^{18}$. Como uma espécie de escolha por uma travessia - entre o nascer e o morrer - que considera importante compreender e ver o mundo do ponto de vista do outro numa perspectiva de realização de uma caminhada plural, comum, dialética, dialógica $^{19}$, discursiva, reflexiva, que assim o é justamente por acreditar na possibilidade de que possamos encontrar outro alguém (para além do nosso curto caminhar enquanto uma vida biológica) com quem possamos compartilhar um mundo comum de significações, valores, realizações, obras, feitos, ditos (artificialismos humanos), nos quais possamos nos reconhecer uns aos outros como alguém, singularmente, e sentirmos um pertencimento comum que nos leva a querermos permanecer participando em nossos dias de uma longa caminhada que não é só nossa, mas de todos, é que julgamos por bem estar em companhia não do modelo, mas do exemplo da experiência grega da polis.

Seguindo os conselhos de Arendt, um exemplo que nos apresenta o sentido de mundo comum, como veremos a seguir, pautado na experiência política que é atrelada à ideia de igualdade, liberdade, publicidade, justiça, imortalidade e mesmo bondade e felicidade (viver bem), inspira-nos a pensar o seu sentido em nossos tempos como algo que possa contribuir na busca por uma experiência e vivência numa sociedade mais justa, igual, livre, comum: um caminho talvez mais belo e feliz porque humano e compartilhado - que

${ }^{18}$ Guimarães Rosa.Trecho extraído do conto A terceira margem do rio, do livro Primeiras Estórias, Editora Nova Fronteira, Rio de Janeiro, 1988, p. 32.

${ }^{19}$ A terceira margem do rio, espaço fronteiriço, dialógico, discursivo, reflexivo, lugar terceiro: "e o rio-riorio, o rio - pondo perpétuo." Veja o que dizia: “A gente teve de se acostumar com aquilo. Às penas que, com aquilo, a gente mesmo nunca se acostumou, em si, na verdade. Tiro por mim, que, no que queria, e no que não queria, só com nosso pai me achava: assunto que jogava para trás meus pensamentos. O severo que era, de não se entender, de maneira nenhuma, como ele aguentava. De dia e de noite, com sol ou aguaceiros, calor, sereno, e nas friagens terríveis de meio-do-ano, sem arrumo, só com o chapéu velho na cabeça, por todas as semanas, e meses, e os anos - sem fazer conta do se-ir do viver. Não pojava em nenhuma das duas beiras, nem nas ilhas e croas do rio, não pisou mais em chão nem capim." E mais adiante: "Eu permaneci, com as bagagens da vida. Nosso pai carecia de mim, eu sei - na vagação, no rio no ermo - sem dar razão de seu feito." Guimarães Rosa.Trecho extraído do conto A terceira margem do rio, do livro Primeiras Estórias, Editora Nova Fronteira, Rio de Janeiro, 1988, p. 32. Espaço repleto de contradições, conflitos, questionamentos sobre si e sobre o mundo, em que se misturam em todos os níveis, como observa Antônio Candido, "o real e o irreal, o aparente e o oculto, o dado e o suposto". CANDIDO, Antonio. O homem dos avessos. In: COUTINHO, E. P. (Org.). Guimarães Rosa. Rio de Janeiro: Civilização Brasileira/Brasília: INL, 1983. (Coleção Fortuna Crítica) - página. 304. 
de certa forma traduza esse lugar onde queremos viver. E para que esse nosso caminhar comum tenha possibilidades de ser realizado, a formação, a educação em direitos humanos, inclusive, tem um papel fundamental na medida em que assume a responsabilidade por esse mundo compartilhado, dizendo o que ele é, como observa Lefort, conflito num feitio não totalitário (2011). Ou seja, um caminhar que reflete uma espécie de escolha, intenção, cultivo, valorização: formar para ser livre, igual, feliz numa vida boa plena.

Caminhemos com Arendt. É com base na experiência da polis grega e da república romana que a autora delineia a sua noção de mundo comum que ainda tanto nos serve para pensarmos as nossas próprias questões e experiências no presente. Inspirada nos ensinamentos dos antigos e crítica das transformações ocorridas na modernidade, especialmente a partir das catástrofes monstruosas ocorridas no século XX, Hannah Arendt reflete sobre o sentido que a política ainda poderia ter, após a eclosão de duas grandes guerras mundiais e a ascensão do totalitarismo nazista na Alemanha, atribuindo para tanto uma importância significativa à noção de mundo comum que tem suas raízes no pensamento do mundo antigo.

Caminhamos também com os gregos antigos, poetas trágicos, pré-socráticos, Sócrates, Platão e Aristóteles, dentre outros. Essa reflexão nos é bastante interessante na sociedade brasileira atual, na medida em que optamos, nas últimas décadas, por uma sociedade de cunho democrático e não ditatorial, ou seja, ratificamos a ideia de que a política ainda pode ter algum sentido em nossas vidas no presente, caso contrário, vivermos ou não a experiência democrática nos é irrelevante, uma sensação que o tempo todo nos persegue ao vivenciarmos experiências autoritárias e totalitárias em nosso presente que se diz fundado sob os pilares da democracia e que nos faz pensar o que é a política, democracia e se temos vivido em nossos dias experiências democráticas autênticas.

$\mathrm{Na}$ apresentação da obra $A$ condição humana, Adriano Correia observa que Hannah Arendt recorre à experiência do mundo antigo para pensar o sentido de mundo comum porque

Hannah Arendt estava convencida de que a oposição entre liberdade e vida biológica está na base de tudo o que podemos compreender como política e das virtudes especificamente políticas. Para ela, poderíamos inclusive dizer que é o próprio fato "de que hoje o que está em jogo na política é a existência nua e crua de todos o sinal mais evidente da calamidade em que nosso mundo caiu". Isso decorre, para Arendt, da 
moderna desconsideração da necessária distinção entre vida biológica e política, assim como entre a felicidade que se experimenta na satisfação das necessidades vitais e a que se experimenta na fruição da liberdade política (NUSSBAUM, 2009: 301).

Correia ressalta ainda que "a despeito de seu diagnóstico da irremediável ruptura do fio da tradição, em nossos tempos, Hannah Arendt se liga à tradição do nosso pensamento político quando concebe como desejável a conservação da "consagrada linha divisória e protetora entre a natureza e o mundo humano" "(NUSSBAUM, 2009: 301), realçando que é dessa diluição da fronteira entre a natureza e o mundo humano que provêm as implicações mais relevantes de tais transformações na modernidade.

Ao refletir sobre o sentido do mundo comum e da política, aprofundando seus estudos sobre tal temática, Arendt vai ao que crê ser às origens do pensamento político ocidental que parecem ter sido dadas no mundo antigo, especialmente na polis ${ }^{20}$ grega, buscando repensar esse evento, essa original invenção e compreensão grega da política e do mundo comum. E percebemos que para Arendt é perfeitamente cabido empregar o termo político no sentido da polis, na medida em que o termo é empregado, em todas as línguas europeias, com base na antiga organização da cidade-estado grega, que segundo ela, "evoca as experiências da comunidade que pela primeira vez descobriu a essência e a esfera do político" (ARENDT, 1990: 201). E como podemos delinear tal experiência? Quais são as suas principais características?

Realizando um estudo sobre os principais traços da experiência do mundo antigo sobre tal temática, podemos observar que o advento da polis (cidade-estado) situado entre os séculos VIII e VII a.C. na Grécia Antiga constitui um acontecimento decisivo na história do pensamento grego, marcadamente um começo e uma verdadeira invenção ${ }^{21}$. As relações entre os homens e a vida social tomam uma forma nova, cuja originalidade, será plenamente sentida pelos gregos. Na polis estabelecesse um vínculo recíproco, um estreitamento das relações entre a política e o $\log _{0}{ }^{22}$ (discurso, pensamento). A arte da

\footnotetext{
${ }^{20}$ Segundo Glossário de termos gregos, a polis significa cidade, cidade-estado; reunião dos cidadãos em seu território e sob suas leis. Dela deriva a palavra política, politikós: o cidadão, o que concerne ao cidadão, os negócios públicos, a administração pública, a vida pública (CHAUí, 1994).

${ }^{21}$ Nossos estudos são pautados em diversos autores que estudaram o mundo antigo, tais como Jean-Pierre Vernant, Moses Finley, Werner Jaeger e a própria Arendt, dentre outros.

${ }^{22} \mathrm{O}$ termo logos sintetiza vários significados que, em português, estão separados, mas unidos em grego. Vem do verbo légo (no infinitivo: légein) que significa: 1) reunir, colher, contar, enumerar, calcular; 2) narrar, pronunciar, proferir, falar, dizer, declarar, anunciar, nomear claramente, discutir; 3) pensar, refletir, ordenar; 4) querer dizer, significar, falar como orador, contar, escolher; 5) ler em voz alta, recitar, fazer dizer. Lógos é:
} 
política constitui-se essencialmente como exercício da linguagem e o logos originariamente, através de sua função política, toma consciência de si mesmo, de suas regras, de seus argumentos e de sua eficácia no mundo. Esta unidade de sentidos do termo grego logos leva os historiadores da filosofia, segundo os ensinamentos de Marilena Chauí, que aparecem em sua obra Introdução à História da Filosofia, dos pré-socráticos a Aristóteles, "a considerarem que, na filosofia grega, dizer, pensar e ser são a mesma coisa" (CHAUÍ, 1994: 353), daí ser crucial o diálogo, o conflito, no sentido de um debate contraditório entre logos na esfera comum, pública e política.

Na obra As origens do pensamento grego, Jean-Pierre Vernant chama a nossa atenção para algo que nos interessa sobremaneira, a primeira característica que se destaca nessa forma nova que surge, entre os gregos, denominada polis, é o predomínio da palavra sobre os demais instrumentos do poder. Na polis a palavra torna-se "o instrumento político por excelência, a chave de toda autoridade no Estado, o meio de comando e de domínio sobre outrem" (VERNANT, 1972: 34). A palavra consiste na amplitude do debate contraditório que supõe haver um público ao qual ela se dirige, através do discurso, da argumentação, como que a um juiz que decide em última instância, através de uma escolha puramente humana, a vitória daquele que apresenta a maior força de persuasão discursiva, todas as questões de interesse público são submetidas à arte oratória, devendo resolver-se na conclusão de um debate contraditório que ocorre a plena luz do dia e sob o olhar de todos.

Por esse aspecto destaca-se a segunda característica da polis que é justamente a publicidade em proveito do grupo e sob o olhar de todos. Um domínio público no duplo sentido do termo, isto é, primeiramente, um setor de interesse comum que se opõe aos assuntos de interesse privado e, em segundo lugar, práticas abertas realizadas em plena luz do dia que se opõe a processos secretos. Essas características da polis grega nos servem de exemplo e são bastante oportunas para pensarmos o exercício da democracia e o sentido da

palavra, o que se diz, sentença, máxima, exemplo, conversa, assunto da discussão; pensar, inteligência, razão, faculdade de raciocinar; fundamento, causa, princípio, motivo, razão de alguma coisa; argumento, exercício da razão, juízo ou julgamento, bom-senso, explicação, narrativa, estudos; valor atribuído a alguma coisa, razão íntima de uma justificação, analogia. Lógos reúne numa só palavra quatro sentidos: linguagem, pensamento ou razão, norma, ou regra, ser ou realidade íntima de alguma coisa. No plural, lógoi, significa: os argumentos, os discursos, os pensamentos, as significações. -logia, que é usado como segundo elemento de vários compostos, indicando: conhecimento de, explicação racional de, estudo de. Diálogo, dialética, lógica são palavras da mesma família de logos. O logos dá a razão, o sentido, o valor, a causa, o fundamento de alguma coisa (CHAUÍ, 1994). 
política em nossos dias. Como andam, por exemplo, tais características em nossa sociedade?

Segundo Vernant, esse duplo movimento de democratização e de divulgação terá consequências decisivas para a cultura e para a formação do pensamento político grego, comportando uma profunda transformação ocasionada pelo aparecimento da polis, tornando-se elementos de uma Paideía ${ }^{23}$, de uma cultura comum, conhecimentos, valores, técnicas, julgamentos são levados ao espaço público, à praça pública, e submetidos à crítica e à controvérsia. $\mathrm{O}$ diálogo, o debate contraditório, a polêmica passam a valer como as regras do jogo intelectual e político, tornando-se elementos fundamentais na formação do homem grego (JAEGER, 1995). A lei da polis não é mais imposta pela força do prestígio religioso ou pessoal, mas sim por processos de ordem dialética, pública e discursiva. Como observa Chaú, "da assembleia dos guerreiros e da palavra-diálogo, pública e igualitária, nasce a polis e é inventada a política." ${ }^{24}$.

Na polis a palavra passa a formar o instrumento da vida política e a escrita fornece, no plano intelectual, o meio de uma cultura comum permitindo a divulgação de conhecimentos outrora reservados ou interditos, podendo satisfazer a função de publicidade na cidade-estado, pois ela própria, a escrita, torna-se o bem comum de todos os cidadãos, muito próxima da língua falada em termos de direito ${ }^{25}$. Nesse ambiente fecundo à política, a dike $e^{26}$ (justiça) pela publicidade que lhe é conferida pela escrita, terá a

\footnotetext{
${ }^{23}$ Paideía, termo grego que significa educação ou cultivo das crianças, instrução, cultura. O verbo paideúo significa: educar uma criança (paîs-paidós em grego), instruir, formar, dar formação, dar educação, ensinar os valores, os ofícios, as técnicas, transmitir ideias e valores para formar o espírito e o caráter, formar para um gênero de vida. Da mesma família é a palavra Paidéia, ação de educar, educação, cultura (CHAUÍ, 1994).

${ }^{24}$ Segundo Chaú, "A palavra dos guerreiros é completamente diferente da palavra inspirada, mágica e eficaz. Em primeiro lugar, porque não é uma palavra solitária e unilateral, proferida por um Senhor da Verdade, mas é uma palavra compartilhada: é a palavra-diálogo. Em segundo lugar, porque não é uma palavra de um grupo secreto de iniciados, mas uma palavra pública dita em público. Em terceiro lugar, porque não é uma palavra religiosa, mas leiga e humana. Antes do combate, os guerreiros se reúnem num círculo, formam uma assembleia e cada um, indo ao centro, tem o direito de falar e de ser ouvido, propondo táticas e estratégias para o combate. Após a batalha, novamente os guerreiros se reúnem em círculo, formam uma assembleia e discutem a repartição dos espólios, cada qual indo ao centro para exercer seu direito de falar e de escolher sua parte. Perante a assembleia, todo guerreiro pratica dois direitos: o da isegoría (o direito de falar e emitir opinião) e o da isonomía (todos os guerreiros são iguais perante a lei de seu grupo, lei feita pelo próprio grupo)" (CHAUÍ, 1994: 36).

${ }^{25}$ Uma técnica de amplo uso, livremente difundida no público, tornada bem comum e não mais restrita ao saber especializado dos escribas, "ao lado da recitação decorada de textos de Homero ou de Hesíodo - que continua sendo tradicional - a escrita constituirá o elemento de base da paideia grega" (VERNANT, 1972: 36).

${ }^{26}$ Dike, que dizer, entre os gregos, Justiça (personificada na deusa Díke, a Justiça, a Vingança, o Castigo). Inicialmente, díke significa: uso, maneira ou modo de ser e de agir, à maneira de, ao modo de, costume. A seguir, o uso e o modo de ser ou agir se torna uma regra de conduta, a norma correta de ser e agir, ganhando assim, o sentido jurídico de certo, justo, conforme as leis e ao direito; donde: justiça. Por extensão, refere-se
} 
possibilidade de encarnar-se num plano propriamente humano, sem deixar de aparecer como um valor ideal, realizando-se na lei, regra comum a todos, superior a todos, norma racional, submetida à discussão, ao debate contraditório e passível de modificação por decreto, mas que não deixa de exprimir uma ordem concebida ainda como sagrada. A dike realiza-se nas leis e os saberes agora divulgados na polis tornam-se públicos por meio da escrita, bem comum da cidade que, como lei, impõe-se a todos. A verdade do sábio entregue à escrita e tornada pública é exposta aos olhares da cidade-estado, devendo ser por direito acessível e submetida ao julgamento de todos, como o debate políticocontraditório, na esperança de que possa ser aceita e reconhecida por todos ${ }^{27}$.

Substituindo outras provas oriundas das revelações interditas e caminhando lado a lado com o logos, as técnicas de discussão, argumentação e reflexão, a Sophía ${ }^{28}$ (Sabedoria) e a Philo Sophía ${ }^{29}$ irão apontar novos percursos de ascese à "verdade", novas regras de vida e vias de pesquisas marcadamente influenciadas pelo debate público ${ }^{30}$. Essa

ao processo judiciário ou ao julgamento de uma ação para saber se está ou não conforme a justiça, à lei, ao direito. No plural, significa a consequência de um julgamento: decreto, punição, recompensa. A função da díke é impor uma regra de equilíbrio entre os seres e punir a transgressão da regra. Estabelece uma medida justa para avaliar o modo de ser e de agir dos homens e, a seguir, por extensão, é vista como impondo medida a todas as coisas do mundo (natural e humano) (CHAUÍ, 1994).

${ }^{27}$ No universo da polis os antigos sacerdócios ligados ao poder divino e outrora pertencente a alguns (gene) serão confiscados em proveito de todos, transformando-se em cultos oficiais da cidade. As narrativas secretas e as fórmulas ocultas, agora sob o olhar de todos, são despojados dos seus mistérios e poderes religiosos para tornarem-se "verdades" que os Sábios irão debater no espaço público: apresentando-se como um traço forte e bastante característico do universo da política em sua acepção original. Entretanto, nessa democratização do privilégio religioso, o mistério não se coloca numa perspectiva de publicidade, pois o que define o mistério como mistério é, justamente, a pretensão de atingir uma verdade inacessível por vias normais, que não pode de forma alguma ser exposta, pois "quaisquer que sejam a lucidez dos chefes políticos e a sabedoria dos cidadãos, as decisões da assembleia têm por objeto um futuro que permanece fundamentalmente opaco e que não pode ser alcançado completamente pela inteligência. É então essencial assegurar-se o seu controle, na medida do possível, por outras diligências, que empregam não mais meios humanos, mas a eficácia do rito. $\mathrm{O}$ "racionalismo" político que preside às instituições da cidade se opõe certamente aos antigos processos religiosos do governo, mas sem por isso excluí-los de maneira radical” (VERNANT, 1972: 39).

${ }^{28}$ Sophía: Sabedoria. Inicialmente significa habilidade manual para as artes e técnicas. A seguir, a sabedoria moral ou prudência do homem razoável e sensato. Finalmente, passa a significar o conhecimento teórico em seu ponto de mais alta perfeição. O verbo sophízo significa: tornar hábil, prudente, sábio. Como outrora as revelações dos mistérios pretendiam, os ensinamentos da Sabedoria pretendem transformar o homem no íntimo, elevando-o a uma condição superior, fazendo dele um ser único, um theios anér (quase um deus). Neste sentido a polis dirige-se ao Sábio, pedindo-lhe a solução de seus males, precisamente por lhe aparecer como um ser excepcional (um homem-divino) que, através da palavra ou da escrita, e do debate contraditório transmite uma verdade, paradoxalmente, pertencente a um mundo estranho à vida ordinária, mas que agora é discutido em plena praça pública à luz do dia. A primeira sabedoria, de natureza paradoxal, constitui-se numa espécie de contradição em que o mistério é levado à praça pública, fazendo dele o objeto de um estudo, no qual a invenção da política aparecerá como seu contrário (CHAUÍ, 1994).

${ }^{29}$ Philo Sophía: Amigo da Sabedoria. Compostas formam Filosofia. Amizade à sabedoria, amor pelo saber, procura ou busca do saber (CHAUÍ, 1994).

${ }^{30}$ Como observa Martha C. Nussbaum (2009), as tragédias gregas têm papel fundamental, realçando diversas ambiguidades desse ambiente extremamente fecundo à política e ao debate contraditório, bem como, inclusive e especialmente, à vulnerabilidade de tudo isso (fortuna). 
ambiguidade marca o advento da polis, a origem da filosofia grega e o contexto histórico no qual a atividade política surgirá, caracterizando-se pela publicidade do debate contraditório no espaço público, um discurso público, dialogal, compartilhado, decisional. Tal debate se estabelece na troca de opiniões, bem como na competência discursiva para elaborar e desenvolver argumentos que persuadam e torne válida e correta a opinião emitida, ou mesmo rejeitada se frágil na argumentação, no qual o logos volta-se para os interesses determinados pela vida comum (CHAUÍ, 1994).

Desta forma, o universo espiritual da polis será caracterizado pelo prestígio da palavra, da escrita, e pelo desenvolvimento de práticas públicas. Outro aspecto importante que irá aparecer no interior da polis nascente será o conceito de isonomía $^{31}$ (isonomia) definido em poucas palavras pela igualdade de participação de todos os cidadãos no exercício do poder no regime democrático. Aqueles que compõem a polis, por mais que sejam diferentes em suas origens ou funções, aparecem de certa maneira semelhantes uns $\operatorname{aos}_{\text {outros }}{ }^{32}$. A partir de tais traços que aparecem fortemente arraigados como elementos de uma cultura comum, esse universo espiritual da polis, já no século VI a.C., será caracterizado, dentre outras coisas, fundamentalmente, pelo prestígio da palavra e da escrita, pelo desenvolvimento das práticas públicas (a publicidade) e pelo traço da isonomia no plano político, no sentido de uma participação igualitária de todos os cidadãos da cidade no exercício do poder. É nesse ambiente, conforme observa Moses Finley (1997), que se tem a invenção da política.

Segundo Chauí, dois princípios fundamentais definem a cidadania neste espaço cívico que liga o ideal igualitário à realidade política: a isonomia (a igualdade de todos os cidadãos perante a lei) e a isegoria (o direito de todo cidadão de exprimir em público sua opinião, vê-la discutida e considerada na decisão tomada coletivamente),

\footnotetext{
${ }^{31}$ Isonomía: inicialmente, significa repartição igual; a seguir, significa igualdade de direitos perante a lei no regime democrático (CHAUÍ, 1994).

${ }^{32}$ Neste aspecto, tal semelhança propicia a criação da unidade da polis, "para os gregos, só os semelhantes podem encontrar-se mutuamente unidos pela Philia, associados numa mesma comunidade. O vínculo do homem com o homem vai tomar assim, no esquema da cidade, a forma de uma relação recíproca, reversível, substituindo as relações hierárquicas de submissão e de domínio. Todos os que participam do Estado vão definir-se como Hómoioi, semelhantes, depois, de maneira mais abstrata, como os Isoi, iguais. Apesar de tudo o que os opõe no concreto da vida social, os cidadãos se concebem, no plano político, como unidades permutáveis no interior de um sistema cuja lei é o equilíbrio, cuja norma é a igualdade" (VERNANT, 1972: $42)$.
} 
a democracia ateniense não aceita que, na política, alguns possam mais que outros (exclui, portanto, a oligarquia, isto é, o poder de alguns sobre todos); e não aceita que alguns julguem saber mais do que os outros e por isso ter direito de, sozinhos, exercer o poder. Desse modo, exclui da política a ideia de competência ou de tecnocracia. Na política, todos são iguais, todos têm os mesmos direitos e deveres, todos são competentes (CHAUÍ, 1994: 111).

Tal questão a ser pensada - e que tem suas origens no ambiente fecundo da política no mundo dos gregos antigos, especialmente com a invenção da polis - parece-nos muito atual e deve ser levada em consideração no presente não como um modelo a ser seguido, mas como um exemplo a ser pensado. Em sua obra Paideía, a formação do homem grego, Werner Jaeger (1995) chama a nossa atenção para a importância de que o conhecimento essencial da formação do homem constitui fundamento indispensável para todo o conhecimento ou todo o intento de educação atual. Neste sentido, pensar a educação em nossos dias como formação humana para a vida pública requer que entremos em contato com esse exemplo deixado pelo mundo antigo. Esse novo estilo das relações entre os homens obedece na polis às normas de equilíbrio e de moderação traduzidas nas sentenças: conhece-te a ti mesmo, nada em excesso e a justa medida é o melhor, que expressam valores que de certa forma estavam implícitos nas condutas e na vida social do cidadão grego.

Tal esforço de reflexão situou entre os gregos o problema moral no contexto político da cidade, unindo-o ao desenvolvimento da vida pública, cuja história é marcada por conflito de forças, luta entre grupos, debates público, político e contraditório, cuja força é a persuasão e o poder o logos (pensamento, discurso, argumentação), num âmbito em que os homens podem elaborar a sua ética e definir as condições que permitem a instauração do cosmos humano organizado, a ordem do mundo da cidade, o mundo humano fundado a partir do pensamento político: "agora, as ideias, valores, instituições e comportamentos éticos e políticos tornam-se o centro da preocupação filosófica que faz do homem (cidadão) o seu objeto de interrogação" (CHAUÍ, 1994: 45). O espírito de comunidade predominava neste ambiente fecundo à política, onde o poder dos indivíduos deveria inclinar-se diante da lei do grupo, regra geral e comum a todos ${ }^{33}$. Essa cidade unida será

\footnotetext{
${ }^{33} \mathrm{O}$ que é próprio do mundo grego é a reação que tais mudanças suscitam no grupo humano, a recusa a uma situação sentida e denunciada como perda de identidade, a reforma, a refundição da vida social grega com o propósito de organização de acordo com as aspirações comunitárias e igualitárias. Esse esforço de renovação atua em diversos planos, sendo simultaneamente religioso, social, político, econômico, jurídico, "sempre visa a restringir a dynamis dos gene, quer fixar um limite à sua ambição, à sua iniciativa, ao seu desejo de poder,
} 
concebida como a organização do $\operatorname{kósmos}^{34}$ humano, que na acepção arendtiana nos é apresentada como noção de mundo comum.

Hannah Arendt nos sugere que pensemos sobre o sentido desse nosso mundo comum. E o que é o mundo comum para Arendt? O mundo comum, para ela,

é aquilo que adentramos ao nascer e que deixamos para trás quando morremos. Transcende a duração de nossa vida tanto no passado quanto no futuro, preexistia à nossa chegada e sobreviverá à nossa breve permanência. É isso o que temos em comum não só com aqueles que vivem conosco, mas também com aqueles que aqui estiveram antes e com aqueles que virão depois de nós. Mas esse mundo comum só pode sobreviver ao vir e ir das gerações na medida em que aparece em público. É a publicidade do domínio público que pode absorver e fazer brilhar por séculos tudo o que os homens venham a querer preservar da ruína natural do tempo (ARENDT, 2010: 67).

O mundo comum, segundo a citação, diz respeito a tudo aquilo que é público. E o que designa ser público? Como observa Arendt, o termo público designa aquilo que é perceptível, visível, e aquilo que é comum, dois fenômenos que podem ser correlacionados, mas que não são perfeitamente idênticos, significando, primeiramente, que "tudo o que aparece em público pode ser visto e ouvido por todos e tem a maior divulgação possível. Para nós, a aparência - aquilo que é visto e ouvido pelos outros e por nós mesmos - constitui a realidade" (ARENDT, 2010: 61). Em segundo lugar, significa

o próprio mundo, na medida em que é comum a todos nós e diferente do lugar que privadamente possuímos nele. Esse mundo, contudo, não é idêntico à Terra ou à natureza, enquanto espaço limitado para o movimento dos homens e condição geral da vida orgânica. Antes, tem a ver com o artefato humano, com o que é fabricado pelas mãos humanas,

submetendo-os a uma regra geral cuja coação se aplique igualmente a todos. Essa norma superior é a Dike que o Mago invoca como um poder divino, que o nomóteta promulga em suas leis, e de que pode às vezes inspirar-se o tirano, mesmo se a deturpa, impondo-a pela violência; é ela que deve estabelecer entre os cidadãos um justo equilíbrio a garantir a eunomia: a divisão equitativa dos cargos, das honras, do poder entre os indivíduos e as facções que compõem o corpo social. A Dike assim concilia, harmoniza esses elementos para deles fazer uma só e mesma comunidade, uma cidade unida" (VERNANT, 1972: 52).

${ }^{34}$ Kósmos: termo grego que significa bom ordenamento de coisas e pessoas; boa ordem; arranjo conveniente e adequado; disciplina; organização do cerimonial religioso, organização do Estado; ordem estabelecida; princípio ordenador e regulador das coisas; ordem do mundo e, por extensão, mundo. Inicialmente esta palavra indica a ação dos seres em conformidade com um comportamento estabelecido; a seguir, significa a ação humana organizadora que produz uma ordem nas coisas ou nas instituições; por extensão, refere-se à ordem e organização da natureza ou do mundo (CHAUÍ, 1994). 
assim como com os negócios realizados entre os que habitam o mundo feito pelo homem (ARENDT, 2010: 64).

Com esta definição do termo público, Arendt dá indícios de como concebe o mundo comum e a sua relação com a política, através da ação e do discurso. O mundo comum é artefato humano, feito por mãos humanas e realizado entre os humanos neste domínio público que é o palco das aparências, palco no qual quem é aparece, neste caso, no mundo que aparecemos como "alguém" pelas obras, ditos e feitos realizados. Daí a relevância da singularidade, da pluralidade, da convivência humana, do reconhecimento da importância do outro na construção do mundo comum e da identidade do próprio ser que é alguém nesse mundo reificado e compartilhado entre os que nele convivem e se reconhecem mutuamente.

É nesse espaço público que reconhecemos e somos reconhecidos como alguém. Retomando a citação que inicia este capítulo, Que estica esteira procê passar, é nesse caminho, na travessia por um ambiente que é nosso (espaço-entre), e não apenas meu (isolado, individual, introspectivo), que podemos encontrar companhia no mundo. Para Arendt, o conviver no mundo significa "essencialmente ter um mundo de coisas interposto entre os que o possuem em comum, como uma mesa se interpõe entre os que se assentam ao seu redor; pois, como todo espaço - entre, o mundo ao mesmo tempo separa e relaciona os homens entre si” (ARENDT, 2010: 64, grifos nosso). Como veremos mais adiante - daí a importância de compreendermos a noção de mundo comum no pensamento arendtiano esse mundo comum deve ser apresentado aos novos e tal tarefa deve ser realizada pelo educador, figura que tem a autoridade e a responsabilidade de assim fazê-lo especialmente por amor ao mundo. Hannah Arendt, por exemplo, assim o fez em sua travessia (como tantos outros o fizeram, o fazem e o farão) ${ }^{35}$.

\footnotetext{
${ }^{35}$ Podemos observar isso não apenas nos escritos de Arendt, mas naquilo que nos foi contado sobre sua vida, tal como em sua biografia denominada Por Amor ao Mundo. O aprendizado oriundo das tragédias gregas, bem como a figura de Sócrates também nos é emblemática desta experiência no mundo antigo, servindo-nos de exemplo para pensarmos tais questões no presente. E mesmo em nossos dias, em muitas escolas de educação básica e de ensino superior no Brasil e no mundo, inclusive, embora se insista tanto em afirmar o contrário (meios de comunicação, governos etc.), nas escolas públicas, tais como a que frequento como professor de filosofia do ensino médio na rede pública estadual de São Paulo: EE Dom Pedro I em São Miguel Paulista, periferia de São Paulo, não me canso de vivenciar experiências nas quais me apercebo presenciando professores, educadores, buscando realizar tal tarefa, assumindo com coragem a responsabilidade de assim o fazê-lo mesmo em face de tantos dilemas e adversidades que estão ocorrendo no mundo atual, tais como a corrupção na esfera pública, o predomínio de uma sociedade de consumo, a desvalorização social da educação e da figura do educador (não apenas em termos salariais, mas enquanto
} 
E isso aparece em vários momentos de sua obra. No Prólogo de $A$ condição humana, Hannah Arendt apresenta esse mundo comum como um artifício humano que separa a existência do homem de todo ambiente meramente animal. O mundo comum, como um artifício humano, realizado por esse ser político - isto é, os homens no plural e não o homem no singular - demonstra a relevância do discurso e da ação na feitura do homem e do mundo: a existência de alguma coisa e de alguém que faz, sabe ou experimenta, só pode ter sentido na medida em que pode ser discutido, pois os homens "que vivem, se movem e agem neste mundo, só podem experimentar a significação porque podem falar uns com os outros e se fazer entender aos outros e a si mesmos" (ARENDT, 2010: 05, grifo nosso).

Diferentemente dos bens de consumo e dos objetos de uso, os "produtos" da ação e do discurso, menos duráveis e mais fúteis em relação às outras coisas, são destituídos de tangibilidade e, juntos, constituem a textura das relações e dos negócios humanos que se dão nesse artificialismo do mundo humano. A realidade de tais "produtos" reificados depende inteiramente da pluralidade humana, da presença constante de outros que tenham a possibilidade de, num mundo humano compartilhado, ver e ouvir e, juntos, atestar a sua existência para serem lembrados em sua reificação.

Os "produtos" da ação e do discurso, em sua qualidade mundana, não "produzem", nem geram, em si, coisa alguma. Eles são considerados fúteis tanto quanto a própria vida e dependem, portanto, do mesmo artesanato que constrói as outras coisas do artifício humano para sua realização e manutenção numa vida boa plena e comum. Para que os "produtos" da ação e do discurso se tornem coisas mundanas (feitos, fatos, eventos e organizações de pensamentos ou ideias),

devem primeiro ser vistos, ouvidos e lembrados, e em seguida transformados, 'coisificados', impressos, em pintura ou escultura, em algum tipo de registro, documento ou monumento. Todo o mundo factual dos negócios humanos depende, para sua realidade e existência contínua, em primeiro lugar da presença de outros que tenham visto e ouvido e que lembrarão; e em segundo lugar, da transformação do intangível na tangibilidade das coisas. Sem a lembrança e sem a reificação de que a lembrança necessita para sua realização - e que realmente a tornam, como afirmavam os gregos, a mãe de todas as artes - as atividades vivas da ação, do discurso e do pensamento perderiam sua realidade ao fim de

alguém que representa, ou não, ter algum tipo de autoridade e de responsabilidade por nos dizer o que é o nosso mundo), dentre diversos outros fatores. 
cada processo e desapareceriam como se nunca houvessem existido (ARENDT, 2008: 107).

A realidade e a confiabilidade do mundo humano, como observa Arendt,

repousam basicamente no fato de que estamos rodeados de coisas mais permanentes que a atividade pela qual foram produzidas, e potencialmente ainda mais permanentes que a vida de seus autores. A vida humana, na medida em que é criadora do mundo, está empenhada em constante processo de reificação; e o grau de mundanidade das coisas produzidas, cuja soma total constitui o artifício humano, depende de sua maior ou menor permanência neste mundo (ARENDT, 2008: 107).

E isso tudo nos faz pensar, voltando às questões primeiras, por onde andam nossas esteiras? Coração sambeia? Sob qual céu queremos viver? Alguém para passar? 


\title{
3. POLÍTICA E LIBERDADE NO ÂMBITO DA VIDA PÚBLICA
}

\author{
"Os homens são livres - diferentemente de possuírem o \\ dom da liberdade - enquanto agem, nem antes, nem \\ depois; pois ser livre e agir são uma mesma coisa."
}

Hannah Arendt

Muitos de nós, em algum momento da vida, já nos indagamos sobre quem somos ou mesmo com quem escolhemos seguir no mundo. Questões estas que de alguma forma parecem estar ligadas às nossas escolhas, à nossa condição humana, ao nosso agir no mundo em que vivemos e, por conseguinte, à própria vida política e à formação humana que a precede em nossas vidas. Mesmo em face de tantas dificuldades, ajustar-se a um mundo compartilhado de significações e realizações, especialmente nesse trajeto de escolher quem nos acompanha no mundo, parece ser por alguns aspectos uma questão de escolha, juízo sobre o mundo e sobre nós mesmos.

Com esse propósito, avancemos destacando alguns elementos que julgamos serem cruciais à formação humana para a vida política, relacionados, sobretudo à noção de mundo comum no pensamento arendtiano, dentre os quais a distinção entre os domínios do público e do privado, a pluralidade humana como condição de toda vida política e a liberdade no âmbito da vida pública. Mergulhemos em algumas reflexões sobre o assunto, que obviamente não o esgotam, buscando encontrar possíveis caminhos a serem percorridos no sentido de uma formação humana para a vida pública e política, que reconheça em tais elementos a importância de serem levados em conta e de estar em nossa companhia em nossa caminhada plural e humana.

Teremos como fio condutor de nossas trilhas duas questões: quem somos? Com quem escolhemos seguir no mundo? Indagações que entendemos relacionarem-se intensamente com as esferas da vida pública e da própria formação humana e, especialmente, com a nossa capacidade de realizar pensamentos. Refletir sobre a 
experiência de vida boa dos gregos antigos pode nos servir não como um modelo, mas como um exemplo a ser pensado em nossas trilhas. E, como mencionamos anteriormente, a educação em direitos humanos tem possibilidade de se apresentar como um destes possíveis caminhos no sentido de uma formação humana para a vida pública e política que leva em conta a importância de se dialogar e se refletir sobre tais questões que, como veremos mais adiante, levam-nos a fazer escolhas.

Ao realizar tal empreitada temos percebido o quão valioso nos é resgatarmos o exemplo da experiência de vida boa plena oriunda entre os gregos antigos ${ }^{36}$, especialmente com o advento da polis, e ressaltar características que de alguma maneira permanecem como sendo fundamentais para a ampliação de nossas vivências e experiências comuns no presente, tais como o conflito (debate contraditório), a igualdade (isonomia), a publicidade e a própria vulnerabilidade dessa vida boa à fortuna, características muito importantes à vida política e indispensável à formação humana.

São alguns destes aspectos que buscamos ressaltar obviamente sem pretender esgotar o assunto, muito menos limitar seus possíveis atributos, entre os quais a pluralidade humana, bem como a distinção entre os domínios do público e do privado, da vida política e da vida biológica. Como ressalta Adriano Correia na apresentação da obra $A$ Condição Humana,

\begin{abstract}
Hannah Arendt observa que os antigos tinham por fundamental à política uma clara demarcação entre as demandas naturais da sobrevivência e as demandas políticas da liberdade, que falavam ambas no cidadão. Não obstante, ela sustenta que, desde os gregos, o domínio político se revela como o espaço onde desenvolvemos uma espécie de segunda natureza não ma zoé transfigurada, mas uma nova vida, em acréscimo à vida privada e natural que jamais suprimimos (ARENDT, 2010: XXXVII).
\end{abstract}

Identificar alguns traços da distinção entre os domínios do público e do privado no universo de organização da polis grega, bem como realçar o papel da pluralidade humana como condição de toda vida política, parece-nos algo fundamental para a compreensão do sentido dessa vida boa plena (melhor vida humana) que, em larga medida, representa muito do que buscamos ressaltar no que se refere à esfera da vida pública e política como

${ }^{36}$ A denominada "melhor vida humana", caracterizada por conflito e por vulnerabilidade à fortuna, como vimos com Martha C. Nussbaum (2009), realizando recuos históricos, genealógicos, que contribuam para que tentemos "dar conta" de questões e problemas que fazem parte das nossas experiências no presente. 
exemplo a ser considerado em nosso presente, inclusive enquanto tarefa formativa. Por exemplo, em que medida a ação e o discurso são respeitados e fundamentais na realização da vida política nos dias de hoje? Pensando em termos de democracia no Brasil, há quantas andam a isonomia e a isegoria na vida pública? Ou ainda, podemos de alguma maneira distinguir a vida privada da vida pública no presente? Os nossos noticiários insistem em dizer que não. E nós o que pensamos disso tudo em nosso dia-a-dia?

Aqui recorremos novamente à companhia de Arendt. Esta, por sua vez, recorre aos gregos ao pensar o tema. Por alguns aspectos, e isso nos parece fundamental, a vida pública distingue-se significativamente do âmbito da vida privada e dos interesses próprios, sejam eles de indivíduos ou de pequenos grupos. Atualmente, na esfera social parece não haver qualquer distinção entre os domínios do público e do privado. É concebível pensarmos em nossa sociedade - dita democrática por direito - termos governantes, tais como governadores, prefeitos, senadores, deputados, vereadores, ou mesmo juízes, procuradores e funcionários que ocupam cargos públicos, na condição de subordinados, subalternos àqueles que detêm o poder econômico e que, por isso, ditam as regras do jogo político e da atuação na vida pública? Parece-nos que não.

A distinção entre o público e o privado para os gregos antigos torna-se fundamental na compreensão do próprio sentido da vida pública e política - ou mesmo da sua ausência no mundo - e, ainda, como isso pode ser importante para pensarmos a tarefa da formação humana para a vida comum no presente. Arendt, noutros tempos, não tão distintos dos atuais, aponta para problemas semelhantes aos nossos e recorre ao exemplo dos gregos antigos para nos instigar a refletir sobre o assunto, uma tentativa de compreender seu presente, caso contrário caminhamos inegavelmente para uma vida isolada e introspectiva, sem nada e sem ninguém para compartilhar coisa alguma; um ambiente que se compara a um mundo deserto que nega o mundo comum, no qual se torna extremamente difícil escolher com quem vamos seguir, dialogando, na medida em que não vemos nada nem ninguém para compartilhar significações e realizações no espaço do entre nós.

Em nossos dias, seria possível pensarmos na possibilidade de uma experiência desértica? E, ainda, nomearmos tal crise no ambiente de uma sala de aula e percebermos que professores e alunos não se reconhecem como tais, predominando o nada e o ninguém sobre alguma coisa e alguém? Estaria isso relacionado a uma possível crise no mundo 
comum (espaço do entre nós) refletida na esfera educacional? Entendemos que sim, daí a importância de se pensar no sentido da vida pública nos dias de hoje.

Na obra Paideía, a formação do homem grego, Werner Jaeger chama a atenção para o fato de que, com a invenção da cidade-estado grega (polis) o homem recebera "além de sua vida privada, uma espécie de segunda vida, o seu bios politikos. Agora, cada cidadão pertence a duas ordens de existência; e há uma nítida diferença em sua vida entre aquilo que lhe é próprio (idion) e o que é comum (koinon)" (JAEGER, 1995, III: 111). A capacidade humana de organização política, segundo o pensamento grego, ressalta Arendt inspirada na observação de Jaeger, encontra-se em oposição direta, e é diferente, da associação natural imposta a nós pelas necessidades da vida biológica e cujo centro é o lar (oikia) e a família.

A compreensão do sentido de tal distinção no mundo antigo passa a ser fundamental para compreendermos a noção de mundo comum, pois é no ambiente comum, propício à experiência de uma vida boa plena, como diziam os gregos antigos, que temos a possibilidade de manifestar algum tipo de cuidado com o mundo - que pode ser traduzido especialmente na experiência da atividade e da participação política - por intermédio da ação e do discurso e que se distingue de alguma maneira das atividades realizadas em atenção a interesses privados, pessoais ou de pequenos grupos. $\mathrm{O}$ desaparecimento na esfera social dessa distinção entre vida privada e vida política em tempos modernos parece ser um dos fatores mais importantes que marcam a nossa crise no mundo apresentando-se como um dos desafios a serem enfrentados. A dissolução dessa fronteira é um dado da atualidade. Então, como encaramos esse dado de nossa realidade, inclusive no que diz respeito ao sentido da educação em nossos dias?

Tomando a experiência da noção de uma vida boa no mundo grego, que nos serve como exemplo para pensarmos a nossa realidade no mundo atual, a fundação da polis representou para eles, em termos políticos e comuns, a possibilidade de um viver entre os homens na esfera pública (em ação e em discurso), de uma diferenciação entre aquilo que é necessário e útil à vida privada (primeira vida) e àquilo que fora constituinte do que Aristóteles chamava de bios politikos, (uma espécie de segundo nascimento), para a vida política, isto é, para o mundo comum em ação e discurso ${ }^{37}$, uma diferenciação que se torna

${ }^{37}$ Como observa Arendt: “a ação (práxis) e o discurso (lexis), das quais surge o domínio dos assuntos humanos (ta ton anthropon pragmata, como chamava Platão), de onde está estritamente excluído tudo o que é apenas necessário ou útil" (ARENDT, 2010: 29). 
cada vez mais difícil de ser apercebida nos assuntos humanos do mundo moderno e da vida pública e política atual, mas que deve ser levada em conta quando refletimos sobre a importância e o sentido de tal vida. Por isso mesmo deve ser trazida à tona em nossas discussões no presente e, especialmente, nas reflexões e diálogos sobre algum tipo de formação humana para o viver entre os homens, inclusive quando o assunto é educar em direitos humanos. Nessa perspectiva, a educação pode contribuir significativamente para o movimento de escolha com quem vamos no mundo e mesmo de ressaltar o sentido e a importância do viver junto como algo que é bom para estar em nossa companhia, seguir conosco no mundo e contribuir para que não corramos o risco de responder "ninguém" à pergunta "quem somos?" e "com ninguém" à indagação sobre "com quem escolhemos seguir no mundo?"

Em consonância com o pensamento de Jean Pierre Vernant sobre as origens do pensamento político antigo, Arendt realça a ideia de que a ação e o discurso, enquanto capacidades humanas das mais altas entre os gregos, já estavam presentes no pensamento pré-socrático $^{38}$. O discurso e a ação eram tidos pelos gregos como iguais, de mesma origem, categoria, espécie. Como vimos, o termo grego logos demonstra bem essa proximidade e o sentido que isso representava na experiência de um viver comum na polis. Daí para os antigos as ações políticas serem realizadas por intermédio de feitos e palavras, instrumentos comuns, estes permanecendo fora da esfera da necessidade e da violência, no âmbito da vida pública, espaço do conflito, do debate contraditório. $\mathrm{O}$ ato de encontrar as palavras certas no momento certo constituía entre os gregos, exemplarmente, uma ação passível de ser realizada tão somente no ambiente comum, palco das aparências e das singularidades humanas, no qual permanecem vivas nossas heranças, significações compartilhadas, valores, tradições, histórias.

Arendt chama a nossa atenção para o fato de que na experiência da polis,

e mais ainda na filosofia política que dela surgiu, a ação e o discurso separaram-se e se tornaram atividades cada vez mais independentes. A ênfase passou da ação para o discurso, e para o discurso como meio de persuasão e não como a forma especificamente humana de responder, replicar e estar à altura do que aconteceu ou do que foi feito. Ser político, viver em uma polis, significava que tudo era decidido mediante palavras e

${ }^{38}$ Inspirada em trechos da Ilíada de Homero observa que "a estatura do Aquiles homérico só pode ser compreendida quando se o vê como "realizador de grandes feitos e o pronunciador de grandes palavras"” (ARENDT, 2010: 30). 
persuasão, e não força e violência. Para os gregos, forçar pessoas mediante violência, ordenar ao invés de persuadir, eram modos prépolíticos de lidar com as pessoas, típicos da vida fora da polis, característicos do lar e da vida em família, em que o chefe da casa imperava com poderes incontestes e despóticos, ou da vida nos impérios bárbaros da Ásia, cujo despotismo era frequentemente comparado à organização doméstica (ARENDT, 2010: 32).

Formulando a opinião corrente da polis sobre o homem e sobre o modo de vida político na cidade-estado, Aristóteles constata, segundo Arendt, que viver fora da polis representava ser destituído "naturalmente, não da faculdade do discurso, mas de um modo de vida no qual o discurso e somente o discurso tinha sentido e no qual a preocupação central de todos os cidadãos era falar uns com os outros" (idem). Desta maneira, o viver bem de Aristóteles não se relacionava, e mesmo se opunha, à associação natural vivida no lar, visto que a esfera política e o governo absoluto de um chefe de família na vida doméstica eram mutuamente excludentes ${ }^{39}$.

No espaço da polis, cosmos humano organizado por via da política, cujo instrumento comum era a linguagem, havia uma decisiva distinção entre as esferas da vida privada e os domínios da família que diziam respeito à vida no lar, por um lado, e aos domínios da política que correspondiam à esfera da vida pública, por outro. Os domínios públicos da polis diziam respeito à política, enquanto que a esfera do lar, da família, da vida privada relacionava-se à economia doméstica (oikia). $\mathrm{O}$ antigo pensamento político via como axiomática e evidente por si mesma tal divisão entre as atividades relativas a um mundo comum na esfera da polis e as atividades relativas à manutenção da vida na esfera do lar.

Fica claro, então, que entre os antigos tudo o que dizia respeito ao econômico relacionava-se com a manutenção do ciclo vital, isto é, com os assuntos da vida doméstica por definição, e não da vida política, do domínio público, do mundo comum. Em nossos dias, ao vivermos numa esfera social que mistura tais domínios, ouvir tais palavras soa estranho. Por isso, como pensarmos hoje numa distinção entre o que diz respeito ao econômico e o que se relaciona a vida pública, política? Atualmente, os domínios do

\footnotetext{
${ }^{39}$ Philía: amizade, respeito mútuo. Um dos exemplos mais emblemáticos e conhecidos desse viver bem na esfera da vida comum entre os gregos antigos fora Sócrates, figura que nos serve de exemplo de um viver nessa espécie de segunda vida, a vida política. Seu julgamento perante o tribunal ateniense também o é, inclusive no que se refere aos limites que lhe são impostos pelo tribunal. O que já aponta problemas na própria sociedade ateniense.
} 
público e do privado parecem absolutamente indissociáveis, inseparáveis, sem levar em conta mais especificamente o que se refere a uma distinção entre os interesses privados e públicos, isto é, algo praticamente impossível de se realizar, o que acaba por comprometer a possibilidade de vivenciarmos uma autêntica experiência no âmbito da vida política e democrática.

Para Arendt, distintamente das obras, ditos e feitos realizados no âmbito da vida pública, o trabalho (labor) apresenta-se como o elemento da condição de vivente, bem como fenômeno do mundo privado que se relaciona com as carências e as necessidades do ciclo vital da espécie, e não da vida política, como parece ser a regra em nossos dias. Não por menos, Arendt chama a nossa atenção em A condição humana para a vitória do animal laborans em tempos modernos numa sociedade de consumidores. Não apenas a vitória do animal laborans, como também um grande menosprezo, desmerecimento pela vida pública e política que parece não fazer mais sentido algum. A rua de mão única de nossas sociedades, como já realçara Walter Benjamin (1987), atendem predominantemente ao consumo parecendo indicar que temos apenas uma opção a seguir, trafegar ou navegar em direção ao consumo e pela manutenção da vida. E nossas ruas de fato parecem traduzir essa ideia, seguir numa única direção, a de circular mercadorias e consumidores numa sociedade que atende apenas às necessidades de sobrevivência da espécie, ou seja, o consumo do mundo.

Primordialmente como fenômeno pré-político, característico da organização do lar e da manutenção do ciclo vital da espécie, as carências e as necessidades humanas compeliam os homens a viver juntos na esfera do privado ${ }^{40}$. Na comunidade natural do lar que nascia da necessidade, destaca Arendt com base no pensamento antigo, e distintamente do "estado de natureza" que aparecerá no pensamento político hobbesiano do século XVII, a força e a violência eram justificadas por serem os únicos meios de se vencer a necessidade,

uma vez que todos os seres humanos são sujeitos à necessidade, têm o direito de empregar a força e a violência contra os outros; a violência é o ato pré-político de liberar-se da necessidade da vida para conquistar a liberdade do mundo. Essa liberdade é a condição essencial daquilo que os gregos chamavam de felicidade, eudaimonia, que era um estado objetivo dependente, em primeiro lugar, de riqueza e de saúde (ARENDT, 2010: 37).

40 "A comunidade natural do lar nascia da necessidade, e a necessidade governava todas as atividades realizadas nela" (ARENDT, 2010: 36). 
E que como vimos, segundo Aristóteles, tem possibilidades de se realizar no âmbito de uma autossuficiência do tipo comunal (e não solitária).

Contrariamente a esfera privada - pré-política - onde o que predominava era a desigualdade que aprisiona a necessidade e onde a liberdade não existe, o domínio da polis correspondia à esfera da liberdade - veremos um pouco mais adiante a noção de liberdade no âmbito da vida política - a vitória sobre as necessidades da vida no lar estabelecia a condição certa para a liberdade na vida pública. A liberdade entre os gregos realizava-se em tal espaço, entre iguais, e cujo instrumento comum era a linguagem: "Ser livre significava ao mesmo tempo não estar sujeito às necessidades da vida nem ao comando de outro e também não comandar. Significava nem governar nem ser governado" (ARENDT, 2010: 39). Entre os gregos, a igualdade "era a própria essência da liberdade: ser livre significava ser isento da desigualdade presente no ato de governar e mover-se em uma esfera na qual não existiam governar nem ser governado" (ARENDT, 2010: 39).

No mundo antigo havia um abismo entre as esferas privada e pública que diariamente os gregos transpunham a fim de transcender o estreito domínio do privado e “ascender" ao domínio do público, do político, no qual a liberdade aparecia em feitos e em palavras realizadas num ambiente fecundo ao debate contraditório - o franco falar a coragem da verdade ${ }^{41}$ - onde não havia comandantes nem comandados, mas tão somente seres livres e iguais. Transpor esse abismo que existia entre a vida protegida no ambiente privado e a impiedosa exposição na polis representava estar de posse de uma das atitudes políticas mais elementares do mundo antigo, a virtude da coragem (ARENDT, 2010).

Como observa Arendt,

deixar o lar, originalmente para abraçar alguma empresa aventureira e gloriosa, e mais tarde simplesmente para dedicar a vida aos assuntos da cidade, exigia coragem, pois era só no lar que os indivíduos se preocupavam basicamente em defender a vida e a sobrevivência próprias. Quem ingressasse no domínio político deveria, em primeiro lugar, estar disposto a arriscar a própria vida; o excessivo amor à vida era um obstáculo à liberdade e sinal inconfundível de servilismo. A coragem, portanto, tornou-se a virtude política por excelência, e só aqueles que a possuíam podiam ser admitidos em uma associação que era política em conteúdo e propósito e que por isso mesmo transcendia o mero estar junto imposto igualmente a todos - escravos, bárbaros, gregos - pelas premências da vida (2010: 44).

${ }^{41}$ FOUCAULT, Michel. O governo de si e dos outros: curso no Collège de France (1982-1983). Tradução Eduardo Brandão. São Paulo: Editora WMF Martins Fontes. 2010. 
Em tal contexto, o aprendizado, a educação vai apresentar-se como uma formação humana para a vida boa, a liberdade e o exercício da igualdade num ambiente propicio ao viver comum e à melhor vida humana.

Arendt observa que na raiz da consciência política grega podemos encontrar uma clareza e uma precisão sem-par na definição da diferença entre a vida, cuja finalidade consistia na garantia de seu sustento, na manutenção do processo vital, e a vida na esfera política. A vida do cidadão que ingressava no domínio da política era nomeada por Aristóteles como sendo a vida boa, uma espécie de segunda vida que possuía qualidade inteiramente diferente da vida ordinária, era melhor, livre de cuidados, mais nobre e boa justamente por deixar de ser limitada ao processo biológico: livre do trabalho, da obra e do anseio inato de sobrevivência comum a todas as criaturas vivas (ARENDT, 2010).

A política entre os antigos não existia em função da vida econômica, mas contrariamente, no que se refere aos membros da polis, é a vida no lar que vai existir em função da vida boa dos homens públicos na cidade-estado, domínio comum. Algo que vai se constituindo na cultura dos gregos antigos como formação humana para a vida comum que realça em certa medida o papel e a importância da pluralidade humana como condição de toda vida política. Em suas reflexões sobre a política, percebemos que Arendt ressalta tal ideia apresentando uma preocupação fundamentalmente relacionada à questão da pluralidade humana, vista como a condição prévia e como a razão de ser da vida política.

Já no início do primeiro capítulo de A condição humana, Arendt realça que a pluralidade humana apresenta-se como a condição sine qua non e per quam de toda vida política, havendo uma relação especial entre a ação, o discurso e a vida em comum, pois o homem não pode viver fora da companhia dos outros homens, incluindo tal condição entre as características especificamente humanas que a ela pode proporcionar dignidade. Os homens só se inserem no mundo por atos e palavras que são uma espécie de segundo nascimento, que confirma e assume o aparecimento físico original e que radica a política na liberdade humana de realizar ações e discursos capazes de promover as nossas histórias no palco das aparências que é o espaço público, locus da pluralidade humana, no sentido aristotélico, lugar da vida boa e, como observara Nussbaum (2009) em atenção aos ensinamentos deste, da melhor vida humana numa autossuficiência de tipo comunal.

A noção de mundo comum em Arendt, ligada como é a vida política, delineia-se de forma bastante aproximada da experiência da polis grega. O mundo comum como artifício 
humano é o espaço das aparências criado pelos homens, o espaço do "entre nós", lugar da visibilidade e da publicidade no qual são públicos atos e palavras, a esfera na qual aparecem singularidades que são vistas e ouvidas na sua diversidade e pluralidade, e que assim são constitutivas de um mundo humano (conflito) no qual a liberdade pode ser tratada como signo da ação humana oriunda das relações mundanas.

É o espaço público em que a pluralidade humana se apresenta como condição fundamental para a efetiva possibilidade da realização de ações e discursos reveladores da singularidade e da espontaneidade dos seres e garantidores da conservação de um mundo compartilhado. A política surge nesse espaço do "entre nós", estabelecendo-se, portanto, como uma relação entre os homens no mundo compartilhado, onde não há descomedimento, violência, destruição, mas sim diálogo, debate, persuasão, publicidade, igualdade, liberdade, vida boa. Ao que parece ser o mundo pelo qual o educador assume a responsabilidade, apresentando-o aos novos, inserindo-lhes nele. E assim o faz por amor ao mundo (Amor Mundi) e por cuidado com ele.

Hannah Arendt considera que a vida humana tem raízes permanentes num mundo, como artifício humano, em que a condição humana, a vita activa (o trabalho, a fabricação e a ação) ${ }^{42}$ se empenha ativamente em fazer algo. O trabalho, a fabricação e a ação, e as suas respectivas condições, vida, mundanidade e pluralidade estão intimamente ligadas com as condições mais gerais da existência humana, isto é, o nascimento e a morte, a natalidade e a mortalidade. $\mathrm{O}$ trabalho (labor) assegura a vida da espécie. A fabricação e o seu produto (artefato humano) emprestam certa permanência e durabilidade ao mundo humano. E a ação cria as condições para a lembrança (a história). Para ela, das três atividades, "a ação tem a relação mais estreita com a condição humana da natalidade; o novo começo inerente ao nascimento pode fazer-se sentir no mundo somente porque o recém-chegado possui a capacidade de iniciar algo novo, isto é, de agir" (ARENDT, 2012: 10). Como veremos mais adiante, a educação como formação humana dialoga de certa maneira com esse recém-chegado que tem a capacidade de iniciar algo novo, imprevisto, revolucionário. A ação, como algo novo, inusitado, advém justamente de tal condição humana da natalidade, apresentando-se esta condição como algo fundamental não apenas à pluralidade humana e à vida política, mas também essencial à própria educação.

\footnotetext{
${ }^{42}$ Na primeira tradução de A condição humana temos: labor, trabalho e ação. ARENDT, H. A condição humana. Tradução de Roberto Raposo. Posfácio de Celso Lafer. 10ª . Edição. Editora Forense Universitária. Rio de Janeiro. 2008.
} 
A ação realiza-se no palco das aparências que é o mundo comum, sendo considerada a atividade política por excelência e, juntamente com a natalidade, constitui-se como a categoria central do pensamento político arendtiano, sem as quais não há que se falar em pluralidade humana tampouco em mundo comum. A ação, a mais importante das experiências políticas, possibilita o iniciar de algo novo, nas palavras de Adriano Correia,

cada ação afirma a singularidade do agente, mas ao mesmo tempo reafirma as condições humanas da natalidade e da pluralidade. Se concebermos a ação como o começo que deflagra uma nova série de eventos, mas que não pode ser deduzido de eventos precedentes compreenderemos porque a pluralidade contida no nascimento é a condição prévia (conditio sine qua non) da vida política e também porque a pluralidade, reafirmada em cada ação, é a própria razão de ser (conditio per quam) da política (CORREIA, 2008: 30).

A vida humana só é possível num mundo em que os seres humanos testemunhem uns a presença dos outros e todas as atividades humanas são condicionadas pelo fato de que os homens vivem juntos, "mas a ação é a única que não pode sequer ser imaginada fora da sociedade dos homens" (ARENDT, 2010: 26). Só a ação depende inteiramente da constante presença de outros e o "milagre" da ação, segundo Arendt, está ontologicamente enraizado na humanidade como pluralidade de inícios singulares. É somente na estrutura da organização política que os homens não apenas vivem, mas agem juntos. É no domínio da vida estritamente política que o homem tem a capacidade de agir, "e de agir em conjunto e em concerto" (ARENDT, 2010: 152) no espaço-entre os homens, denominado mundo comum.

Como vimos ressaltando, recorrendo aos ensinamentos dos antigos, em especial Aristóteles, Arendt considera a ação e o discurso como atividades políticas e constituintes do que era denominado bios politikos. A ação e o discurso são atividades fundamentais e presentes nas comunidades humanas sem as quais o mundo comum não é possível. Entretanto, não há possibilidade de construção de um mundo compartilhado onde não haja convivência, onde não se reconheça a diversidade, a pluralidade, o outro. Os feitos, os ditos e os lembrados constituem o mundo comum, um artificialismo humano, no qual a pluralidade humana, a diversidade, o reconhecimento da importância do outro, são condições para que isso ocorra por intermédio da vida pública, lugar no qual aparecemos. Agir e falar são manifestações externas da vida humana que só se realizam neste espaço 
comum - palco das aparências - onde a pluralidade humana é algo imprescindível para o aparecimento da singularidade humana (alguém) e da identidade do ser (político) que livremente pode se ajustar a um mundo compartilhado e comum.

Em Que é liberdade? Arendt propõe-se a realizar aquilo que, segundo ela mesma, parece ser uma empresa irrealizável: definir o sentido do que é a liberdade. Segundo Arendt, o problema da liberdade é crucial para as questões que dizem respeito à política e por extensão ao próprio mundo. Assim, não se exime de discutir tal questão. Em suas reflexões nas diversas obras que escreveu, Arendt apresenta Sócrates como figura central e exemplar da enunciação dessa questão. E isso nos interessa, pois o fenômeno da liberdade aparece não na esfera do pensamento, mas no âmbito da política e dos problemas humanos em geral, isto é, no mundo. O campo original da liberdade relaciona-se com o âmbito mundano, da vida pública e dos assuntos humanos.

Lembrando as experiências do mundo antigo, relaciona-se com a política, com o universo espiritual da polis. Segundo Arendt, "o campo em que a liberdade sempre foi conhecida, não como um problema, é claro, mas como um fato da vida cotidiana, é o âmbito da política" (1990: 191). Neste sentido, quando falamos de liberdade, falamos também do problema da política, da ação, "pois ação e política, entre todas as capacidades e potencialidades da vida humana, são as únicas coisas que não poderíamos sequer conceber sem ao menos admitir a existência da liberdade, e é difícil tocar em um problema político particular sem, implícita ou explicitamente, tocar em um problema de liberdade humana" (1990: 192).

É inconcebível pensarmos em ação e política sem admitirmos a existência de referida liberdade que aparece, em Arendt, como distinta da "liberdade interior". A liberdade é o sentido das nossas experiências humanas no mundo que nos permite, por assim dizer, conceber a vida política, a ação humana e o próprio cuidado com o mundo comum. E o que nos dá o sentido dessa liberdade é justamente a sua compreensão. Em poucas palavras, a liberdade constitui-se como a razão de ser da política e seu domínio de experiência é a ação. Historicamente, segundo Arendt, o declínio da liberdade como fenômeno essencialmente político se deu no fim do Império Romano, justamente quando temos uma separação entre a interioridade e o mundo, um distanciamento entre a política e a liberdade que ruma para a interioridade e se desprende do mundo. 
Ao realizarmos esse recuo histórico, genealógico, percebemos que, de acordo com o entendimento dos antigos, o homem só poderia ser livre se, libertado das necessidades da vida, não apenas possuísse um lugar (lar) no mundo, mas agisse entre os iguais, rompendo com a mera reprodução e iniciando algo novo. A condição de estar livre delineava-se nas relações mundanas, na vida comum, sendo experimentada como uma realidade mundanamente tangível. A nossa consciência da liberdade foi tomada inicialmente em nosso relacionamento com os outros (e não introspectivamente com nós mesmos), "antes que se tornasse um atributo do pensamento ou uma qualidade da vontade, a liberdade era entendida como o estado do homem livre, que o capacitava a se mover, a se afastar de casa, a sair para o mundo e a se encontrar com outras pessoas em palavras e ações" (ARENDT, 1990: 194).

A figura de Sócrates serve-nos de exemplo desse tipo de liberdade, ou melhor, é exemplar desse estado do homem livre que se afasta de casa, sai para o mundo, encontra-se com outras pessoas. No filme Sócrates de Roberto Rossellini, temos diversas cenas que representam esse estado do homem livre, especialmente no que se refere ao seu julgamento perante o tribunal ateniense. Entretanto, vale ressaltar uma cena que é bastante peculiar: Sócrates sai para buscar algo de comer para a sua família e volta somente alguns dias depois. Saiu para o mundo e encontrou-se com outras pessoas em palavras e ações oriundas de tais relações mundanas (estado do homem livre) no mundo comum. Daí o exemplo de Sócrates ser tão instigante de ser pensado em nosso presente, onde isso se torna cada vez mais difícil de ser realizado, além de ser extremamente recorrente e mesmo inspirador no pensamento arendtiano sobre o assunto no qual temos nos debruçado. E que nos inspira a pensarmos na possibilidade desse aparecer livremente como alguém no mundo.

A companhia de outros homens nas mesmas condições e o espaço público comum para a realização de tais encontros eram condições indispensáveis para que a liberdade aparecesse como uma realidade concreta, tangível por feitos e palavras, delineada no mundo politicamente organizado da cidade-Estado. O âmbito público era considerado o espaço concreto onde a liberdade tinha a possibilidade de aparecer. Neste sentido, a liberdade e a política coincidiam, sendo "relacionadas uma à outra como dois lados da mesma matéria" (ARENDT, 1990: 195). 
Desta maneira Arendt reflete sobre aquilo que ela denominou ser um velho truísmo - certamente com suas origens no mundo antigo - ao afirmar que a razão de ser da política é a liberdade e que esta é vivida basicamente na ação. Pensando sobre isso, não vê a liberdade como um fenômeno da vontade ou do intelecto, mas sim como fenômeno da ação que brota de princípios que oriundos das relações mundanas inspiram do exterior. Em poucas palavras e de uma maneira quase poética, para não dizer que é totalmente, vê a liberdade brotar do mundo comum como fenômeno da ação, engendrar seres humanos ao invés de criá-los à nossa própria imagem. O juízo do intelecto pode preceder a ação, a vontade inicia-a, mas "o princípio inspirador torna-se plenamente manifesto somente no próprio ato realizador" (ARENDT, 1990: 199), assim, na interface da ação com o mundo no qual ela aparece. Neste sentido podemos afirmar que a ação brota como que inspirada do mundo e os homens são livres enquanto agem na vida pública "nem antes, nem depois; pois ser livre e agir são uma mesma coisa" (idem).

$\mathrm{Na}$ Antiguidade grega e na romana, a liberdade aparecia na polis como um conceito político. No modo político de vida - bios politikós - a liberdade vivenciada no processo de ação aparecia como a ideia central da política, distintamente do modo de vida escolhido pelo filósofo, apartado do mundo público. É imprescindível relembrar as experiências da Antiguidade grega e romana para se falar de política e de seus princípios

pela simples razão de que nunca, seja antes ou depois, os homens tiveram em tão alta consideração a atividade política e atribuíram tamanha dignidade a seu âmbito. Quanto à relação entre liberdade e política, existe a razão adicional de que somente as comunidades políticas antigas foram fundadas com o propósito expresso de servir aos livres - aqueles que não eram escravos, sujeitos a coerção por outrem, nem trabalhadores sujeitados pelas necessidades da vida (ARENDT, 1990: 201).

A razão de ser do político no sentido da polis era o estabelecimento e manutenção de um espaço em que a liberdade enquanto virtuosismo pudesse aparecer. Tudo que ocorre nesse palco das aparências é político. A liberdade é um atributo da ação e constitui uma realidade concreta neste âmbito, no qual tudo que aparece é político por definição: feitos, palavras, eventos - são comentados, relembrados, transformados em estórias e de certa maneira imortalizados. 
Arendt relembra antigas metáforas utilizadas pelos gregos, tais como tocar flauta, dançar e navegar para ilustrar as diferenças entre as atividades políticas e as demais atividades. Nas artes assim como nas atividades políticas o virtuosismo do desempenho é decisivo. Virtuosidade é "uma excelência que atribuímos às artes de realização (à diferença das artes criativas de fabricação), onde a perfeição está no próprio desempenho e não em um produto final que sobrevive à atividade que a trouxe ao mundo e dela se torna independente" (ARENDT, 1990: 199). E nos apresenta outra metáfora que aproxima a política da arte: na medida em que cada ação contém um elemento de virtuosidade e, sendo o virtuosismo a excelência que podemos atribuir à prática das artes, a política tem sido com frequência metaforicamente definida como uma arte na qual o virtuosismo de seu desempenho é decisivo. Mais especificamente as denominadas artes de realização que, para a autora, têm grande afinidade com a política, "os artistas executantes - dançarinos, atores, músicos e o que o valha - precisam de uma audiência para mostrar seu virtuosismo, do mesmo modo como os homens que agem necessitam da presença de outros ante os quais possam aparecer; ambos requerem um espaço publicamente organizado para sua “obra”, e ambos dependem de outros para o desempenho em si” (ARENDT, 1990: 201).

Arendt descreve a polis grega como a forma de governo que proporcionou um espaço público para o aparecimento dos homens, um lugar onde pudessem agir e a liberdade pudesse aparecer numa espécie de anfiteatro, palco de nossas aparições, livres e iguais, no qual por intermédio da ação e do discurso temos possibilidade de, quem sabe, responder à pergunta Quem somos? Singularmente, alguém que brota como que inspirado do mundo comum. E aparece. Mas para que isso ocorra dependeremos fundamentalmente do virtuosismo do nosso desempenho em realizá-lo por nós mesmos. Eis a questão. Daí a nossa escolha por caminharmos com Arendt dialogando sobre o assunto. E a partir disso refletirmos em nosso presente especialmente sobre quem somos e com quem escolhemos seguir no mundo entre coisas, pessoas e pensamentos. 


\title{
4. COM QUEM VAMOS NO MUNDO?
}

\author{
"Em vez de engendrar um ser humano, tentamos \\ criar o homem à nossa própria imagem."
}

Hannah Arendt

Em sua manifesta e permanente insuficiência, a compreensão da importância de se buscar incessantemente algum sentido à experiência humana na vida política, que não abole o atributo básico da pluralidade humana ${ }^{43}$, e de vivermos bem num lugar onde possamos compartilhar um mundo comum de significações, realizações, reconhecimentos e singularidades em nossas travessias numa condição humana muitas vezes ambígua e paradoxal que nos leva a indagar quem somos e a refletir sobre nossas escolhas no presente entre o nosso passado e o nosso futuro, tais como, por exemplo, sobre o sentido de alguma coisa e de alguém diante da moderna expansão do nada e do ninguém, que muitas vezes nos obriga a realizar algum tipo de recuo histórico, genealógico, para tentar dar conta do nosso presente ${ }^{44}$.

E de alguma maneira dialogar com a compreensão do sentido, do papel e da importância da educação, como formação humana para a vida pública e política, que de certa forma pode nos orientar nesse trajeto de escolher com quem vamos (nossas

\footnotetext{
43 "Em termos prático-políticos, porém, a profunda importância da família repousa sobre o fato de estar o mundo organizado de tal modo que não há nele lugar para o indivíduo, ou seja, para quem quer que seja diferente. As famílias são fundadas como abrigos, poderosas fortalezas num mundo inóspito e estranho no qual queremos introduzir o parentesco. Este desejo conduz à perversão fundamental da política, porque abole o atributo básico da pluralidade, ou melhor, confisca-a pela introdução do conceito de parentesco." $A$ promessa da política/ Hannah Arendt; organização e introdução de Jerome Kohn. Difel, 2008, p. 145/146.

${ }^{44} \mathrm{E}$ nossas inquietações, dúvidas, angústias do presente que diariamente sentimos em nossa caminhada e a partir de nossas escolhas: nas pessoas, nas ruas, nas escolas, nas comunidades, em fatos e relatos, naquilo que aconteceu e que acontece na vida pública e no cenário político atual, em nossos bairros, cidades, estados, e não apenas no Brasil, mas em diversos lugares do mundo: a não distinção entre o público e o privado, corrupções, violências, guerras. E Arendt nos alerta com base em suas experiências vivenciadas no século passado para o fato de que "pode-se admitir como uma regra geral neste século que qualquer coisa que seja possível em um país pode, em futuro previsível, ser igualmente possível em praticamente qualquer outro país." Hannah Arendt, Entre o passado e o futuro, São Paulo, Perspectiva, 2007, A crise na educação, página 222.
} 
companhias) no mundo em face de nossa humana condição, em certa medida precedendo tal experiência no âmbito da vida política (assumindo a responsabilidade por ela) - e por assim dizer esticar esteiras para que o outro possa passar - parece ser por alguns aspectos o cerne de nossa reflexão que irá nos levar, finalmente, a pensar a educação em direitos humanos como um possível caminho a ser trilhado nesse sentido. Em nosso mundo e em nossas experiências compartilhadas no âmbito daquilo que nos é comum que passado escolhemos para transmitir aos mais novos? Qual é a herança?

No caminho da possibilidade de resistência, transformação ou mesmo preservação de um mundo comum, traços constitutivos do desconforto que nos gera paradoxalmente a trágica condição humana e o próprio aprendizado que dela decorre, que podem contribuir para um diálogo e para uma proposta concreta de intervir no debate público, especialmente como formação para a vida pública e política. Lembrando-se do exemplo deixado pelos gregos antigos, especialmente Aristóteles, de uma autossuficiência mais do tipo comunal (não solitária) e dialógica, de uma emancipação (sem querer cometer anacronismos) ou mesmo de um gosto pela liberdade no âmbito da vida boa, de participação política na vida pública que passa por uma formação humana que a precede, preservando-a, mas também a transformando. O que em certa medida tem haver com as nossas escolhas e, por exemplo, com o passado ao qual nos ligamos, ou não, em termos de uma formação humana em nosso presente.

Engendrar seres humanos, singularmente, ao invés de tentar criá-los à nossa própria imagem. Em suma: educação e vida política. E o que isso tem haver com a dimensão ética da palavra e com a inserção dos novos num mundo comum que os precede e que nos foi legado numa herança sem testamento? ${ }^{45}$ Noutras palavras: natalidade e pluralidade

$45 \mathrm{O}$ pensamento de Hannah Arendt permite que surja novamente para nós, como ressalta Antonio Abranches, "no frescor da própria origem, um sentido que o "turbilhão de familiaridades" já havia sepultado. Esse retorno à origem só é possível porque a grande tradição do pensamento ocidental, que durante muitos séculos religou passado e futuro, provendo a memória e a expectativa, se exauriu, legando-nos uma herança sem testamento, sem nenhuma recomendação de como pode ou deve ser usada. O fim da tradição, um fim de muitos nomes, é um fato no mundo e, como tal, não está sujeito à deliberação pessoal." No prefácio geral de As Origens do Totalitarismo Arendt considera que "já não podemos dar-nos ao luxo de extrair aquilo que foi bom no passado, simplesmente chamá-lo de nossa herança, deixar de lado o que foi mau e simplesmente considerá-lo um peso morto, que o tempo por si mesmo relegará ao esquecimento. A corrente subterrânea da história ocidental veio à luz e usurpou a dignidade de nossa tradição. Esta é a realidade em que vivemos. É por isso que são inúteis todos os esforços de escapar do horror do presente, refugiando-se na nostalgia por um passado ainda eventualmente intacto ou no esquecimento antecipado de um futuro melhor." Em tais circunstâncias, observa Abranches, "o pior que nos poderia acontecer seria confundir o fim da tradição com o fim do passado, o que equivale a considerar o passado como o que já passou." Hannah Arendt, A dignidade da política: ensaios e conferências; organizador Antônio Abranches - Rio de Janeiro, Relume-Dumará, 1993, Introdução - Uma herança sem testamento, páginas 9 e 10. 
humana, conceitos caros ao pensamento de Arendt não apenas no que se refere ao significado da política, mas também ao da própria educação, que nos apresentam verdadeiras pérolas a serem pescadas nesse trajeto que busca maximizar em última instância a importância de se engendrar seres humanos singulares. Não que necessariamente a educação e a política se misturem ou se confundam ${ }^{46}$, mas especialmente que a educação, e a figura do educador nesse movimento de escolher com quem vamos no mundo, e de apresentá-lo aos novos, inserindo-os nele, só podem assumir a responsabilidade por esse nosso mundo, dizendo o que ele é, na medida em que ele - o mundo humano - faz algum sentido a quem protagoniza tal papel de educador.

Em consonância com o pensamento de Arendt, especialmente em seu artigo que trata da crise na educação, que aparece em sua obra Entre o passado e o futuro, o que chama a nossa atenção é justamente a crise do mundo moderno refletida na educação. Em outras palavras, é a ausência de um mundo comum - expansão do nada e do ninguém refletida no âmbito da educação. Daí a dificuldade de se educar num mundo em crise. $\mathrm{O}$ que nos leva a pensar, inclusive sobre o sentido da educação e de nossas escolhas, de com quem seguirmos no mundo, quais serão as nossas companhias.

Educar em um mundo deserto, qual é a tarefa, a escolha, o papel que o educador assume diante disso? Como escolhermos com quem vamos no mundo num ambiente desértico, ou seja, na ausência de alguma coisa e de alguém com quem possamos caminhar? Noutras palavras, como escolhermos com quem vamos sem termos com quem ir? Diante de tal problemática a figura do professor parece assumir papel ainda mais importante, que envolve certa dose de coragem, criticidade e resistência em face do vivido a ser possivelmente transformado. E que, em larga medida, exige um esforço de compreensão sobre o que se passa e sobre o sentido do mundo a ser anunciado aos novos em face da responsabilidade que os mais velhos assumem pelo mundo comum. Daí a importância dos exemplos, a dimensão de profundidade e o mergulho nisso tudo em busca de pérolas, achados que contribuam em nossa trajetória compartilhada no presente entre o passado e o futuro.

\footnotetext{
${ }^{46}$ No início do seu artigo denominado A crise na educação, que está em sua obra Entre o passado e o futuro (1958), Arendt ressalta distinções entre as esferas da educação e da política, "a educação não pode desempenhar papel nenhum na política, pois na política lidamos com aqueles que já estão educados." Hannah Arendt, Entre o passado e o futuro, São Paulo, Perspectiva, 2007, A crise na educação, p. 225.
} 
E mesmo diante de tantas dificuldades, a incessante busca por atribuir sentido a tudo isso, sem o que não há o que assumir tampouco dizer ou mesmo realizar em profundidade. Se o que predomina é o nada e o ninguém, o que dizer aos novos sobre o mundo? E mais, em face de tal condição assumir a responsabilidade por que e por quem? Por nada nem ninguém? Um momento de crise que nos faz pensar não só no sentido de um mundo comum, como também no sentido educacional. E pensar sem corrimãos, como dizia Arendt que nos convida a refletir sobre o assunto, num momento crítico em que nos fora legado uma herança sem testamento.

Trata-se aqui de se pensar, dialogar, compreender, sobretudo o sentido da educação como formação humana para a vida pública e política. Mas como pensá-lo num mundo em crise? O que nos parece ser sucintamente um ato de resistência, coragem e por assim dizer amor ao mundo humano e comum em face da ameaça de sua destruição ou mesmo do seu desaparecimento. Recorrendo ao exemplo deixado pelos antigos que nos inspira a pensá-lo na atualidade, um gosto pela liberdade na vida pública e pelo bem viver, uma melhor vida humana, numa autossuficiência de tipo comunal, como diria Aristóteles, que não vê outra possibilidade de realização de tal empreitada a não ser no caminhar e viver junto, dialogando com o nosso passado e inserindo os novos por intermédio de uma formação humana num mundo comum que eles ainda não conhecem e para o qual irão nascer numa espécie de segundo nascimento para a vida boa, a vida pública.

Recorremos novamente a Arendt desta vez para realçar que tal liberdade se dá no âmbito da vida pública, e especialmente em relação ao passado, como possibilidade de se construir aquilo que é novo e, neste sentido, revolucionário. Como observa o Professor José Sérgio Fonseca de Carvalho, a liberdade para Hannah Arendt é liberdade em relação ao passado, como possibilidade da construção daquilo que é novo, revolucionário. É a ideia de natalidade, conceito central no pensamento de Arendt: o fato de que o homem é sempre o início (Agostinho), de que dele não sabemos qual será o futuro. Assim, o conceito de natalidade vai aparecer como sendo fundamental não apenas à possibilidade de realização de tal liberdade na esfera da vida pública, como também à essência e ao sentido da própria educação $^{47}$.

\footnotetext{
${ }^{47}$ Carvalho, José Sérgio Fonseca de. Documentário denominado Hannah Arendt e a educação. Coleção Filósofos e a Educação: Arendt. Produzido e distribuído por ATTA Mídia e Educação (2009).
} 
Ao analisar o pensamento de Arendt em respeito à educação, Carvalho chama a nossa atenção para o fato de que a educação é conservadora no sentido de que é por meio dela que nosso legado cultural permanece vivo, bem como para o fato de que um professor faz essa ligação entre um passado e um futuro trazendo essa herança que ele representa e que se renovará naqueles que podem representar o novo, o revolucionário. É este (o novo, o aluno) que poderá fazer tal herança continuar viva não repetindo, mas renovando, fazendo com que ela tenha novos sentidos. A educação terá, portanto, um papel conservador, dirá Arendt, em benefício daquilo que é novo e revolucionário, possibilitando-nos vivenciar essa experiência de dialogar com o nosso passado, daí a dimensão da profundidade (são tradições históricas que nos chegam e a educação mantendo este mundo).

Nesse trajeto de escolher com quem vamos no mundo, é como se a educação tivesse um compromisso para com este e por isso conservasse algo dele para que algo novo, imprevisto e inusitado tenha possibilidades de acontecer singularmente. Adriano Correia realça este significado político da natalidade (do novo) em Arendt, e mesmo em Agostinho, para que houvesse um início o homem foi criado, sem que antes dele ninguém o fosse. Aqui, a centralidade da relação do ser humano com o mundo desloca-se da mortalidade para o conceito de natalidade. O que nos dá a dimensão do novo ao significado do político, o nascimento "é a aparição inaugural de uma singularidade que, por sua unicidade e espontaneidade, é promessa de liberdade, que pode ganhar realidade no domínio político. Os homens, como entes do mundo, são politicamente não seres para a morte, mas permanentes afirmadores da singularidade que o nascimento inaugura" (CORREIA, 2008: 33).

Podemos identificar em Arendt, como ressalta Correia, um vínculo estreito entre a natalidade, a singularidade, a espontaneidade, a ação, a liberdade e a própria pluralidade humana "a novidade de cada nascimento conserva as infinitas possibilidades que renovam a promessa de perseverança da pluralidade entre os homens. Pela mesma razão, qualquer ruptura na relação entre natalidade e espontaneidade representa um risco que pode minar as possibilidades mais remotas da política" (CORREIA, 2008: 30). E não temos possibilidade de conceber uma comunidade política sem um mundo comum que simultaneamente separe e relacione os homens entre si. 
O mundo comum é sinônimo de vida política. Sem esta não há que se falar naquele. E sem o mundo comum a educação assumiria a responsabilidade pelo que? Diria o que, sobre o que? E para quem? Nada, ninguém? São questões que nos levam a pensar sobre a nossa condição humana, a vida, o mundo, as pessoas, as nossas escolhas, travessias, responsabilidades a serem assumidas, ou não, em nosso presente entre o nosso passado e o nosso futuro. E mesmo a querer compreender, por exemplo, por que Arendt insiste tanto em realçar a importância de se ligar à tradição do nosso pensamento político, especialmente da polis grega, concebendo como desejável a conservação da fronteira entre a natureza (zoé) e o mundo humano (biós).

Resistir ou se adaptar às modernas condições que insistem em negar sentido à vida política, ao mundo comum? Reconhecer ou não algum tipo de fronteira entre natureza e mundo, alguma distinção entre vida biológica e vida política? O que isso nos implica? Assumir ou não a responsabilidade pelo mundo comum? Dizer ou não o que ele é? São questões que em nossos dias batem constantemente a nossa porta e que nos levam a fazer escolhas e mesmo a trilhar caminhos: isolados ou comuns, esse é o ponto. É como se nossas escolhas desvelassem o juízo que temos sobre o mundo e sobre nós mesmos. E a educação nos possibilitasse vivenciar essa experiência de dialogar com o nosso passado. E escolher. É como se o papel que o educador assume não fosse outro senão desvelar tais julgamentos sobre o mundo ao assumir a responsabilidade por ele, especialmente no trajeto de escolher nossas companhias entre coisas, pessoas, pensamentos.

Ao educador talvez não haja outra opção a seguir a não ser ajustar-se a um mundo compartilhado e abrir-se a ele em reflexão e diálogo, consigo mesmo e com os outros, correspondendo ao seu apelo e cumprindo o seu papel de educar por amor e cuidado com o mundo e com as pessoas que nele convivem. A tarefa do educador parece não ter possibilidade de ser introspectiva e isolada do mundo a ponto de silenciar sobre as coisas dele e tratá-lo de maneira superficial, a não ser ao preço de destruir o sentido de sua tarefa. Esta não é a melhor escolha, seu papel a cumprir não é esse. Ao adentrar numa sala de aula, por exemplo, o educador assume tal tarefa (responsabilidade) que se realiza especialmente no dizer, no ajuizar, no escolher com quem vamos no mundo.

Não dá para imaginar uma aula sem um professor que de alguma forma diga algo sobre o mundo, sem alguém ajuizando sobre alguma coisa, tão somente com uma solitária introspecção que nada diz, julga, escolhe. O próprio ensino de uma língua já é um 
mergulho nisso, um juízo sendo realizado sobre algo no mundo, especialmente para os novos que nele se inserem. As escolhas por lecionar determinada disciplina ou conteúdo curricular específico também o são. Educar em direitos humanos, por exemplo, como uma formação para a vida pública e política certamente o é. São escolhas que nos indicam com quem vamos e para onde. A tantas coisas no mundo realizando dizeres, escolhas, juízos de forma errônea e prejudicial, que seria extremamente leviano negar - em termos não apenas de responsabilidade, mas também de autoridade - tal papel ao educador, tal tarefa à educação.

A esfera da educação parece ser o lugar no qual as pessoas devam assumir tal papel, tal compromisso, e ter a coragem de ir às profundezas, enfrentar a questão de refletir e dialogar sobre quais serão as nossas companhias mesmo em face de um mundo em crise que nos obriga a pensar sem corrimãos. Dialogar com o nosso passado e ajustar-se a um mundo compartilhado no presente, especialmente em tempos de crise no mundo, nos quais temos obscurecido o papel da autoridade, quando tal herança nos é legada sem testamento. E, quem sabe, pescar pérolas. Por exemplo, o que ouvir de um professor, enquanto aluno, sobre o nosso mundo, as nossas heranças, valores, tradições históricas? Ou mesmo, o que dizer enquanto professor aos nossos alunos que representam por assim dizer o novo se inserindo num mundo comum que os precede? E neste sentido, o que dizer da vida pública e política? Engendrar um ser humano ou criá-lo à nossa própria imagem? Noutros termos, a política ainda teria algum sentido? Ainda poderia ser considerada uma boa companhia para nós em nossa caminhada humana e terrestre em face de tantos horrores? O que dizer sobre isso? E qual a tarefa da educação diante de tais ou quais perspectivas? Que trajeto seguir? Reflexão. Diálogo. Escolha. Formação. Autoridade. Responsabilidade. Mundo. Palavras e sentidos a caminharem conosco numa formação humana para o mundo.

Em nosso presente, apesar de tantos acontecimentos contrários ${ }^{48}$, e recorrendo a companhia de Arendt, dentre outros, ainda vemos sentido na vida política como possibilidade da fruição de nossas liberdades e felicidade humana. Mesmo reconhecendo ser algo pouco provável, inusitado, inesperado: só por milagre, o milagre do novo ${ }^{49}$. $\mathrm{E}$

\footnotetext{
${ }^{48}$ No caso do Brasil, por exemplo, a experiência recente da ditadura militar. E mesmo em tempos mais atuais, as nossas experiências democráticas não apenas por aqui, mas também no cenário internacional: a vida pública e política têm atendido a quais interesses?

49 "O início deflagra algo novo e também imprevisível, que não pode ser deduzido de qualquer evento que o tenha precedido, nem operar na antecipação do futuro. Ele instaura uma ruptura na sequência da previsibilidade cotidiana, assim como na temporalidade que teve seu começo simultâneo ao começo do mundo. "O novo sempre aparece na forma de um milagre", do inesperado, diz Arendt." Adriano Correia - $O$
} 
insistimos em ressaltar a importância do viver junto como um valor humano de primeira grandeza no sentido de uma possível melhor vida humana, sem o qual fica difícil caminharmos junto humanamente, dignamente, autossuficientemente, igual e livremente, reconhecendo-se mutuamente como seres humanos singulares (alguém) capazes de deflagrar o novo no mundo. Esse é o nosso juízo.

E diante de tal escolha, como temos ressaltado, a formação humana assumi papel crucial no trajeto de escolher, primeiramente, que vamos com alguém (e não sem ninguém) e, em face disso, com quem vamos no mundo, quais serão as nossas companhias entre o passado e o futuro. Vamos com Arendt que assume, como observa Adriano Correia,

que o mundo só se torna um lugar habitável e a convivência suportável e desejável se assumirmos por amor ou gratidão a responsabilidade por ele e se por amizade e respeito interagirmos com nossos pares. Sem isto, o mundo converte-se em um deserto, como ela assinala na conclusão de $A s$ origens do totalitarismo. Em suma, é em uma vívida disposição para com o ser/estar no mundo e para com o ser/estar com os outros que se podem vislumbrar possibilidades menos sombrias para os nossos tempos. Ela lembra que os gregos davam àquela humanidade (humaneness) "que se alcança no diálogo da amizade o nome de philanthropia, 'amor ao homem', uma vez que se manifesta em uma disposição para partilhar o mundo com outros homens" (1968, p. 65). Mais ainda, diz Arendt, "o prazer, que é fundamentalmente a consciência mais intensa da realidade, surge de uma abertura apaixonada ao mundo, do amor ao mundo" (amor mundi) (1968, p. 6, grifos no original). É pelo amor que a Vontade diz sim ao mundo e aos homens. Com efeito, comenta Arendt, "não há maior afirmação de algo ou de alguém do que amar este algo ou alguém, isto é, do que dizer: quero que sejas - Amo: Volo ut sis" (1995, p. 263). O Amor mundi converte-se então em "quero que o mundo persista", e o amor aos homens em quero que persistam. A ação afirma o mundo. Ao agir, o indivíduo confirma o desejo de que o mundo e os outros persistam (CORREIA, 2008: 28).

Se não há sentido para vivenciarmos a experiência de um mundo comum, compartilhado, torna-se difícil vislumbrar algum sentido para a educação como uma formação humana para o viver bem. O que faz da natalidade e da pluralidade humana algo imprescindível à permanência e mesmo à imortalidade do mundo comum, conceitos fundamentais no pensamento arendtiano sobre a noção de tal mundo e mesmo sobre o sentido do educar. Para Arendt o conceito de natalidade é essencial à educação, como observa Sylvie Courtine-Denamy: "Educar por amor ao mundo: a permanência do mundo 
repousa, então, na natalidade, na renovação incessante das gerações, no nascimento de homens novos que tenham cuidado com o mundo. Ou seja, que sejam capazes de renová-lo através de sua ação, susceptíveis assim a dar início a algo novo" (2004: 181).

$\mathrm{O}$ ato de educar em certa medida precede a experiência no âmbito da vida política, pois sua tarefa fundamental como formação humana para a vida pública parece ser justamente apresentá-la aos novos que estão por se inserir nesse mundo, como algo que pode ser bom (de estar em nossa companhia), e mesmo indispensável para seguirmos trilhando no mundo com vistas a buscar uma melhor vida humana no viver junto, sob o risco de nos perdermos, como veremos mais adiante, num imenso deserto de solidão, introspecção, descrença e consumo do mundo. E mesmo de nos habituarmos a negar o mundo comum e a possibilidade de vivenciarmos um viver compartilhado de significações e realizações. A adaptação a tais condições pode representar uma ameaça de desaparecimento do mundo comum, predominando a ausência-de-mundo, isto é o nada e o ninguém (o deserto) sobre alguma coisa e alguém (o mundo comum).

Noutras palavras, a impressão que temos é que o viver bem parece ter suas possibilidades de realização atreladas à educação como uma formação humana para tal experiência compartilhada, fazendo disso uma escolha, um juízo daquilo que é bom e melhor para o ser humano e para o bem viver. Quais serão nossas escolhas? Que mundo escolhermos para nós vivermos? Ao refletirmos sobre a possibilidade de se realizar algum tipo de formação humana para a vida pública e política em nossos dias entendemos que, embora extremamente difícil ${ }^{50}$, em nossos tempos modernos de crise, esta última (vida política) ainda pode possuir algum significado para nós no presente, caso contrário, não pensaríamos em termos de uma formação para a vida pública em nossos dias. O que faria desse nosso trabalho algo sem sentido, sem razão de ser, inclusive e especialmente, no que tange à própria possibilidade de concebermos a educação em direitos humanos como uma formação para a vida comum em certo sentido nesse trajeto de escolher com quem vamos no mundo em nosso presente e de que mundo queremos para nós vivermos. Educar por amor ao mundo humano (a nós) e cuidado com o mundo (com nós).

Entendemos não haver outra opção. Tampouco outro caminho. E por que dizemos isso? Especialmente por entendermos não haver outro rumo possível para a humanidade no

${ }^{50}$ Cotidianamente presenciamos tantos acontecimentos, fatos, relatos, notícias sobre violência, corrupção, desvios de verbas públicas, descaso com a saúde pública, com a educação pública, com a política dentre tantas outras coisas. 
sentido de uma vivência comum que não passe por uma formação humana que a preceda, assuma a responsabilidade pelo mundo e diga o que ele é. E mais, sua presença ou ausência provavelmente terá, como vem tendo, uma parcela significativa de responsabilidade nos traços daquilo que serão os próximos passos da humanidade no futuro tanto no cenário nacional como no internacional.

Em suas obras, Ética e A afirmação histórica dos direitos humanos, o Professor Fabio Konder Comparato realça tal questão sob o enfoque de ressaltar que estamos diante de uma grande encruzilhada histórica na qual teremos que optar por um entre dois caminhos: um que se apoia na força militar, na dominação tecnológica e na concentração do poder econômico e outro que se funda na dignidade transcendente da pessoa humana. $\mathrm{Na}$ Parte III da obra Ética, que trata especificamente sobre o assunto, o autor nos sugere que o melhor caminho é o que se funda na dignidade transcendente da pessoa humana. Neste sentido, a educação em direitos humanos assume papel importante nesse trajeto de escolher com quem vamos e qual caminho seguir.

Caso contrário, qual seria o sentido de se educar na ausência de um mundo humano? Como escolher com quem vamos se não há ninguém para ir ou mesmo com quem ir? Parece-nos ser uma escolha movida por amor e cuidado com o mundo, é o melhor caminho a seguir. Essa é a escolha, seguir com alguém. Daí a importância de se atribuir sentido a tudo isso, reconhecendo como nos é crucial estarmos acompanhados por alguém no mundo e, em especial, de como escolhermos estar em boas companhias entre homens, coisas e pensamentos, realçando com isso o papel que a educação pode assumir neste sentido.

E isso nos remete inevitavelmente a outro momento da obra de Hannah Arendt no qual a autora reflete primordialmente sobre a arte e a política como fenômenos do mundo público e sobre a importância da escolha, do juízo, como algo que pode representar um compartilhar o mundo. E mesmo um ajustar-se a um mundo compartilhado como uma questão de gosto. Mas como Arendt compreendia a relação entre arte e política e qual a relação entre ambas e o mundo comum para ela? E em que isso pode nos interessar?

No texto denominado A crise na cultura: sua importância social e política, que se encontra na obra Entre o Passado e o Futuro, Arendt descreve primordialmente o ponto de conflito entre arte e política que, segundo ela, não pode nem deve ser solucionado e que emerge, fundamentalmente, da recíproca desconfiança que se apresenta entre ambos: os 
artistas - cuja atividade depende de um peculiar isolamento do Homo faber em relação ao público para que possa ser produzida a obra - e os homens de ação na vida pública - cujas atividades relacionadas ao agir e ao falar dependem inteiramente da presença de outrem, o público, para que possam ser realizadas. ${ }^{51}$

Arendt observa, entretanto, que tal conflito não se aplica quando atentamos para os produtos oriundos das artes, visto que os mesmos, diferentemente do momento da sua produção isolada do mundo, precisam agora encontrar um lugar no mundo onde possam aparecer e ser vistos. Tais produtos partilham com os "produtos" políticos, manifestos em atos e palavras, a qualidade de reificados requerer um espaço comum no qual possam tornar-se públicos, isto é realizar seu próprio ser que, tanto na arte como na política, diz respeito à aparição. Em termos gerais, como observa Arendt, "a cultura indica que o domínio público, que é politicamente assegurado por homens de ação, oferece seu espaço de aparição àquelas coisas cuja essência é aparecer e ser belas. Em outras palavras, cultura indica que arte e política, não obstante seus conflitos e tensões se inter-relacionam e até são dependentes" (ARENDT, 1990: 272) ${ }^{52}$.

Realça-se aqui o elemento que liga a arte e a política, e este é o ponto que nos interessa, tendo em vista que ambos, segundo ela, são fenômenos do mundo público. O mundo comum aparece como o elemento de ligação entre os produtos da arte e as ações e os discursos dos homens, pois ambos são fenômenos que requerem ser vistos no palco das aparências que é o próprio mundo, "o que medeia o conflito do artista com o homem de ação é a cultura animi, isto é, uma mente de tal modo educada e culta que se lhe pode confiar o cuidado e a preservação de um mundo de aparências cujo critério é a beleza" (ARENDT, 1990: 273).

No mundo antigo, Péricles falava de um amor ativo à beleza e Cícero imputava tal cultura à educação filosófica, aos amantes do saber que "eram atraídos pelo "espetáculo e observavam atentamente o que se fazia e como era feito". Como diríamos hoje, eram completamente desinteressados e, por essa mesma razão, melhor qualificados para julgar, mas também os mais fascinados pelo espetáculo em si” (ARENDT, 1990: 273). Apoiando-

51 "É esta a verdadeira indisposição do artista, não pela sociedade, porém pela política, e seus escrúpulos e desconfiança da atividade política não são menos legítimos que a desconfiança dos homens de ação contra a mentalidade do Homo faber" (ARENDT, 1990: 272).

${ }^{52}$ A autora chama a nossa atenção para o fato de que a beleza "é a própria manifestação da imperecibilidade. A efêmera grandeza da palavra e do ato pode durar sobre o mundo na medida em que se lhe confere beleza. Sem a beleza, isto é, a radiante glória na qual a imortalidade potencial é manifestada no mundo humano, toda vida humana seria fútil e nenhuma grandeza poderia perdurar" (ARENDT, 1990: 272). 
se na primeira parte da Crítica do Juízo, de Kant, Arendt utilizou a palavra "gosto" para destacar a única atividade na qual, segundo ela, a cultura se expressa como tal (entre os antigos) para indicar "os elementos discriminadores, discernidores e ajuizadores de um amor ativo à beleza" (ARENDT, 1990: 273).

A Crítica do Juízo Estético realizada por Kant contém, segundo Arendt, o maior e mais original aspecto de sua Filosofia Política, "uma analítica do belo, basicamente do ponto de vista do espectador ajuizante, conforme o próprio título indica, e toma como ponto de partida o fenômeno do gosto, entendido como uma conexão ativa com o que é belo" (ARENDT, 1990: 273). Com base na Crítica da Razão Prática de Kant, observa que a faculdade do juízo implica uma atividade mais política do que meramente teórica, visto que:

a capacidade para julgar é uma faculdade especificamente política, exatamente no sentido denotado por Kant, a saber, a faculdade de ver as coisas não apenas do próprio ponto de vista, mas na perspectiva de todos aqueles que porventura estejam presentes; que o homem enquanto ser político na medida em que lhe permite se orientar em um domínio público, no mundo comum: a compreensão disso é virtualmente tão antiga como a experiência política articulada. Os gregos davam a essa faculdade o nome de phrónesis, ou discernimento, e consideravam-na a principal virtude ou excelência do político, em distinção da sabedoria do filósofo. A diferença entre esse discernimento que julga e o pensamento especulativo está em que o primeiro se arraiga naquilo que costumamos chamar de senso comum, o qual o último constantemente transcende (ARENDT, 1990: 275).

O senso comum desvenda a natureza do mundo comum, permite-nos ajustar-se a um mundo "não-subjetivo" (introspectivo) e sim "objetivo" (compartilhado) que possuímos em comum e compartilhamos uns com os outros. E o julgamento é desta maneira uma atividade - talvez a mais importante - em que ocorre esse "compartilhar-omundo". O que Arendt ressalta como sendo inédito nos trabalhos de Kant sobre o juízo é precisamente o exame que ele faz do fenômeno do gosto que, em linhas gerais, apela ao senso comum e opõe-se aos "sentimentos íntimos". Como observa a autora:

Em juízos estéticos, tanto quanto em juízos políticos, toma-se uma decisão, e conquanto esta seja sempre determinada por certa subjetividade, também decorre, pelo mero fato de cada pessoa ocupar um lugar seu, do qual observa e julga o mundo, de o mundo mesmo ser um dado objetivo, algo de comum a todos os seus habitantes. A atividade do gosto decide como esse mundo, independentemente de sua utilidade e dos 
interesses vitais que tenhamos nele, deverá parecer e soar o que os homens verão e ouvirão nele. O gosto julga o mundo em sua aparência e temporalidade; seu interesse pelo mundo é puramente "desinteressado", o que significa que nem os interesses vitais do indivíduo, nem os interesses morais do eu se acham aqui implicados. Para os juízos do gosto, o mundo é objeto primário, e não o homem, nem a vida do homem, nem seu eu (ARENDT, 1990: 276-7).

Como vimos na polis a persuasão regulava as relações entre os cidadãos, excluindo a violência física. A questão é que os juízos do gosto, assim como as opiniões políticas, são persuasivos, correspondendo ao que os gregos denominavam péithein ${ }^{53}$. Em meio a tais traços cultura e política pertencem à mesma categoria, pois o que está em jogo, como observa Arendt, são o julgamento e a decisão, "a judiciosa troca de opiniões sobre a esfera da vida pública e do mundo comum e a decisão quanto ao modo de ação a adotar nele além do modo como deverá parecer doravante e que espécie de coisas nele hão de surgir” (ARENDT, 1990: 277). Considerada a principal atividade cultural, o gosto, neste sentido, é classificado entre as faculdades políticas do homem.

Como observa Arendt, os conceitos de "humanismo" e "cultura" são de origem romana. Apropriando-se de um exemplo romano de Cícero, ilustra que o gosto humaniza o mundo do belo, produz uma "cultura", podendo ser definido como a capacidade política que verdadeiramente humaniza o belo, criando uma cultura. $\mathrm{O}$ humanismo dos romanos aplicava-se a homens livres e, segundo ela, o que Cícero de fato diz: "é que, para o autêntico humanista, nem as verdades do cientista, nem a verdade do filósofo, podem ser absolutas; o humanista, portanto, não é um especialista, exerce uma faculdade de julgamento e de gosto que está além da coerção que nos impõe cada especialidade" (ARENDT, 1990: 280).

Esse humanismo, que se recusa a ser coagido,

é o resultado da cultura animi, de uma atitude que sabe como preservar, admirar e cuidar das coisas do mundo. Ele tem, como tal, a tarefa de

\footnotetext{
53 "O discurso convincente e persuasivo tido por eles como a forma tipicamente política de falarem as pessoas umas às outras" (ARENDT, 1990: 277). Como podemos verificar no dicionário de termos gregos, da mesma raiz terminológica que o termo grego peithó que significa faculdade ou talento para persuadir, eloquência persuasiva, discurso persuasivo, doce e suave persuasão. O verbo peítho significa: persuadir, convencer para que alguém faça de bom grado alguma coisa; seduzir por palavras, súplicas e preces; apaziguar e suavizar por palavras e súplicas; excitar e estimular alguém a aceitar uma opinião ou a fazer alguma coisa; confiar, entregar-se, fiar-se, deixar-se persuadir e convencer, ceder à palavra de alguém, crer na palavra de alguém. Peithó não pretende enganar com seduções falsas e por isso se opõe a apáte, sedução mentirosa. Peithó e apáte são centrais na retórica. Personificada, Peithó é a deusa da boa persuasão e da boa eloquência (CHAUÍ, 1994).
} 
servir de árbitro e mediador entre as atividades puramente políticas e puramente fabris, que se opõem uma às outras de um sem-número de modos. Enquanto humanistas, podemos nos elevar acima desses conflitos entre o político e o artista, do mesmo modo como nos podemos elevar em liberdade acima das especialidades que todos aprendemos e exercemos. Podemos elevar-nos acima da especialização e do filisteísmo de toda natureza na proporção em que aprendamos como exercitar livremente nosso gosto (ARENDT, 1990: 281 grifos nosso).

De qualquer maneira, conclui Arendt: "podemos recordar aquilo que os romanos - o primeiro povo a encarar seriamente a cultura, à nossa maneira - pensavam dever ser uma pessoa culta: alguém que soubesse como escolher sua companhia entre homens, entre coisas e entre pensamentos, tanto no presente como no passado" (1990: 281 grifos nosso).

Lembrando os versos do poeta Rainer Maria Rilke ${ }^{54}$, que insistem tanto em realçar a importância do outro, poeticamente falando, para nos tornarmos algo em si e para si mesmo por causa de outro ser, uma busca de abrigo no mundo às coisas imortais: obras, palavras, feitos, eventos. Um aprender a ver o que se dá no mundo que parece traduzir um ensinamento: a importância do outro na construção da vida comum. Amor ao outro, amor ao mundo, sentido de pertencimento e de cuidado com o humano e comum que transcende a nós mesmos e que por isso mesmo nos revela. Ao que parece ser fundamental reconhecer, neste palco das aparências que nos revela singularmente enquanto ser no mundo, a importância da relação com o outro, através da ação e do discurso, dos feitos e palavras, da pluralidade de um mundo comum assinalado pela diversidade e vivificado pela espontaneidade do novo. Afirmar a preservação e o cuidado com o mundo e com os homens que nele convivem uma tarefa que parece relacionar-se com o educar por amor a ele, um amor que nos humaniza por estar com o outro, e que, em tempos modernos, parece implicar uma postura crítica de resistência à expansiva negação e destruição do mundo que nega e destrói o outro, expande o predomínio do nada e do ninguém e faz crescer o deserto, inclusive, introspectivamente. Caminhemos destacando alguns aspectos da expansão do mundo-deserto que podem representar fatores determinantes no desaparecimento de tais espaços, no âmbito do viver junto, e por extensão no domínio de nossas respectivas singularidades que nos possibilitam ser alguém no mundo.

\footnotetext{
${ }^{54}$ RILKE, Rainer Maria. Cartas a um jovem poeta, tradução de Paulo Rónai, Editora Globo, Rio de Janeiro, 1995.
} 


\section{A EXPANSÃO DO MUNDO DESERTO}

"Na introspecção só está envolvido aquilo que a própria mente produziu; ninguém interfere, a não ser o produtor do produto; o homem vê-se diante de nada e de ninguém a não ser de si mesmo."

Hannah Arendt

Nada, palavra que nos remete ao que não existe, ao que é deserto. Segundo nossos dicionários significa, sinteticamente, coisa nenhuma, que não tem nenhum valor, coisa alguma. Em nossos tempos modernos - e Chaplin que nos diga com suas imagens mudas e em preto e branco, que ainda nos dizem tanto sobre o assunto, sem dizer uma única palavra, muitas e repetidas vezes - caminhamos de nenhum lugar para chegar a lugar nenhum. E a sós. Sem sequer sermos vistos. E tampouco sem conseguimos ver alguém.

Como nas cenas de Chaplin nas quais ninguém consegue enxergar Carlitos, ninguém vê ninguém, ninguém se importa ou tem importância para ninguém. O outro se torna uma miragem para nós, e nós para eles, e avistamos tão somente um imenso mundo deserto a crescer, sem perspectivas de mudança, com pessoas sobrevivendo isoladas e sem confiança umas nas outras, introspectivas, sem um lar ou qualquer ambiente compartilhado ao qual pertençam numa dimensão de profundidade. E que também pode ser traduzido em escombros de destruição de coisas e pessoas, bem como de experiências e significações que são comuns a todos e de suas lembranças, recordações, num quadro que configura o estado de meros viventes mergulhados na mais completa solidão (loneliness), sem esperanças e desamparadas umas das outras.

No texto Introdução na Política Arendt aborda questões sobre o mundo comum e a política, tentando compreender se esta ainda tem algum sentido diante de todo cenário de horror que se expande sobre o mundo moderno, especialmente no século $\mathrm{XX}$, de processos 
devastadores (descomedidos) desencadeados que ocorrem perante os seus olhos, corroborando a moderna perda da autoridade, e que julga e condena como "catástrofes monstruosas que podem transformar o mundo num deserto e o planeta em matéria sem vida" (ARENDT, 2008: 255), e que por isso ameaçam a humanidade inteira até os nossos dias.

Como sabemos a primeira metade do século XX foi marcada por intensas crises políticas, dentre outras coisas, por duas grandes guerras mundiais, pela ascensão de regimes totalitários em diversas partes do planeta, tais como o nazismo na Alemanha e o stalinismo na antiga União Soviética, e pela invenção da bomba atômica empregada para destruir cidades e pessoas. Acontecimentos que influenciaram sobremaneira o pensamento político-filosófico contemporâneo e que, segundo Arendt, podem ser vistos inclusive em termos de um colapso da moralidade, onde a tradição do pensamento moral fora rompida e não mais podia ser restaurada.

Como observa Jerome Kohn na introdução da obra Responsabilidade e Julgamento:

\begin{abstract}
Na sua terra natal, Arendt verificou aquilo que ela e muitos outros tinham dado como certo - uma estrutura moral segura e aparentemente sólida entrara em colapso sob o domínio nazista, invertendo no exemplo mais extremo o mandamento "Não matarás" para "Matarás"; e então, depois do fim da Segunda Guerra Mundial, ela observou outra inversão em que a estrutura anterior foi reinvocada. Mas, nesse caso, que grau poderia ter de solidez e segurança? (ARENDT, 2004: 17-8).
\end{abstract}

Destaca-se aqui evidentemente a que ponto chegou a moderna negação do mundo e a nossa perda da autoridade, deflagrando algumas dimensões das atuais crises que não se restringem ao campo da moralidade e da vida política, mas que abarcam também a própria esfera da educação. Arendt que viveu e sofreu as amarguras deste violento período histórico, especialmente, a ascensão do nazismo na Alemanha, a segunda grande guerra mundial entre 1939 e 1945 e o que dela decorreu, tem diante de si um espetáculo de horror que assola o mundo e que parece traduzir um cenário pleno de destruição e de desumanização. A destruição do mundo parece representar um fenômeno de destruição dos 
homens e vice-versa e a ascensão do nazismo na Alemanha de Hitler na década de 30, a arquitetura da destruição do mundo e dos homens que nele convivem ${ }^{55}$.

Lendo alguns de seus textos, percebemos que Arendt reflete sobre esse ambiente árido no qual está inserida, propondo-se a dizer algo ao mundo, aquilo que pensa sobre o que está vendo, vivendo e condenando, dentre outras coisas, os movimentos totalitários, a expansão do nazismo com sua ideologia e terror, a destruição do mundo humano. Quantas vezes e em quantos lugares, pessoas ficaram completamente desarraigadas, deslocadas, isoladas, sem um lar privado, sem um lar comum, sem direitos, sem proteção, sem nada nem ninguém, num ambiente inóspito e desértico.

Os escritos de Arendt não apenas sobre política, mas também sobre moralidade e educação inspiram-nos a trilhar caminhos de resistência, e até mesmo de transformação, em face de todo esse cenário de horrores e crises que assolaram o mundo moderno solapando toda e qualquer forma de autoridade tradicionalmente reconhecida entre nós. $\mathrm{E}$ isso parece estar ligado à nossa atitude face ao âmbito de nosso passado e em especial ao fato de que não temos assumido neste sentido as nossas responsabilidades pelo mundo. Forçoso nos faz compreendermos tal cenário e o que ele pode nos representar, e Arendt nos sugere que busquemos algumas pérolas em nosso passado, como exemplos, que possam de alguma maneira nos auxiliar nessa tarefa em nosso presente momento que é crítico, repleto de problemas como os que se referem à nossa moderna perda da autoridade em todos os âmbitos.

O sintoma mais significativo de nossa atual crise no que se refere à autoridade, segundo Arendt,

a indicar sua profundeza e seriedade, é ter ela se espalhado em áreas prépolíticas tais como a criação dos filhos e a educação, onde a autoridade no sentido mais lato sempre fora aceita como uma necessidade natural, requerida obviamente tanto por necessidades naturais, o desamparo da criança, como por necessidade política, a continuidade de uma civilização estabelecida que somente pode ser garantida se os que são recémchegados por nascimento forem guiados através de um mundo preestabelecido no qual nasceram como estrangeiros (2007: 128).

${ }_{55}$ O documentário de Peter Cohen, produzido na Suécia em 1992, cujo título é justamente Arquitetura da Destruição, é um exemplo que ilustra isso. 
Tais observações, a partir destes problemas no presente, apontam o quadro crítico no qual mergulhamos (em termos de crise), e de certa forma chamam a atenção para a importância de uma busca pela compreensão de tal quadro a começar pela questão acerca do que a autoridade realmente teria sido e que, como observa Arendt, tanto pratica como teoricamente, não estamos mais em posição de saber o que ela realmente foi, o que nos obriga inevitavelmente a pensarmos e, inclusive, tentarmos pescar pérolas, fragmentos de nosso passado que envolve, dentre outras coisas, o conceito de autoridade oriundo entre os antigos e perdido entre nós.

Mais uma vez, Arendt nos auxilia nessa tarefa ao buscar reconsiderar o que a autoridade teria sido, historicamente falando, inclusive em termos de se pensar acerca das fontes de sua força e significação tradicionalmente reconhecidas. Neste sentido, teríamos perdido o fio que nos guiava "com segurança através dos vastos domínios do passado; esse fio, porém, foi também a cadeia que aguilhou cada sucessiva geração a um aspecto predeterminado do passado" (ARENDT, 2007: 130). Toda a dimensão do nosso passado foi colocada em risco e com isso também nos colocamos na condição de estar ameaçado de esquecimento o que "significaria que, humanamente falando, nos teríamos privado de uma dimensão, a dimensão de profundidade na existência humana. Pois memória e profundidade são o mesmo, ou antes, a profundidade não pode ser alcançada pelo homem a não ser através da recordação" (ARENDT, 2007: 131).

Arendt ressalta que, com tal perda da autoridade em tempos modernos, a dúvida geral invade o domínio público, e chama a atenção para o fato de que cresce o deserto onde não há pluralidade humana, o outro não tem importância para nós na construção de um viver comum, nosso passado não é lembrado e se duvida de tudo, inclusive, de todo e qualquer tipo de autoridade a fazer sentido. Enfim, onde solitariamente predomina uma fuga do nada que nos leva na direção do nada produzindo o próprio nada, imperando a violência e o terror que nos distancia cada vez mais intensamente de qualquer tipo de autoridade ou de responsabilidade pelo mundo, que nos emudece, ignora, descarta.

Um mundo deserto de coisas, pessoas, possibilidades, como numa cidade destruída, violentada e inviabilizada para um viver comum e para a possibilidade de se acolher e inserir o novo no mundo. E que por isso é ameaçada de esquecimento. E é certo que isso diz respeito ao mundo no que tange à sua permanência e durabilidade, ou não, assim como a nós mesmos enquanto pessoas, isto é, enquanto alguém que existe num mundo plural que 
nos precede e que permanecerá após a nossa breve existência. Noutras palavras, a perda da autoridade equivale à perda do fundamento do mundo. Atrevo-me a dizer que, também, equivale à perda do fundamento de nós mesmos. E a questão que fica, ou que passa, é o quanto isso nos afeta?

O quanto isso nos afeta enquanto personalidade, sujeito moral, no sentido arendtiano, e mesmo político, inclusive em termos de se levar em conta o quanto pode nos ser importante simbolicamente pensar e debater os nossos direitos humanos, especialmente, como formação humana para um viver comum, ameaçado de desaparecer em nossos tempos modernos juntamente com todo e qualquer sentido de autoridade que possa ser reconhecido entre nós, seja o mais lato ou o mais específico. Como pensar, debater e realizá-los em tais circunstâncias, com tais propósitos? Expande-se o silêncio e, introspectivamente, sumimos em nós mesmos, não mais nos encontrando, e não vendo possibilidades de enxergar alguma coisa ou alguém que nos acompanhe a não ser nada e ninguém, tudo parece desaparecer, não há diálogos, ações, reflexões, possibilidades, esperanças, sentidos.

Constitui-se um cenário desértico, carregado de crises (moralidade, política, educação), a ser compreendido por nós sob pena de se expandir ainda mais intensamente no mundo e nas pessoas que nele vivem. Não há mundo comum, não há pessoas. Produz-se o nada e o ninguém predominando homogeneamente meros seres humanos supérfluos e descartáveis que tão somente buscam a sobrevivência da espécie (também ameaçada), deixando de lado suas respectivas singularidades que as constituem enquanto pessoas, sujeitos morais, capazes de pensar e lembrar, isto é "deitar raízes", onde cada tem possibilidade de tomar seu lugar no mundo como alguém que pode ser capaz de falar e agir em conjunto na vida pública e política com vistas a cuidar do mundo em termos de permanência e durabilidade. E por amor a ele.

O sinal mais seguro dessa crise é o desaparecimento do senso comum, a destruição de algo que nos é comum a todos nós e que nos auxilia a nos movermos no mundo. Como observa Arendt, "em toda crise, é destruída uma parte do mundo, alguma coisa comum a todos nós. A falência do bom senso aponta, como uma vara mágica, o lugar em que ocorreu esse desmoronamento" (2007: 227). E tal crise no mundo moderno que abrange o âmbito da moralidade, da política e da própria educação (na medida em que a crise nesta reflete a crise no mundo) deve muito de seu crescimento ao totalitarismo que 
instrumentalizou institucionalmente a burocracia (governo de ninguém) e, com ela, a ideologia e o terror totalitário, não apenas em face do nada, mas também do ninguém, nas palavras de Arendt, um mero ser humano que se recusa a ser uma pessoa, que deixou de se constituir como alguém na medida em que "se recusa a pensar por si mesmo no que está fazendo e que, em retrospectiva, também se recusa a pensar sobre o que faz, isto é, a voltar e lembrar o que fez" (ARENDT, 2004: 177).

Numa sociedade de massas que descarta o humano, extingue o comum e almeja manter as pessoas como meros viventes homogeneizados, silenciados e incapacitados não apenas para agir, mas também para pensar e lembrar, abandonados a mais completa solidão, na qual não se tem sequer a companhia de si mesmo enquanto pessoa, tampouco a dos outros (como amigos), despojados da capacidade de pensar e de submeter os acontecimentos a julgamento (decisão em respeito a si mesmo), onde a responsabilidade pelo mundo não apenas deixa de ser assumida, mas é absolutamente rejeitada (e com ela a autoridade), na medida em que não mais nos indagamos com que outro queremos viver juntos. Aliás, tal indagação não apenas deixa de ser realizada como passa a não fazer ou ter mais nenhum sentido.

A sociedade de massas caracteriza-se pela introdução de uma esfera social entre o mundo público e o privado, onde um é transformado no outro e vice-versa (ambos são misturados), apresentando as melhores condições para o domínio totalitário que se contrapõe a qualquer tipo de autoridade, por ser violento e desprezar o passado, e que tem possibilidade de por intermédio da ideologia e do terror deixar pessoas abandonadas, em solidão (loneliness), sem possuir um lar no mundo, uma comunidade à qual pertençam, ou mesmo sem qualquer tipo de proteção do governo, a ponto de não se ter direito a ter direitos, não ter nada nem mesmo uma informação correta tampouco a própria vida para viver.

Pessoas alienadas, desarraigadas e superfluídas graças à interferência totalitária que leva às últimas consequências alguns fatores característicos dos principais eventos ocorridos na Era Moderna que, segundo Arendt, teriam nos levado a tal crise nesse processo de desertificação do mundo humano, dentre os quais, a alienação da Terra e do mundo, a dúvida cartesiana e a perda do senso comum. No totalitarismo cristalizam-se de forma radical vários traços que se desenvolveram a partir da vida moderna e que negam o mundo, fazendo dos homens seres desamparados, sós e sem lar, num mundo em crise que 
com a ajuda do terror e da ideologia totalitária promove a homogeneidade e a alienação (do lar, da família, do direito, da comunidade, do mundo), acabando por dar as costas para o mundo comum e para as pessoas que nele convivem para fazer prevalecer a burocracia e a violência sem par, expandindo cada vez mais intensamente o processo de desertificação de coisas e pessoas com a sobrepujança do nada e do ninguém sobre alguma coisa e alguém.

Um ambiente árido e sem fundação, que certamente não apresenta nenhum traço que se aproxime daquilo que foi o conceito de autoridade em suas origens, e que, segundo Arendt, insiste em demonstrar violentamente e de maneira ideologicamente totalitária que na vida pública e política a autoridade e suas interligações, tais como a experiência da fundação ou mesmo o sentido de responsabilidade que lhe é correspondente em termos de uma comunidade política, passam a não representar mais nada, tendo em vista que a violência e o terror exercidos pelos países totalitários nada tem a ver com autoridade e sequer com qualquer tipo de responsabilidade pelo mundo comum.

É como se a expansão de tais processos de desertificação do mundo representasse simbolicamente a própria ausência de responsabilidade para com a durabilidade e a permanência do mundo em tempos modernos. Mas qual é o sentido do conceito de autoridade que se perdeu, ao qual nos referimos, e por que ele se interliga à experiência da fundação outrora ocorrida? Referimo-nos a um conceito que, segundo Arendt, teria surgido no passado (mais especificamente com a fundação de Roma) e desaparecido do mundo moderno pelo declínio constante do papel da tradição na vida pública. Desaparece o caráter sagrado - supra-humano - do passado. No caso de Roma, da fundação, 'dos maiores'.

A metáfora do deserto delineada por Arendt representa muito bem esse quadro, apontando-nos uma crise de autoridade que em seus contornos, como ela mesma observa, é política em sua origem e natureza. E que vai respingar na própria esfera educacional, tornando-se um problema a ser pensado por quem lida com educação, isto é, de uma forma ou de outra todos e cada um de nós. As formas totalitárias de governo estão aí a mostrar a gravidade de nossa crise que é política, moral, educacional e, em todos os âmbitos, também uma crise de autoridade.

Essa perda da autoridade no mundo moderno à qual Arendt se refere diz respeito a uma forma bastante específica de autoridade que fora válida em todo o mundo ocidental durante muito tempo e que remonta à experiência política romana de fundação. Referimonos ao conceito de autoridade nos termos que nos são apresentados pela autora ressaltando 
sê-lo, tanto no que se refere à palavra quanto no que tange ao conceito, de origem romana ao derivar-se a palavra auctoritas (autoridade) do verbo latino augere (aumentar).

Aqui, vale lembrar que, para os romanos, o crescimento dirigia-se no sentido do passado e que, em contraposição ao poder, a autoridade tinha suas raízes justamente nesse passado que cresce. E, como observa Arendt, aquilo que a autoridade, ou os de posse dela, constantemente aumentavam que era a fundação. Neste sentido, toda autoridade derivava da fundação e um fundador poderia ser considerado um "aumentador", por exemplo, da cidade na medida em que estivesse de posse da autoridade para aumentar a fundação da comunidade política à qual pertencia trazendo todo o peso de seu passado e assim fazendoa crescer e perdurar. Ao distinguir-se da persuasão e da violência, a autoridade era fundada na confiança naqueles que encarnavam o passado (os maiores), havendo uma espécie de hierarquia que era aceita como legítima, pois vinculada à fundação, ou seja, ao caráter vinculatório que o passado estabelecia com o presente.

A dominação totalitária, ao contrário disso, qualifica-se especialmente pelo seu mais completo menosprezo e desrespeito à autoridade e à responsabilidade pelo mundo, inclusive para com a durabilidade e a permanência da comunidade política e das pessoas que nela convivem. Em tal ambientação infecunda e desarraigada não podemos nos sentir em casa no mundo, e vivemos numa esfera social em que não há autoridade e a responsabilidade é rejeitada tendendo a autoridade a desaparecer, como parece ter desaparecido. Ausente a vida pública e política expande-se o processo de desertificação das pessoas e do mundo. Esse é o panorama.

O papel confiado outrora à tradição e à autoridade, como algo que de certa forma nos transmitia um legado e nos ligava ao nosso passado fazendo-o crescer, fica completamente comprometido em tal cenário desértico, especialmente no que tange à permanência de uma comunidade política, isto é, um lugar onde podemos nos sentir em casa no mundo. E com esse desaparecimento da autoridade em tempos modernos mergulhamos numa crise sem tamanhos que nos deixa desamparados num solo arenoso no qual não conseguimos firmar apoio e sequer vislumbrar alguém (uma companhia) com quem seguir. Um problema que nos obriga a pensar sobre o assunto.

O deserto se expande distanciando-nos de nossas companhias no mundo, levandonos a uma sensação de abandono e impotência, niilismo em face do mundo e de nós mesmos. Aquilo que Nietzsche já prenunciava, com o seu niilismo e criticidade no século 
anterior na Europa, e que irá assolar o mundo moderno e toda a humanidade em nossos tempos: o deserto cresce, outrora com o nada e, agora, também com o ninguém. Aspectos marcantes dos tempos modernos que fazem expandir a desesperança e a ausência de possibilidades não apenas de um viver compartilhado entre as pessoas, mas também de um viver consigo mesmo enquanto personalidade moral que mesmo estando só, nas palavras de Arendt, está junto de alguém (eu mesma), um ser pensante, nesse diálogo silencioso de mim comigo mesmo (dois-em-um).

A expansão do deserto faz acender a solidão (loneliness) caracterizando a imagem de cidades que já não têm mais vida, na qual o nada tomou conta e não sobra mais ninguém (enquanto pessoa), ambientes inóspitos, lugares na situação do mais completo abandono, sem algo para dar e receber apoio, isto é, um mundo comum desmantelado, sendo esquecido. E de pessoas introspectivas. Este é o quadro de nossa modernidade que nos coloca numa crise sem tamanho, e que tanto nos leva a tentar compreender o que está aí posto, ou talvez, imposto, de maneira violenta e arbitrária, com seu ponto de destaque sendo alcançado na ideologia e no terror totalitário, uma espécie de síntese que traduz o que há de pior em nossos tempos e em nossa condição humana. Obriga-nos a pensar com vistas a novas possibilidades, novos caminhos, nem que seja por entre escombros de destruição de lugares, coisas e pessoas. Nietzsche parece não ver possibilidades de mudança nesse cenário desértico, enquanto Arendt - embora reconheça haver grandes possibilidades de não serem realizadas - parece as vê-las com esperança no "milagre da ação", daí ser possível, mas tão somente pela inserção do novo no mundo.

Como todo novo início (initium: que é o homem enquanto ser que age), o milagre da ação pode irromper no mundo, diz Arendt, como uma "improbabilidade infinita" capaz de interromper o automatismo de nossas condições desérticas com algo inesperado e imprevisível. Por exemplo, um caminhar que resiste a se adaptar a tais condições e que insiste em buscar realizar transformações por atos e palavras desempenhadas no domínio comum. Ou senão, parar e pensar e, simplesmente, recusar-se a fazer alguma coisa para não entrar em contradição consigo mesmo.

Dilemas humanos em tempos modernos que ainda permanecem conosco no presente realçando os planos da solidão e da impotência humana em face de tais atrocidades como o mais provável e que se sobrepuja a qualquer tipo de conduta moral ou mesmo de atuação política de resistência e de negação a tudo isso. E o ponto central 
justamente é esse: por que mesmo em tal ambientação árida e hostil, pessoas, como sujeitos morais e políticos, resistiram a tais processos de desertificação? Por que alguns disseram não à expansão do mundo deserto? Por que alguns resistem à negação do mundo servindo-nos como exemplos?

Provavelmente por não concordar com tudo isso e por ter a coragem de assim o fazê-lo (como Sócrates também o fez, noutro contexto, perante o tribunal ateniense). Assim como Jesus de Nazaré, noutro. E certamente para não estar em desacordo consigo mesmo e poder seguir caminhando acompanhado por alguém. Segundo Arendt, são homens que realizam tais milagres, "homens que por terem recebido o dúplice dom da liberdade e da ação, podem estabelecer uma realidade que lhes pertence de direito" (2007: 220). E assim o fazem justamente em momentos que são críticos.

Isso nos remete de alguma forma às cenas finais de um filme denominado $O$ Pianista, que retrata um contexto histórico que vale a pena ser levado em conta, entre nós, quando o assunto é violência, destruição, quando tudo parece perdido e aceitar isso representa estar em desacordo consigo mesmo. Inspirado num livro autobiográfico de mesmo nome, escrito por um músico polonês, o filme retrata uma cidade da Polônia, Varsóvia, completamente destruída pelos nazistas durante a segunda guerra mundial, na qual o pianista sobrevivente da guerra e da perseguição aos judeus, estando só, caminha por entre os escombros de destruição das coisas e pessoas da cidade em busca de alguma coisa ou alguém.

Tocado pela música e especialmente pelo piano, sua companhia, inclusive na sublimação da dor, o personagem não desiste de viver e de buscar abrigo no mundo, mesmo em face de tantos horrores, destruições, barbáries e motivos para desistir, sumir. Após toda destruição e violência totalitária nazista, o pianista segue por entre escombros para dentro da cidade, completamente destruída, em busca de alguém e de alguma coisa que tenha sobrado, para lá, possivelmente, conviver. Essa é a sua escolha, trilhar por entre escombros de coisas e de pessoas em busca de um mundo, alguma coisa, alguém, um lugar para viver junto às pessoas e lá pertencer à humanidade numa dimensão de profundidade existencial.

As imagens do filme sobre a história do pianista, assim como as cenas de Chaplin representadas pela figura de Carlitos, são exemplos que nos incitam a pensar sobre essa amplificação dos processos de desertificação não apenas em nossas cidades destruídas, mas 
também em nós mesmos ao rumarmos em amplidão para campos de solidão (loneliness) e impotência (incapacidade de agir) em tempos modernos. E também, em contraposição a isso, a exemplos, caminhos de resistência, escolha de nossas companhias. Levam-nos inevitavelmente ao encontro de Arendt (uma companhia no mundo) e de sua metáfora do deserto que tanto insistimos em realçar como algo a ser pensado, compreendido, transformado.

E mesmo à opção por se caminhar, ou não, introspectivamente num mundo em que predomina o nada e o ninguém, onde não há esperanças, diálogos, pluralidade humana tampouco a possibilidade do novo que pode, quem sabe, com a contribuição da educação, transformar por atos e palavras realizadas, desempenhadas num ambiente comum, nada em alguma coisa, ninguém em alguém, ausência de lar em morada comum, na qual temos possibilidade de pertencer de maneira humana e singular, de modo a estarmos junto de alguém que nos acompanha entre coisas, pessoas, pensamentos, lembranças. Arendt nos oferece pistas neste sentido, algumas no âmbito daquilo que podemos chamar de moralidade, outras no da vida política e, "despretensiosamente" (em razão da quantidade de coisas escritas por ela sobre o assunto), consideráveis na esfera da educação, especialmente no que tange à sua importância e ao seu sentido como formação para o viver comum, onde a responsabilidade assumida pelo mundo e autoridade assentada sobre ela tornam-se fatores fundamentais. ${ }^{56}$

Caminhamos num ambiente no qual ninguém merece a confiança de ninguém e onde não se pode contar com coisa alguma. Nosso encontro com nada e, também, com ninguém, parece descrever simbolicamente alguns dos principais traços que marcam os tempos modernos de desertificação em que seres humanos, muitas vezes, parecem renunciar voluntariamente a todas as suas qualidades pessoais, enquanto sujeitos morais, capazes de pensar e julgar e, neste sentido, como observa Arendt, de estar junto de alguém (que os acompanha).

\footnotetext{
${ }^{56}$ Nas últimas décadas o interesse pelo estudo de Hannah Arendt nas esferas educacionais, especialmente nas universidades, mas não somente, tem sido bastante significativo e digno de ser pensado. José Sérgio Carvalho chama a nossa atenção para o fato de que "o crescente interesse que educadores, pesquisadores e intelectuais ligados à educação têm manifestado em relação à obra de Hannah Arendt chega a ser surpreendente. Isso porque, diferentemente do que ocorreu com pensadores como Dewey, Rousseau ou Platão, a formação educacional não é tema recorrente ou central nos escritos de Arendt". Prefácio da obra Educação em Hannah Arendt; entre o mundo deserto e o amor ao mundo de Vanessa Sievers de Almeida. São Paulo: Cortez, 2011, página 9.
} 
Realça também algumas das experiências humanas mais marcantes dos últimos séculos, e em especial do século XX, que por alguns aspectos se estende até os dias de hoje, permanecendo conosco, e que são dignas de serem pensadas e debatidas entre nós, a moderna perda de um solo, de uma tradição fundada em algo como, por exemplo, um lugar comum no qual compartilharmos com profundidade experiências e significações, o viver juntos em amizade, confiança, respeito mútuo e pertencimento (lembrando-se daquilo que falávamos acerca de exemplos, tais como em Aristóteles o sentido de uma autossuficiência de tipo comunal).

Noutros termos, a moderna capacidade humana de negar o mundo, de colocar em risco, ou mesmo de destruir, toda forma de vida humana em comum, e a nossa insolúvel crise na modernidade na interface com o nada e com o ninguém, que não fala nem age na vida pública e que se recusa a ser uma pessoa (um sujeito moral) que se constitui como alguém, no sentido arendtiano, um ser pensante que decide com respeito a si mesmo e que pode ser capaz de viver consigo mesmo e decidir com respeito a si mesmo, sem restringirse a obedecer a ordens de outrem e, fundamentalmente, sem estar em desacordo consigo mesmo, julgando ser melhor sofrer o mal do que fazê-lo ${ }^{57}$.

Arendt recorre ao exemplo de Sócrates, que acreditava que os homens são seres pensantes (são dois-em-um), e não abria mão dessa faculdade, especialmente no que tange à sua conduta em face de seu julgamento perante o tribunal ateniense, como princípio fundador do pensamento moral ocidental, para realçar que alguém se constitui como uma pessoa (personalidade moral), distinta de um mero ser humano, pelo pleno exercício de sua capacidade reflexiva enquanto ser pensante que "deita raízes" e que entende que tem de viver acompanhado de alguém, isto é, outro-eu mesmo, com o qual não pode estar em desavença e desarmonia. Arendt chama a nossa atenção para o fato de que a moralidade socrática só nos é politicamente relevante em tempos de crise quando o eu (como critério fundamental da conduta moral) é uma espécie de medida de emergência em termos políticos ao menos para dizer: "pare e pense" (2004: 170).

Inspirada nisso Arendt observa que,

os maiores malfeitores são aqueles que não se lembram porque nunca pensaram na questão, e, sem lembrança, nada consegue detê-los. Para os seres humanos, pensar no passado significa mover-se na dimensão da

\footnotetext{
${ }^{57}$ Os escritos de Arendt relatando o que aparecia durante o julgamento de Eichmann dão amostra disso: um mero ser humano incapaz de pensar, que nunca pensou no que estava fazendo.
} 
profundidade, criando raízes e assim estabilizando-se, para não serrem varridos pelo que possa ocorrer - o Zeitgeist, a História ou a simples tentação. O maior mal não é radical, não possui raízes e, por não ter raízes, não tem limitações, pode chegar a extremos impensáveis e dominar o mundo todo (2004: 159-160).

Os aspectos que aqui se apresentam anunciam que estamos a tratar daquilo que Arendt metaforicamente delineou representar a moderna expansão dos processos de desertificação não apenas no que se refere ao mundo, mas a nós mesmos, enquanto pessoas que se constituem como alguém capaz de pensar, lembrar e julgar por si mesma. Temos deixado de lado a nossa capacidade reflexiva e, juntamente com ela, a nossa qualidade de ser uma pessoa que não apenas pensa e lembra, mas também que julga. Para Arendt, o pensamento é uma atividade e pode ser traduzido em produtos, coisas do pensamento, tais como a música, os poemas e certamente juízos. Dentre outras coisas, subjaz a moralidade, pois o critério de ter de viver comigo mesmo é um princípio puramente moral, que diz respeito ao indivíduo na sua singularidade, ao ser capaz de dialogar silenciosamente com esse parceiro que carrega consigo (outro-eu mesmo). Neste sentido, não apenas podemos, como é fundamental que reflitamos, por exemplo, acerca da questão "o que devo fazer?" e mesmo de escolher em que mundo viver e com quem.

O que nos levaria em ultima instância a escolher, e decidir com respeito a nós mesmos, ou não, por quais caminhos trilhar: a sós, isto é, silenciados e sem companhia não apenas em respeito aos outros, mas em relação a si mesmo, impotentes, céticos e introspectivos num ambiente inóspito a nós mesmos e ao mundo comum, ou, por outro lado, junto de alguém que nos acompanha em nossa trajetória reflexiva, estando só (solitude), onde sou dois-em-um num dialogo silencioso de mim comigo mesmo, e mesmo entre amigos no viver comum em que temos possibilidade de dialogar e agir em conjunto. Qual seria o nosso juízo sobre isso? E em razão disso, onde viver e com quem?

Em Algumas questões de filosofia moral, Arendt estabelece algumas distinções entre os modos de estar sozinho, dentre os quais, o "estar só" (solitude), a solidão (loneliness) e o isolamento (isolation), chamando a atenção para o fato de que: 
respeito. Passarei a chamar o modo de existência presente nesse diálogo silencioso de mim comigo mesma de estar só (solitude). Assim, o estar só é mais do que os outros modos de estar sozinha, é diferente desses outros modos, particularmente e principalmente da solidão (loneliness) e do isolamento (2004: 163).

Aqui, no "estar só", apesar de estar sozinho, não me encontro na mais completa solidão (loneliness) - onde perdemos nossa capacidade comum de pensamento e lembrança (e com elas de julgamento), característica dos seres humanos desarraigados e superfluidos na sociedade de massa, na qual o indivíduo não tem nenhuma companhia, nem dos outros nem dele mesmo, pois o estar junto de alguém que é eu-mesmo e que me constitui singularmente como personalidade, sujeito moral, nesse diálogo silencioso de mim comigo mesmo, possibilita-me pensar e decidir em respeito a mim mesmo sobre o que fazer, tendo alguém como companhia, no caso: eu mesmo (alguém que me acompanha e que me auxilia na tomada de minhas decisões) ${ }^{58}$.

Segundo Arendt, essa dicotomia interior é própria do estar só (solitude) e de sua atividade correspondente que é o pensar (dialogo silencioso de mim comigo mesmo). É um modo peculiar de estar só no qual alguém me acompanha (eu mesmo), que se distingue da solidão (loneliness) e do isolamento (isolation) que "não conhecem esse tipo de cisma, essa dicotomia interior em que posso fazer perguntas a mim mesma e receber respostas" (2004: 163). E neste sentido, ao realizar minhas escolhas, buscar não estar em desacordo comigo mesmo em respeito a mim mesmo e ao que devo, ou não, fazer. Como observa Arendt, a preocupação com o eu como padrão fundamental da conduta moral só existe nesse estar só (solitude) e na sua atividade correspondente que é o pensar no qual sou dois-em-um ao realizar um dialogo silencioso de mim comigo mesmo. E sua validade demonstrável, como observa Arendt, encontra-se:

"na fórmula geral "É melhor sofrer o mal do que fazer o mal", que se baseia na intuição de que é melhor estar em desavença com o mundo inteiro do que, sendo Uma Só, estar em desavença comigo mesma. Essa validade só pode ser mantida para o homem na medida em que ele é um ser pensante, que precisa da companhia de si mesmo em vista do processo de pensamento. Nada do que dissemos é válido para a solidão e o isolamento" (2004: 164-5).

\footnotetext{
${ }^{58} \mathrm{Na}$ introdução à edição brasileira da obra Responsabilidade e Julgamento, temos que para Arendt a noção de personalidade "aludiria a uma espécie de atualização permanente de nossa singularidade, por meio do exercício constante da capacidade de pensar, contínua e reiterada a cada nova situação" (2004: 44).
} 
Em tais processos de pensamento, tenho alguém que constantemente me acompanha e que me dá conselhos a respeito de qual caminho devo seguir, eu mesmo, nesse diálogo silencioso de mim comigo mesmo. Daí porque alguns dizerem não e ainda resistirem, para não estar em desacordo consigo mesmo e poder seguir acompanhado por alguém.

Quando falamos de expansão do nada, e mais especialmente do ninguém, estamos a falar, por exemplo, da solidão (loneliness) como algo que diz respeito a meros viventes humanos, sem nenhuma companhia no mundo (nem mesmo a de si), que não se constituem como pessoas, sujeitos morais e que, neste sentido, são distintos do estar só (solitude) que se constitui como alguém que reflete, é capaz de julgar e lembrar (tendo alguma companhia no mundo, inclusive no sentido de uma autoridade). Falamos não apenas do predomínio da solidão (loneliness), mas também da marca da impotência, incapacidade de agir, quando o assunto é a vida pública, mantida e movida por ditos e feitos realizados no âmbito comum, palco de nossas aparições. Em nossos processos de desertificação que se ampliam cada vez mais, solidão e impotência caminham lado a lado, e não se possui nenhuma companhia no mundo, nem mesmo a de si, por isso nada se pensa, lembra, julga.

Ao contrário, na parte final do texto que trata das origens do totalitarismo, Arendt ressalta o quanto tal ambientação desértica é profícua não apenas ao isolamento (isolation), mas especialmente à solidão (loneliness), na medida em que faz perder algo que nos une em torno de significações e experiências que nos são comuns a todos (senso comum). E que necessitamos para sentir, viver e mesmo encontrar um caminho num mundo que nos é compartilhado e pelo qual assumimos responsabilidades não apenas no que diz respeito à realização de escolhas, mas também de juízos e deliberações em face da permanência e da durabilidade, ou não, do mundo comum.

Dentre outras coisas, realçam-se as noções de desarraigamento e superfluidade, quando meros seres humanos deslizam sobre a superfície dos acontecimentos sendo incapazes de mergulhar numa dimensão de profundidade da existência humana, "não ter raízes significa não ter no mundo um lugar reconhecido e garantido pelos outros; ser supérfluo significa não pertencer ao mundo de forma alguma. O desarraigamento pode ser a condição preliminar da superfluidade, tal como o isolamento pode (mas não deve) ser a condição preliminar da solidão" (ARENDT, 2007: 528). O deserto é desarraigamento e 
superfluidade, ambiente inóspito à vida comum. Não ter raízes e "superfluir" é viver e se adaptar às modernas condições do deserto nas quais não penetramos em qualquer dimensão de profundidade, seja ela histórica ou o que o valha, não possuímos um lar comum e vivemos isolados, introspectivos e impotentes, não somos vistos e não vemos ninguém, não temos e não damos importância a nada nem ninguém.

Não nos identificamos com o outro, predomina a homogeneidade e o automatismo numa esfera social em que os âmbitos da vida pública e privada se confundem, fazendo imperar o silêncio e a incapacidade de agir. A solidão numa sociedade de massas e a violência do terror totalitário podem contribuir significativamente para a expansão desse mundo desarraigado e superfluido que representa uma ameaça a toda e qualquer forma de vida humana em comum e, neste sentido, a toda e qualquer forma de autoridade e responsabilidade pelo mundo, tais como as representadas por Arendt, por exemplo, na figura do educador.

O que muitas vezes arremete o ser humano dos nossos tempos com a vontade de sumir, escapar deste mundo que desloca e descarta pessoas em nome de nada e por nada. Ou senão, habituar-se a ele em desarraigamento e superfluidade, como única alternativa possível de sobrevida, num mundo que descarta o próprio homem, deixa-o sem lar, sem comunidade, sem direito a ter direitos, deslocado no e do mundo ou, na melhor das hipóteses, restrito à condição humana de animal laborans, indivíduos isolados, inseridos numa sociedade de massas, governada por ninguém, que trabalham única e exclusivamente para sobreviver, consumir um mundo que ruma a desaparecer, a tornar-se nada ou coisa alguma sem ninguém (um mundo deserto a crescer, agora, na velocidade do consumo e da produção numa sociedade de consumidores que acomoda a todos cada vez mais imediatamente numa única direção: rua de mão única, fluxo vital, sobrevivência da espécie, consumo do mundo).

Questões, dilemas e problemas que assolaram definitivamente o século XX com a eclosão de grandes conflitos mundiais e especialmente com o predomínio de governos totalitários, tirânicos e ditatoriais por todo o nosso planeta, que insistiram violentamente - e em muitos lugares e momentos ainda insistem - em realçar a barbárie, violência, intolerância, desigualdade, desrespeito e violação a direitos humanos os mais elementares, tais como a liberdade de locomoção, de opinião e o próprio direito à vida, dentre tantos outros, mas especialmente, e de maneira mais marcante, o direito a ter direitos, e dentre 
estes o direito a ter um lar, uma comunidade, de pertencer a um domínio político, de ser visto e de ver alguém, e nele opinar, significativamente, e agir, eficazmente.

O governo totalitário e seus protagonistas renunciaram voluntariamente a todas as suas qualidades pessoais enquanto alguém que se constitui como pessoa, tornando-se um ninguém que não reconhece qualquer direito que se lhe apresente como um empecilho à produção ideológica totalitária, promovendo para muitas pessoas inclusive a perda de todo e qualquer tipo de direito como, por exemplo, o de ter um lar no mundo, ou mesmo o direito a ter direitos. Não há melhor exemplo nesse sentido do que a atuação de um burocrata. O que é feito parece não implicar assumir qualquer responsabilidade pelo mundo. Essa foi a regra, e não a exceção, promovida "sem parar e pensar" pelos realizadores da ideologia e do terror totalitário (governo de ninguém), os exemplos são inúmeros, expande-se o processo de desertificação de coisas e pessoas em sociedades de massa, colocando-se em xeque toda e qualquer significação de autoridade, bem como de responsabilidade pelo mundo comum que parece não mais existir nem fazer sentido.

Tarefa que o governo totalitário nazista, por exemplo, cumpriu como ninguém a ponto de construir campos de concentração e de extermínio de pessoas. Prova máxima de tais aberrações. Daí a mais completa perda de um solo - ante tantas atrocidades - que nos oferecesse apoio para seguirmos adiante levando experiências e significações comuns. Chegamos ao limite de uma manifesta negação do mundo, das pessoas, e nela entramos numa crise que nos obriga a pensar ou repensar a nossa atual condição e mesmo escolher com quem seguir, e para onde, em face de tamanho desmantelamento do que nos é comum, que muitas vezes nos assustam, inclusive, ao aparecer no presente com novas roupagens.

Metaforicamente é como se estivéssemos vivendo mergulhados num imenso ambiente inóspito e desértico, sem desistir, em busca de algo e de alguém que nos dê (e para quem possamos dar) abrigo, cuidado e confiança, um mundo comum, distinto daquele e melhor para se viver numa dimensão de pertencimento e profundidade histórica. Usando uma expressão arendtiana sobre tal crise no mundo moderno, refletida na esfera da educação, isso tem nos obrigado a pensar sem corrimãos para tentar dar conta de nosso presente sem fugas, escapismos ou mesmo adaptações, conformismos. Os quais muitas vezes ainda batem a nossa porta no presente, assim como no passado, querendo entrar, ou mesmo entrando em nossas vidas para dizer que não temos outra opção senão nos habituarmos a tal condição. Ou então sumir, pois não há o que fazer tampouco dizer para 
mudar tal situação no mundo e em relação às pessoas que nele convivem, ou melhor, apenas sobrevivem. Não há nada nem ninguém que nos de apoio, não podemos contar com o auxílio de uma tradição que se desmantelou e o que temos é uma herança que nos foi deixada sem testamento. E isso não tem como deixar de nos provocar insistentemente em nossa realidade cotidiana, no mínimo, isso nos obriga a pensar e a tentar buscar um rumo, especialmente quando o assunto é educar por amor e cuidado ao mundo humano e às pessoas que nele convivem.

Muitos foram descartados, deslocados, outros tantos, sumiram, fugiram ou adaptaram-se. No filme que retrata a história do pianista, após todo o processo de destruição de sua cidade e das pessoas que nela morava, ele adentra os escombros e volta, em respeito ao mundo e a si mesmo. Talvez esteja à procura de algo, alguém, que ainda o acompanha. E nós, o que fazemos em nosso contexto no presente? Também sumimos? Também voltamos? Fugimos, ficamos? Adaptamo-nos? O que procuramos? Quais são as nossas escolhas? E o que, afinal, encontramos? Qual lugar? E quem?

E isso nos faz pensar em tais questões em nossos dias, especialmente quando o assunto é educação, são questões que nos levam inevitavelmente a fazer escolhas e trilhar diferentes caminhos. Por exemplo, o que pode representar uma escolha por sumir quando o assunto é ser um professor ou mesmo um pai? Ou então, se a nossa opção fosse seguir definitivamente por uma caminhada introspectiva, que não dialoga com o novo nem com o mundo e que se adapta às condições desérticas, o que aconteceria? Isso traria algum tipo de implicação para nós, para o mundo? Os novos não seriam inseridos no mundo pelos mais velhos e a opção seria pelo crescimento de um mundo desertificado. Abandonar os novos, não inseri-los num mundo que já existia antes da chegada deles. Podemos optar por isso quando o assunto é sermos pais, professores? Entendemos com Arendt não ser essa a melhor opção, a responsabilidade pelo mundo cabe aos mais velhos. Estes não podem sumir.

Uma coisa é certa, refletir sobre o sentido da metáfora do deserto no pensamento político-filosófico de Arendt parece ser importante para compreendermos o próprio significado de tais indagações e mesmo de nossa humana condição. E dos caminhos que elas podem nos sugerir, dentre os quais, por exemplo, a escolha por seguirmos acompanhados, inclusive, por nós mesmos (não estando em desacordo conosco) e, de preferência, entre amigos (philia) para um viver comum. As imagens de Chaplin e as 
escolhas de Carlitos nos levam a isso. O pianista, também. Hannah Arendt e os exemplos que a inspiram, tais como Sócrates e Jesus de Nazaré, certamente.

Em Algumas questões de filosofia moral, lemos que a faculdade de julgar como um exercício de nos colocarmos no lugar do outro alude à escolha das nossas companhias, daqueles com os quais nós desejamos viver, estar juntos e nossas decisões sobre o certo e o errado, segundo Arendt, vão depender de nossa escolha das companhias, "daqueles com quem desejamos passar a nossa vida. Uma vez mais, essa companhia é escolhida ao pensarmos em exemplos, exemplos de pessoas mortas ou vivas, reais ou fictícias, e em exemplos de incidentes passados ou presentes" (2004: 212). Neste sentido, Arendt nos convoca a que não nos recusemos a pensar e julgar, bem como a assumir as nossas responsabilidades pessoal e política pelo mundo, e isso implica a cada um enquanto pessoa (alguém) a responsabilidade de escolher a si mesmo em respeito a si mesmo e a partir disso a tomar um lugar no mundo numa dimensão de pertencimento e profundidade que dialoga com o outro e que assume a responsabilidade por ele.

O que nos instiga a pensarmos sobre que caminhos seguirmos, com quem e para onde, e julgarmos por nós mesmos, explicitando nossas escolhas e elegendo nossas companhias. Por exemplo, mundo comum ou mundo deserto, entre amigos ou isolado, aparecendo ou sumindo, sofrendo ou se conformando? O que pensamos disso e quais são as nossas escolhas a esse respeito? Quais exemplos escolhemos para guiar nossa conduta? Com quem vamos seguir e para onde vamos neste sentido? Esticando esteiras? Deitando raízes? Não se contradizendo a si mesmo? Julgando melhor sofrer o mal a cometê-lo? Querendo encontrar alguém, ou não? Pensando? Agindo? Falando?

Nas primeiras linhas do Epílogo da obra A Promessa da Política, a ideia de expansão de um mundo-deserto representa o crescimento do que Arendt chamou de “ausência de mundo" e está diretamente relacionada a tais aspectos e eventos, característicos da modernidade, bem como às origens e à ascensão do totalitarismo que marcam a época na qual a autora viveu especialmente na Alemanha nazista, mostrando-nos para onde fomos e com quem e, em razão disto, o que nos aconteceu e aonde chegamos.

Ao que parece a ideia de destruição do mundo comum, da pluralidade humana e de uma escolha por trilhar o caminho do viver entre amigos está em jogo, uma destruição de tudo que há no espaço do 'entre nós', um espaço especialmente privilegiado para vivenciarmos a philia, o mútuo respeito entre iguais, a liberdade, a política. Não queremos 
isso. Condenamos tal opção. Resistimos a trilhar por esta rua de mão única que nos desumaniza, isola, descarta, daí o nosso interesse por estudá-la, compreendê-la e, se possível, transformá-la por atos e palavras em algo novo e melhor de se viver ${ }^{59}$.

Arendt faz uma crítica ao pensamento filosófico construído por Nietzsche no século XIX ao vincular a ideia de deserto a nós, como se o deserto, portanto, o nada e o ninguém, estivessem em nós e não na ausência do 'entre nós'. Segundo a autora não somos do deserto, embora vivamos nele, sendo assim devemos atentar para não nos tornarmos verdadeiros habitantes do deserto passando a nos sentirmos nele como se estivéssemos em casa. Como alguns poucos o fizeram (atentaram a isso), servindo-nos como exemplos, é forçoso dizermos não a tal cenário desertificado sob pena de adentrarmos um estado de desacordo com nós mesmos. E o que é pior nos adaptarmos a isso.

Num posicionamento de criticidade em relação ao niilismo nietzschiano que não vê outra saída a não ser acostumar-se à ideia de um deserto que cresce não apenas no mundo, mas em nós mesmos, Arendt enfatiza a importância de resistir e acredita na possibilidade de transformações do mundo deserto num mundo humano onde temos condições de visualizar alguém e alguma coisa. E tal tarefa parece passar pela esfera da educação. Neste sentido, a questão a ser pensada é que papel a educação pode desempenhar no mundo em face de tal quadro crítico. O caminho parece ser a inserção do novo no mundo, daí o conceito de natalidade em Arendt ser tão importante para nós, assim como o de educação, na medida em que aquele nos é apresentado como sendo a essência deste: "o fato de que seres nascem para o mundo" (ARENDT, 1990: 223) e ambos requererem cuidados, por isso os mais velhos devem assumir a responsabilidade tanto pelo mundo como pelos mais novos.

Como temos percebido tais tarefas (de resistência e transformação) são atreladas às nossas responsabilidades pessoais, políticas e educacionais, que tem haver essencialmente com as escolhas que mostram quem somos no mundo, onde queremos viver e com quem. Estamos com Arendt neste sentido, e a educação assume papel importante nesse trajeto de escolher com quem vamos e para onde, na medida em que é concebida como introdução dos novos no mundo, como formação para a vida pública. Lembrando o exemplo deixado pelos antigos, para o viver entre iguais e amigos (philia), livremente, indicando isso como

\footnotetext{
${ }^{59}$ Arendt chama a nossa atenção para o fato de que alguns não se recusaram à atividade de julgar, assumiram suas respectivas responsabilidades pessoais, na medida em que, como forma de resistência (ação), eles não participaram na esfera política dos regimes totalitários.
} 
algo de melhor para se viver uma melhor vida humana no espaço comum que concebiam como sendo o lugar da vida boa, da vida política.

Manifestamente contrários a essa possível realização de uma melhor vida humana, os movimentos totalitários parecem ter sido a mais adequada forma política de vida no deserto (o nazismo, o seu maior exemplo), cuja principal característica foi terem sido extremamente bem ajustados às condições do deserto. Para Arendt os movimentos totalitários apresentam-se como ameaça a toda e qualquer forma de pluralidade, autoridade e de responsabilidade pelo mundo comum, colocando em risco iminente as duas faculdades humanas que nos permitem transformar pacientemente o deserto, e não a nós mesmos, as faculdades conjugadas da paixão e da ação.

Transformar deserto em mundo humano é algo que julgamos importante, é a escolha por resistirmos aos processos de desertificação, assumirmos nossas responsabilidades e cuidarmos do mundo. Para tanto é preciso ter coragem de agir nele e por amor a ele, um ser que age quando está inserido num universo de condições políticas que revelam a nossa existência plural (pública) e que pode transformar deserto em mundo. Como vimos, o milagre da ação (initium) oferece-nos as melhores possibilidades para romper inesperadamente com a produção de tais processos, podendo ser realizado pelo novo, pelo revolucionário, "só quem é capaz de padecer a paixão de viver sob as condições do deserto pode reunir em si mesmo a coragem que está na base da ação, a coragem de se tornar um ser ativo" (ARENDT, 2008: 267).

Iniciar-se algo no deserto? Só por milagre, mas é possível, e a educação assume papel importante nesse sentido, cabe a ela, e à figura do educador, o papel de contagiar os novos com a possibilidade de realização desse milagre da ação que se dá pelo acolhimento e pela inserção dos novos no mundo. Estes podem ser contagiados com o amor e o cuidado com o mundo, e com as pessoas que nele convivem, e, singularmente, agir e transformar eficazmente por atos e palavras o mundo, se desértico este estiver, ou mesmo conservá-lo, se humano e comum.

Nessa metáfora do deserto Arendt ressalta, por exemplo, que a nossa existência no singular, os oásis (fontes vitais: amizade, amor, arte e filosofia) são as esferas da vida que existem independentemente das condições políticas que revelam nossa existência plural. E que as tempestades de areia delineadas por movimentos totalitários ameaçam os oásis do deserto sem os quais nenhum de nós poderia resistir. Sem a incolumidade desses oásis não 
conseguiríamos respirar. Os oásis não são lugares de relaxamento, mas fontes vitais que nos permitem viver no deserto sem nos reconciliarmos com ele. Caso contrário, os nossos oásis secarão. Escapar do mundo deserto é uma forma menos perigosa e mais sutil de arruinar os oásis do que as tempestades de areia (escapismo). E no afã de escapar levamos as areias do deserto para os oásis.

Cada uma dessas observações apresentadas por Arendt que envolvem aquilo que delineamos ser a metáfora do deserto sugerem caminhos a serem percorridos, conceitos a serem investigados, compreendidos e problematizados. Estas reflexões são importantes e se estendem a duas outras perguntas refletidas pela própria Hannah Arendt no bojo dessa metáfora que liga deserto à ausência de mundo comum (vida pública), e que chama a nossa atenção para o fato de que não nos adaptemos a ele tampouco escapemos, nos esquivemos ou mesmo fujamos dele. Essa é a sua escolha que simbolicamente nos indica possíveis caminhos, servindo-nos como exemplo que nos inspira a criar novas possibilidades.

Primeiramente "Por que existe alguma coisa em vez de nada?" e, em segundo lugar, “Por que existe alguém em vez de ninguém?", questões levantadas por Arendt e que nos são fundamentais no sentido de indicar que temos escolhas e que podemos seguir na esperança de encontrar alguém. A própria forma como a autora nos apontou tais questões parecem nos indicar a possibilidade de afirmar a existência de alguma coisa e de alguém que pode aparecer em algum lugar mesmo em face de tantas perplexidades. Este lugar é o mundo comum, a vida pública e política na qual podemos aparecer como alguém por intermédio de ditos e feitos realizados singularmente no espaço do entre nós.

Pensando em questões ligadas especialmente às nossas crises no mundo moderno (século XX), a pergunta ressaltada por Arendt, e que tanto nos interessa no presente estudo, é “por que existe alguém em vez de ninguém?" e não se “existe alguém?". Assim, se caminhamos num ambiente inóspito e desértico, fazemos isso na esperança de encontrar alguém e de sermos encontrados por alguém. E numa espécie de confiança antecipada partimos da escolha por caminhos que insistem em afirmar que temos possibilidades não apenas de reconhecermos alguém no mundo, como também de sermos reconhecidos como alguém, singularmente, por alguém.

E isso se dá na esfera da vida pública, como diria Arendt, palco de nossas aparições por atos e palavras que nos permitem que encontremos amigos e com isso que nos afastemos de um mundo deserto no qual predomina a solidão e a alienação do mundo e que 
produz o nada e o ninguém visando apenas o seu consumo. E também na qualidade do estar só (solitude), como modo de existência em que estou junto de mim mesmo, nesse diálogo silencioso de mim comigo mesmo, no qual decido com respeito a mim mesmo, inclusive no que tange ao que devo fazer e com quem seguir. E passa pela tarefa educativa, como um imperativo ético, que se relaciona com o novo ao inseri-lo num mundo pelo qual essa responsabilidade assume a forma de autoridade. De certa forma é como se a autoridade de um professor, por exemplo, fosse assentada na responsabilidade que ele assume pelo mundo comum ao inserir os novos nele dizendo-lhes: "Isso é o nosso mundo" (ARENDT, 1990: 239).

Neste sentido, uma educação que esteja comprometida com o mundo humano e comum nesse trajeto de escolher, primeiramente, que vamos com alguém e, em seguida, escolhendo com quem vamos no mundo, não deixa de ser um juízo e uma opção por trilhar o caminho da resistência contra tudo o que amplifica o nada e o ninguém, distanciando-nos da possibilidade de viver num mundo comum pelo qual podemos assumir a responsabilidade assentando a autoridade para dizer o quanto pode nos ser melhor viver junto, entre amigos, ou, estando só, acompanhados de nós mesmos.

Não podemos nos recusar a assumir a responsabilidade por nós mesmos e pelo mundo, tampouco a autoridade que se assenta sobre tal responsabilidade e de tomarmos uma atitude face ao nosso passado, sob pena de deixarmos de lado aquilo que é essencial à atividade educacional "cuja tarefa é sempre abrigar e proteger alguma coisa - a criança contra o mundo, o mundo contra a criança, o novo contra o velho, o velho contra o novo" (ARENDT, 1990: 243). Podemos tomar a obra de Arendt como o próprio exemplo, uma companhia para seguir conosco no mundo, daí recorrermos a conceitos no pensamento político-filosófico arendtiano que nos permitem identificar e afirmar que existe alguma coisa e/ou alguém que, por existir, pode impedir (resistir) a expansão do mundo deserto onde o que prevalece é o nada e o ninguém. E isso certamente está envolto nas ideias de ação e de discurso que nos levam a outras questões cruciais em nossa atualidade, tais como se é possível identificar o que seja uma ação e um discurso em nossos dias que contribua para que isso ocorra? E neste sentido, o que é uma ação, um discurso e como identificá-los e diferenciá-los da não ação e do não discurso, do mero comportamento e da fala vazia? Em suma, quando estamos agindo e quando estamos discursando? Isso revela quem somos? O mundo comum é condição para que isso ocorra? 
São questões que nos levam a refletir sobre essa linha tênue e fronteiriça entre a existência de um mundo comum e plural, no qual podemos realizar ações e discursos desempenhados em benefício de um viver comum, e um mundo isolado, introspectivo e desértico e a educação tem papel importante nesse trajeto de escolher o que e quem nos acompanha (alguém, nossos amigos) no mundo, tendo possibilidade de contribuir contagiando os novos, como formação humana, com o amor e o cuidado com o mundo comum.

O que coloca em questão o próprio papel do educador (sua responsabilidade ética e política) que não possui outra opção senão resistir à expansão de tal ambientação inóspita e desértica $^{60}$ que pode nos levar ao desaparecimento, à insignificância, dificultando ainda mais a nossa percepção sobre o sentido e a tarefa da educação em nossos tempos, na medida em que a concebemos como uma introdução ao mundo (em crise, fora dos eixos), e tornando-a, paradoxalmente, ainda mais importante e significativa de ser pensada, discutida, compreendida e mesmo realizada, na medida em que não desistimos do mundo tampouco dos novos que nele chegam com a possibilidade de transformá-lo em algo melhor de se viver, se ruim ainda estiver. E o momento de crise nos obriga a isso, pois não há outra escolha, como observa Arendt, "o problema da educação no mundo moderno está no fato de, por sua natureza, não poder esta abrir mão nem da autoridade, nem da tradição, e ser obrigada, apesar disso, a caminhar num mundo que não é estruturado nem pela autoridade nem tampouco mantido coeso pela tradição" (1990: 245-6).

É como se caminhássemos com todas as dificuldades num imenso deserto (não estruturado pela autoridade nem mantido coeso pela tradição), estranhando-o, em busca de algo e de alguém, sem desistir, buscando transformá-lo em algo melhor de se viver. E não é uma tarefa fácil. Aliás, ao contrário, muito difícil e pouco provável de ser realizada com êxito. Como diz Arendt, só por milagre, o milagre do novo. Daí a importância do conceito de natalidade e da própria tarefa educativa a cumprir um papel importante nesse sentido, parecendo ser o educador alguém que por definição acredita que o milagre da ação possa irromper no mundo mesmo estando em face de tais aspectos produtores de um imenso deserto a crescer.

\footnotetext{
60 "Em resumo, talvez se possa dizer que "introduzir no mundo" é um "não" qualificado ao não mundo e à situação de abandono." Almeida,Vanessa Sievers de. Educação em Hannah Arendt: entre o mundo deserto e o amor ao mundo.. São Paulo: Cortez, 2011, página 90.
} 
Quem, por exemplo, nos dias atuais vive a experiência de ser professor numa escola pública em nosso país pode descrever com intensa profundidade o que sente, vive e sofre ao adentrar numa sala de aula com a responsabilidade de introduzir os novos num mundo comum que os precede (que lhes é importante e que por isso deve ser cuidado, preservado), mas que fatos e relatos provenientes dos mais diversos meios insistem em dizer, por imagens e palavras, que isso já não é mais possível, dada a quantidade de coisas absurdas que têm ocorrido e vêm sendo realizadas pelo próprio homem em nossa casa que é o mundo. Manifestando com isso a nossa perda da autoridade e de responsabilidade pelo mundo e nos indicando que o que nos resta é nos adaptarmos a tal condição ou então sumir, pois não há o que dizer nem fazer noutro sentido. Como lidar com esse cenário de horrores ocorridos no século passado, por exemplo? Como lidar com os horrores e as perplexidades de hoje? E como introduzir os novos num mundo comum em face de tantas dificuldades, perda de autoridade e de responsabilidade?

Imaginando. Acreditando no milagre da ação. Pensando, debatendo e agindo no mundo talvez possamos encontrar algum caminho. E a indicação para isso pode ser dada por intermédio da educação, da formação humana para o viver comum, mirando exemplos, fragmentos, pérolas que nos deem pistas de outras possibilidades ao estabelecer contato com o novo, o inusitado, o imprevisto em face de tantas perplexidades.

Dilemas e problemas a serem enfrentados por nós no presente, e no próprio mundo, e que passam pelo âmbito da educação na medida em que esta não apenas o reflete, mas também porque tem a possibilidade de acolher, formar e inserir os novos em tal mundo de modo a realizar muitas coisas para cuidá-lo ou mesmo transformá-lo, podendo contar desta forma inclusive com algo, uma espécie de companhia no mundo, nesse trajeto de escolher com quem vamos, que não nos deixa isolados e que pode nos unir em torno de experiências e significações que nos são comuns, oferecendo-nos possibilidades para viver junto, acompanhados por alguém. ${ }^{61}$

\footnotetext{
${ }^{61}$ Não me esqueço de um momento vivido no interior da escola pública, na qual leciono filosofia, onde, numa determinada ocasião, adentrei uma sala de aula e, passados alguns minutos, percebi que um aluno permanecia sentado de costas para mim, ignorando completamente a tudo que se passava. Interrompi a aula e, publicamente, dirige-me a ele dizendo: "Por favor, vire-se, pois quero te ver e quero que você me veja". Ele imediatamente virou-se e começou a acompanhar não somente aquela, mas todas as minhas aulas dali por diante. Ele havia mudado completamente a sua conduta nas aulas até que certo dia, passados mais de quatro meses, observei: "É impressionante como você vem acompanhando bem as nossas aulas de filosofia, como você mudou, cresceu. Como as aulas vêm fazendo sentido para você." E ele, surpreendentemente: "Sabe o que é professor: nunca nenhum professor se preocupou comigo da forma como o senhor se preocupou".
} 
O que nos faz pensar sobre nós mesmos, nossa condição humana, a vida e onde queremos viver, nossas cidades, lugares, coisas, pessoas e mesmo sobre nossas escolhas, juízos, adaptações, fugas, escapismos e quiçá resistências ou até transformações e, em especial, para quem tem de alguma forma sua vida ligada à esfera da educação e à vida pública, ou seja, todos nós (de uma forma ou de outra). Escolhas que vão dizer para onde iremos e com quem. E mais uma vez nos encontramos diante das mesmas perguntas: Com quem vamos no mundo, se é que vamos com alguém? E onde queremos viver?

Na modernidade trilhamos o caminho da introspecção, nele não acreditamos no mundo, no outro, em nada e em ninguém, nem mesmo em nós. Duvidamos de tudo e de todos. Segundo Arendt, um dos fatores que mais teriam contribuído para esse processo de introspecção do sujeito que dá as costas para o mundo, para tudo e para todos, e vê-se diante apenas de si mesmo, fora o advento da dúvida cartesiana. Introspecção, palavra que nos remete ao pensamento cartesiano e que, segundo Arendt, teria contribuído significativamente para o crescente processo de desertificação e para a aparente perda de sentido da política na modernidade, com o predomínio da ausência de mundo e da perda de senso comum. ${ }^{62}$ Numa forma moderna de duvidar que parece traduzir fatores determinantes da modernidade, dentre os quais a própria introspecção, que não acredita no mundo e vê diante de si tão somente um imenso deserto a crescer, não há esperanças, somente desamparo, abandono, desarraigamento, superfluidade, como observa Arendt, no qual o homem vê-se diante de nada e de ninguém a não ser de si mesmo produzindo o nada e o ninguém. Não há diálogo, reflexão, intersubjetividade, troca, vida comum. Duvidamos de tudo, desacreditamos de todos e tão somente somos capazes de enxergar aquilo que nós mesmos produzimos isolados e introspectivamente, um imenso deserto a se expandir que nos faz sumir a nós mesmos diante de nada e de ninguém.

\footnotetext{
${ }^{62}$ Segundo Arendt a universalidade da dúvida cartesiana se funda: no depoimento dos sentidos; no depoimento da razão; no testemunho da fé. Essa dúvida cartesiana reside na perda da evidência que dispensa demonstração, "a inteligibilidade à compreensão humana não constitui demonstração de verdade, tal como a visibilidade não constitui prova de realidade" (ARENDT, 2008, p. 288). É uma dúvida que duvida que exista essa coisa chamada verdade seja pelos sentidos, pela razão ou pela crença. Ser e aparência estão definitivamente separados e, portanto, então tudo deve ser posto em dúvida, inclusive o nosso senso comum. A leitura de um instrumento (o telescópio) havia aparentemente derrotado a mente e os sentidos. A principal característica da dúvida cartesiana: sua universalidade. O fato de que nada, nenhum pensamento ou experiência, escapa da dúvida. Que a verdade se revela por si mesma era o credo comum: à antiguidade pagã e hebraica; à filosofia secular e à cristã. Por isso a nova filosofia moderna voltou-se contra a tradição. Como observa Arendt, o senso comum fora antes aquele sentido através do qual todos os outros, com as suas sensações estritamente privadas, se ajustavam ao mundo comum, tal como a visão ajustava o homem ao mundo visível (comum $=$ o mundo). Na Era Moderna, o senso comum era assim chamado meramente por ser comum a todos (comum = estrutura da mente). Esta transformação do senso comum num senso interior é característica de toda a Era Moderna. E Arendt claramente estabelece uma relação entre tal característica e a alienação do homem em relação ao mundo na modernidade.
} 


\section{CONSIDERAÇÕES FINAIS}

A metáfora do deserto simboliza o desamparo, a falta de esperanças, a rua de mão única que não nos dá direito a escolha, a adaptação a um mundo onde predomina o deserto traduzido numa sociedade de massa que consome o mundo e numa burocracia ideológica e totalitária que nos indica o caminho da desaparição, da insignificância, representando a própria inviabilização das possibilidades de reconhecimento de nossas singularidades, pluralidade humana e viver comum. Noutros termos, o processo de desertificação de coisas e pessoas traz consigo a marca da impossibilidade de sermos alguém no mundo, destrói violentamente a pluralidade humana e coloca em risco a possibilidade do novo.

Faz sumir nós mesmos e o mundo humano que compartilhamos entre nós, deixando-nos muitas vezes deslocados do e no mundo, sem um lar comum, sem um mundo ao qual pertençamos pluralmente e no qual podemos aparecer singularmente e que pode ser traduzido em cidades mortas, destruídas, com suas coisas, pessoas, pensamentos, que tantas faltas nos fazem e que tão importante nos são. E que, de certa forma, o pianista tenta buscar, e retrata com simplicidade e profundeza, ao caminhar por entre escombros de um viver comum, sem desistir, buscando encontrar alguém ou alguma coisa, uma pérola, um fragmento, um vestígio de pertencimento ao mundo (pessoas, objetos, lembranças, histórias, valores) em face do que fora produzido imensamente: nada, ninguém.

Educar em meio à moderna expansão do mundo deserto por amor ao mundo humano e comum. Eis a questão. 


\section{REFERÊNCIAS}

ALMEIDA, Vanessa Sievers de. Educação em Hannah Arendt: entre o mundo deserto e o amor ao mundo. São Paulo: Cortez. 2011.

ARENDT, H. A condição humana. Tradução de Roberto Raposo. Posfácio de Celso Lafer. 10a . Edição. Editora Forense Universitária. Rio de Janeiro. 2008.

A condição humana. Tradução de Roberto Raposo. Revisão técnica e apresentação: Adriano Correia. 11 a . Edição. Editora Forense Universitária. 2010.

- A dignidade da política: ensaios e conferências. Organizador: Antônio Abranches; tradução: Helena Martins e outros. Rio de Janeiro: Relume-Dumará. 1993.

. A Promessa da Política. Organização e introdução de Jerome Kohn. Tradução de Pedro Jorgensen Jr. Revisão técnica de Eduardo Jardim. Editora Difel. Rio de Janeiro. 2008 .

A vida do espírito. Tradução de Antonio Abranches e Helena Martins. Editora Relume Dumará. Rio de Janeiro. 1993.

Compreender: formação, exílio e totalitarismo (ensaios) 1930-54. Tradução Denise Bottman; organização e notas Jerome Kohn. São Paulo: Companhia das Letras; Belo Horizonte: Editora UFMG, 2008.

Entre o passado e o futuro. Tradução de Mauro W. Barbosa. Editora Perspectiva. São Paulo. 1990.

. Origens do Totalitarismo. Tradução de Roberto Raposo. Editora Companhia das Letras. São Paulo. 2007.

Responsabilidade e julgamento. Tradução de Rosaura Einchenberg. Editora Companhia das Letras. São Paulo. 2004.

ARISTÓTELES. Política. Editora Martins Fontes. 2006. .Ética a Nicômaco. Os Pensadores. Abril Cultural.

BACHELARD, Gaston. A poética do espaço. Editora Martins Fontes. 2008. 
BENJAMIN, Walter. Rua de mão única. Obras escolhidas, volume 2. Tradução Rubens Rodrigues Torres Filho e José Carlos Martins Barbosa. Editora Brasiliense. 1987.

BOBBIO, Norberto. O terceiro ausente: ensaios e discursos sobre a paz e a guerra. Tradução Daniela Beccaccia Versiani; organização Pietro Polito. Barueri, São Paulo: Manole. 2009.

CANDIDO, Antonio. O homem dos avessos. In: COUTINHO, E. P. (Org.). Guimarães Rosa. Rio de Janeiro: Civilização Brasileira/Brasília: (Coleção Fortuna Crítica) INL, 1983.

CARVALHO, José Sergio (organizador). Educação, cidadania e direitos humanos. Editora Vozes. 2004.

A Crise na Educação como crise na modernidade. Revista Educação. Especial Hannah Arendt Pensa a Educação. Editora Segmento. São Paulo. 2007.

. Educação e Direitos Humanos: formação de professores e práticas escolares (artigo). Ética e cidadania: construindo valores na escola e na sociedade. Secretaria de Educação Básica, Fundo Nacional de Desenvolvimento da Educação. Brasília: Ministério da Educação. 2007.

CHAUÍ, Marilena de Souza. Introdução à História da Filosofia dos Pré-Socráticos a Aristóteles. Editora Brasiliense. São Paulo. 1994.

Iniciação à filosofia. Volume único. São Paulo: Ática, 2010.

COMPARATO, Fábio Konder. Ética. Companhia das Letras. 2006.

. Afirmação Histórica dos Direitos Humanos - 2010.

CORREIA, Adriano e NASCIMENTO, Mariangela (organizadores). Hannah Arendt: entre o passado e o futuro. Juiz de Fora, Minas Gerais: Editora UFJF. 2008.

COURTINE-DENAMY, Sylvie. O cuidado com o mundo: Diálogo entre Hannah Arendt e alguns de seus contemporâneos. Tradução de Maria Juliana Gambogi Teixeira. Belo Horizonte. Editora UFMG, 2004.

CUSTÓDIO, Crislei de Oliveira. Educação e mundo comum em Hannah Arendt: reflexões e relações em face da crise do mundo moderno. Dissertação de Mestrado em Filosofia da 
Educação na Faculdade de Educação da Universidade de São Paulo. Orientação: José Sérgio Fonseca de Carvalho. São Paulo. 2011.

FINLEY, M. Política no Mundo Antigo. Editora Edições 70. 1997.

FONSECA, Márcio Alves da. Michel Foucault e o direito. 2a Edição. São Paulo: Saraiva. 2012.

FOUCAULT, Michel. O governo de si e dos outros: curso no Collège de France (19821983). Tradução Eduardo Brandão. São Paulo: Editora WMF Martins Fontes. 2010.

JAEGER, Werner Wilhelm. Paidéia: a formação do homem grego. Tradução de Artur M. Parreira. 3ª. Edição. São Paulo. Editora Martins Fontes. 1995.

LAFER, Celso. A reconstrução dos direitos humanos - um diálogo com o pensamento de Hannah Arendt. Companhia das Letras. 1988.

Hannah Arendt: pensamento, persuasão e poder. $2^{\mathrm{a}}$. edição, revista e ampliada. São Paulo: Paz e Terra. 2003.

LEFORT, Claude. A invenção democrática: os limites da dominação totalitária. Tradução Isabel Loureiro, Maria Leonor F. R. Loureiro; apresentação Marilena Chauí. Belo Horizonte: Autêntica Editora, Coleção Invenções Democrática 3, 2011.

LOBATO, Monteiro. Cidades Mortas, São Paulo. Editora Brasiliense.

NUSSBAUM, Martha C.. A fragilidade da bondade: fortuna e ética na tragédia e na filosofia grega. Tradução: Ana Aguiar Cotrim. Editora WMF Martins Fontes. São Paulo, 2009.

Plano Nacional de Educação em Direitos Humanos/Comitê Nacional de Educação em Direitos Humanos. Brasília: Secretaria Especial dos Direitos Humanos, Ministério da Educação, Ministério da Justiça, UNESCO, 2007.

PONTY, Maurice-Merleau. Fenomenologia da Percepção. Martins Fontes. 1999.

Programa Nacional de Direitos Humanos (PNDH-3) / Secretaria de Direitos Humanos da Presidência da República - rev. e atual. - Brasília: SDH/PR, 2010. 
RILKE, Rainer Maria. Cartas a um jovem poeta, tradução de Paulo Rónai, Editora Globo, Rio de Janeiro, 1995.

ROSA, Guimarães. Primeiras Estórias, Editora Nova Fronteira, Rio de Janeiro, 1988.

SILVA, Franklin Leopoldo. O mundo vazio: sobre a ausência da política no mundo contemporâneo. In: Mauricio Tratemberg: uma vida para as ciências humanas. UNESP. 2001.

. Viver Junto. Revista SESC - agosto 2010.

VERNANT, Jean-Pierre. As origens do pensamento grego. Tradução de Ísis Lana Borges. Difusão Europeia do Livro. 1972.

YOUNG-BRUEHL, Elisabeth. Por amor ao mundo: a vida e a obra de Hannah Arendt. Tradução Antônio Trânsito. Revisão técnica Eduardo Jardim de Moraes. Rio de Janeiro: Relume-Dumará. 1997.

ZIZEK, Slavoj. Bem-vindo ao deserto do Real! : cinco ensaios sobre o 11 de Setembro e datas relacionadas. Tradução Paulo Cezar Castanheira. São Paulo: Boitempo Editorial. 2003. 